\title{
Studying Africa
}

\section{A guide to the sources}

\author{
edited by \\ Kristina Rylander
}

translated by

Linda Linnarsson and Andrew Byerley 


\begin{tabular}{|l|}
\hline Indexing terms \\
Africa \\
Reference materials \\
Bibliographies \\
Literature surveys \\
Internet sources \\
Social sciences \\
History \\
Geography \\
Anthropology \\
Education \\
\hline
\end{tabular}

Originally published in Swedish by Nordiska Afrikainstitutet in 2004 as Att studera Afrika. Vägar till källorna.

This translated and revised edition is only available electronically for downloading free of charge, www.nai.uu.se

ISBN 91-7106-564-4

(C) The authors and Nordiska Afrikainstitutet, 2005 


\section{Contents}

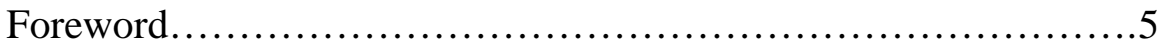

\section{GENERAL INFORMATION SOURCES}

Kristina Rylander

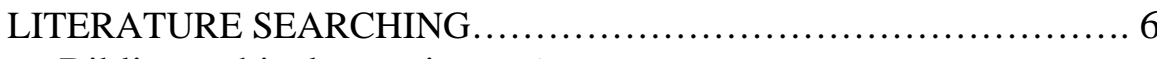

Bibliographical overviews, 6

Current bibliographies, 7

Searching for literature on the Internet, 7

Searching for journal articles, 9

References, 9

Subject related databases, 10

Other web resources, 12

Kristina Rylander

SEARCHING FOR FACTS..........................................13

Country specific information, 13

Subject related information, 16

References, 18

Web resources, 21

Åsa Lund Moberg

AFRICAN INFORMATION ON THE INTERNET

Search services, 22

Link collections, 24

Evaluating the sources, 26

References, 30

Web resources, 30

Birgitte Jansen

JOURNALS.

News services, 31

Development and aid questions, 32

Political and economic journals, 32

Scholarly journals, 33

Older newspapers and journals, 34

References, 34

Databases, 36

Other web resources, 37 
Katarina Hjortsäter

STATISTICS.................................................... 38

Finding statistics, 38

Some statistical sources, 42

References, 55

Web resources, 56

Search terms in NOAK, 57

Peter Kinlund

MAPS

Tourist maps, 59

GeoKatalog, 59

Survey maps, 60

Atlases, 61

Mapping of individual countries, 62

Historical maps, 63

Digital map material, 64

References, 64

Web resources, 67

António Lourenço

OFFICIAL PUBLICATIONS.

Principal types of official publications, 70

Official publications on the Internet, 71

Statistics on the Internet, 72

References, 72

Web resources, 73

\section{LITERATURE SURVEYS}

\section{Tore Linné Eriksen}

HISTORY .75

The history of Africa's history, 75

Atlases and reference books, 76

Overviews, 77

Pre-colonial history, 79

The colonial era and decolonization, 80

Regions and individual countries, 81

References, 86

Tore Linné Eriksen

POLITICS AND ECONOMY....

General overviews, 100

Political parties and democratisation, 102

Africa in the international system, 103 
Gender issues and the conditions of women, 103

Economy, development co-operation, and structural adjustment, 104

Regional and country studies, 106

References, 113

Christer Krokfors

GEOGRAPHY.

General surveys, 130

Introduction to natural geography, 132

Climate, 132

Biogeography, 133

Environment, land and society, 133

Land and livelihood, 134

Population and society, 136

Urbanisation, 137

Economic life and employment, 137

Development geography, 138

References, 139

Knut G. Nustad

CULTURE AND SOCIETY...

Overview literature, 147

Classic monographs, 148

The Manchester School, 149

Systems of thought and world views, 150

Economy and politics, 151

Colonialism and nationalism, 151

Africa and international politics, 152

Representation, 153

References, 154

Ingemar Gustafsson

SCHOOLS AND EDUCATION

The colonial legacy, 162

Liberation movements as milieus for pedagogic innovation, 163

Nation building and economic development, 163

Crises and globalisation, 164

Education of women, 165

The role of development co-operation, 166

Concluding remarks, 166

References, 167

ABOUT THE AUTHORS 


\section{Foreword}

Studying Africa is an introduction to the basic handbooks and standard works on contemporary Africa. The first part of the book is a guide to searching for literature and facts within the field of the social sciences. It deals with bibliographies, databases, reference works, yearbooks, journals, Internet resources, statistics, maps and official publications. Active links to the websites mentioned in the text can be found at the end of each chapter. In the sections entitled "African information on the Internet" and "Statistics", additional links are given within the text itself. The second part of the book consists of introductions to the literature within the subject areas of history, politics, economics, geography, anthropology and education.

Studying Africa addresses students and researchers, although other groups such as teachers, librarians, journalists and personnel involved in development and aid work may also benefit from it. The intention is to give clear and practical guidance to material that is relatively easily accessible.

Studying Africa is a translation from the Swedish Att studera Afrika, which was published in 2004 in a, thoroughly revised, third edition, available both in print and in an online version. Part one of the book was translated by Linda Linnarsson, except for the chapter on maps. Part two and the chapter on maps was translated by Andrew Byerley.

Studying Africa is accessible free from the Nordic Africa Institute's web page, and may be quoted by acknowledging this source. Questions, suggestions and comments may be sent to:

Kristina Rylander

Kristina.Rylander@nai.uu.se 


\section{Literature searching}

\section{Kristina Rylander}

The purpose of this review is to point out some of the fundamental bibliographies and bibliographical databases for African studies. In depth information is given, for example, in Reference guide to Africa by Kagan \& Scheven (1999), The African studies companion by Zell (2003) and Bibliographies \& resource guides in African studies on the Columbia University Library's website. In addition, the quarterly journal, African book publishing record, produces an annual list of recently published bibliographies.

Bibliography - a list of literature within a certain subject area or concerning numerous subject areas... with the task of facilitating access to larger quantities of information to be found on a subject, country, language, etc.

(from: Nationalencyklopedin, translation by Linda Linnarsson)

A (bibliographic) database is a compilation of information that is organized into fields and can be searched logically, with dependable results. Databases may be library catalogues, indexes, or bibliographies, ... the common element is organization and reliable searchability.

(Gretchen Walsh, African Studies Library at Boston University)

\section{Bibliographic overviews}

Bibliographical overviews of countries can be found in various handbook series, examples of which are: African historical dictionaries and the Library of Congress' series of Country studies (see also "Searching for facts”). The World bibliographical series represents 47 African countries. Here, good introductions are given to the literature concerning the respective countries, with examples such as: Zambia by J.Van Donge (2000), Nigeria by R. Bell-Gam (1999) and Cameroun by M.W. DeLancy (1999). There is an abundance of bibliographies covering the various subject fields. Good current examples of these are given in Kagan \& Scheven (1999) and Zell (2003), with continuous updates to be found in the African book publishing record. In general, detailed bibliographies can also be found in many of the monographs dealing with specific countries or subjects.

Larger African bibliographies spanning a long period of time are: the Cumulative bibliography of African studies in five volumes and its followup, the International African bibliography, 1973-1978. These reference sources are built on bibliographical lists compiled by the International African Institute from 1929, and by the School of Oriental and African 
Studies from 1973. For the period after 1978, these lists have been supplemented by the two up-to-date compilations: International African Bibliography and Africa bibliography.

\section{Current bibliographies}

Current bibliographies are those that are issued at regular intervals, e.g. quarterly, and sometimes as annual volumes. These collections usually include references to both books and journal articles, and are generally arranged according to countries and subjects. Bibliographies of this type are helpful in familiarizing oneself with recently published literature. A good example is A current bibliography on African affairs, which always incorporates one or more bibliographical articles relating to special topics over and above those sections dealing with countries and subjects. A further example is the International African bibliography, which is arranged geographically and contains books, journals, documents, articles appearing in collected works, and more. A detailed cumulative index, subdivided into categories such as subject, culture, ethnic groups and languages, comes out annually. The volume entitled Africa bibliography is published once a year in cooperation with the journal, Africa. Here, lists of books, journal articles and collected works can be found. The journal, African affairs (3 issues per year), contains a register of recently released African literature. It also provides a list of articles on Africa published in non-Africanist journals.

National bibliographies are current bibliographies listing all literature published in a particular country. At present 29 of Africa's 53 countries have national bibliographies or similar. These are referred to in the World bibliographical series, mentioned above. Literature published in Africa is also listed in African books in print, with a follow-up in the form of the current African book publishing record.

\section{Searching for literature on the Internet}

Numerous types of databases dealing with literature can be found on the Internet. Bibliographic databases consist of references to books, reports, articles, conference contributions, etc. Here, information is given under each reference about the item's author, title, publisher, year of publication, and more. Sometimes an abstract is also included. Full text databases are sources that provide complete or partial access to the publication itself, besides giving bibliographical information. A third type of database, usually referred to as a hybrid database, is a combined form where full texts are supplied for some documents, while bibliographical details alone are 
provided for others. In A guide to Africa on the Internet there are links which point to the most important databases and library catalogues.

\section{Africa specific databases}

Only a few literary databases exist that concentrate exclusively on Africa. The largest of these by far, is produced by NISC (National Inquiry Services Centre) in South Africa. Concisely referred to as African studies, it is a typical hybrid database. Here the user is able to search simultaneously in the databases of 16 special libraries throughout Africa, Europe and the USA. Amongst its contributors are: the Africa Institute in Pretoria, the School of Oriental and African Studies in London, the African Studies Centre in Leiden and the Nordic Africa Institute in Uppsala. This collective database concentrates on the social sciences and humanities. At present it contains some 800000 references to books, articles, conference contributions and miscellaneous material, a figure that is increasing steadily. Some of the entries are given in full text. African Studies is a commercial database for which a subscription is necessary. In the Nordic regions it is accessible at the Nordic Africa Institute, Uppsala University and at the University of Oslo. Africa.Bib is comprised of two databases, Bibliography of Africana periodical literature and African women's database. It also contains a detailed bibliography of female explorers and missionaries. International documentation network on the Great African Lakes Region is a full text database. Its aim is to collect documents that are hard to come by, and which deal with the current situation and with economic, political and social conditions in the region.

\section{Library databases}

It is also possible to search in individual library catalogues that function as a type of bibliographical database. Besides libraries that specialize in Africa such as, the School of Oriental and African Studies, the Nordic Africa Institute, and the African Studies Centre in Leiden, there are also those that focus on developmental research. Examples of the latter are: the Danish Centre for International Studies and Human Rights in Copenhagen, the British Library for Development Studies, the IMF/World Bank's library, the United Nations' library system, and many university libraries, especially in the USA, with large collections of African literature.

\section{Subject databases}

One category of bibliographic database that cannot be ignored when searching for African literature is the commercial database, which is subject related. Such data collections require subscriptions, although, as a rule, they can be accessed at university and special libraries. They are run by subject experts and are generally of a high standard. The emphasis is placed on journal articles, and the references are nearly always accompanied by abstracts. Some examples of these databases are: Anthropological Index Online, EconLit, ERIC and Sociological Abstracts. A list of subject- 
orientated databases of interest to African studies can be found at the end of this chapter. Sometimes it may be of benefit to do a parallel search in a number of these databases since, while many of them overlap regarding subject content, none of them provides complete coverage of its area of focus.

\section{Searching for journal articles}

References to journal articles can be found in many of the bibliographies already mentioned. However, special journal indexes exist that exclusively list articles. Africa south of the Sahara: Index to periodical literature, for example, has issued four volumes covering the period 1900-1970 along with supplements up to and including 1977. The African Studies Centre (ASC) in Leiden releases a current publications index. This index has been published since 1968, having started out with the title Documentatieblad. In 1994, however, it became known as African Studies Abstracts. In 2003 it ceased to appear as a printed publication and the index now exists as African studies abstracts online, accessible via ASC's website. It covers a large number of journals and collected works. All of the articles are annotated in either English or French. Bibliography of Africana periodical literature - a shared database in Africa.Bib - contains some 50000 references to articles from more than 400 journals concentrating on African studies. The Quarterly index of African periodical literature from the Library of Congress's office in Nairobi has been listing articles, mainly from scholarly journals published in Africa, since 1991. Since 2003 this index has been available in both printed and electronic form on the Nairobi office's website. Interestingly, a comparison of different journal indexes done by the Africana Librarians Council in the USA revealed that the overlap between them is surprisingly small.

\section{References}

Africa bibliography (annual) Compiled by Hector Blackhurst in association with the International African Institute. Manchester: Manchester University Press.

Africa south of the Sahara. Index to periodical literature 1900-1970 (1971). Boston, Mass: Library of Congress. 4 vol.

Africa south of the Sahara. Index to periodical literature, supplement 1971-1977 (1973-1985). Boston, Mass: Library of Congress. 5 vol.

Africa.Bib. Little Rock, Arkansas: Univ. http://www.africabib.org/

African affairs (3 issues/year). [Also electronic] Oxford: Royal African Society. http://afraf.oupjournals.org/ 
The African book publishing record (4 issues/year) Edited by Hans Zell. München: K.G.Saur.

African studies abstracts online. [Electronic] Leiden: African Studies Centre. http://asc.leidenuniv.nl/library/abstracts/asa-online/ [Formerly: African studies abstracts 1994-2002, Documentatieblad 1968-1993.]

Cumulative bibliography of African studies. Author catalogue \& Classified catalogue (1973). Boston, Mass: G.K.Hall. 5 vol.

A current bibliography on African affairs (4 issues/year) Farmingdale, NY: Baywood Publ. Co.

Gorman, G. E. \& J.J. Mills (1987) Guide to current national bibliographies in the Third World. München: Saur. 2.ed.

International African bibliography. Books, articles and papers in African studies. 1973-1978 (1982). London: Mansell.

International African bibliography (4 issues/year) Compiled at the Library School of Oriental and African Studies. London: Mansell.

International documentation network on the Great African Lakes Region. Genève: Réseau

Grands Lacs Africains. http://www.grandslacs.net/home.html

Kagan, A. \& Y. Scheven (1999) Reference guide to Africa. London: Scarecrow Press.

Quarterly index of African periodical literature (4 issues/year). [Also electronic]Nairobi: Library of Congress.

http://lcweb2.loc.gov/misc/qsihome.html [Formerly: Quarterly index to periodical literature - eastern and southern Africa.]

World bibliographical series (1979-2002). Oxford: Clio Press.

Zell, H.M. \& C. Lomer eds. (2000) African books in print. An index by author, subject and title.London: Mansell. 2 vol. 4. ed.

Zell, H.M. (2003) The African studies companion. A guide to information sources. Lochcarron: Hans Zell Publishing Consultants. 3. ed., printed and on-line.

\section{Subject related databases}

These generally require a subscription. A list of freely accessible databases can be reached via the Nordic Africa Institute library's web page under the heading: Bibliographical databases.

\section{Interdisciplinary}

Academic index, 1976-

Francis humanities/social sciences, 1972-

PAIS international (Public Affairs Information Service), 1972-

Social scisearch, 1972- 
Agriculture, rural development of the countryside

AGRIS international, 1975-

CAB Abstracts (Commonwealth Agricultural Bureau), 1972-

\section{Anthropology}

Anthropological Index Online, 1957-

Art, design

Artbibliographies modern, 1974

Children

Child abuse, child welfare \& adoption, 1965-

\section{Demography}

Population index, 1986-2000, free access on the Internet

\section{Dissertations, American and European}

Dissertation abstracts online, 1861-

Ecological and environmental issues, including health and nutrition

Enviroline, 1971-

Environmental bibliography, 1973-

Economy, economic theories, growth, development, planning, etc.

Economic literature index, 1969-

\section{Education, pedagogy}

ERIC (Educational Resources Information Centre), 1966-

\section{Geography, geology and related subjects}

Geobase, 1980-

History and related subjects within the social sciences and humanities Historical abstracts, 1973- 
HIV/AIDS, health, drugs, medicine, sociology

AIDSearch, 1980-, free access on the Internet (registration required)

\section{Humanities}

Arts and humanities search, 1980-

\section{Library and information science}

LISA (Library and Information Science Abstracts), 1969-

\section{Literature, language, folklore}

MLA bibliography (Modern Language Association), 1956-

Linguistics and language behaviour abstracts, 1973-

\section{Music}

RILM abstracts (Repértoire International de Littérature Musicale), 1972-

\section{Psychology and related subjects}

Psycinfo, 1967-

\section{Religion}

Religion index, 1949-1959, 1975-

\section{Sociology and related subjects}

Sociological abstracts, 1963-

\section{Other web resources}

Bibliographies \& resource guides in African studies. New York: Columbia University Library http://www.columbia.edu/cu/lweb/indiv/africa/cuvl/BIB.html

A guide to Africa on the Internet. Libraries and databases. Uppsala: Nordiska Afrikainstitutet http://www.nai.uu.se/links/libraeng.html

Libraries \& archives in Africa. Stanford: University Library http://www-sul.stanford.edu/depts/ssrg/africa/libaf.htm 


\title{
Searching for facts
}

\author{
Kristina Rylander
}

This chapter introduces yearbooks, encyclopedias and other reference material giving access to basic facts and fundamental information concerning particular countries or subjects. In the Nordic Africa Institute's Guide to Africa on the Internet a selection of good links can be found under the headings Country specific information sources and Subject related information sources. Hans Zell's African studies companion (2003) is an extensive guide to many different categories of information sources. This work is available as a printed publication and is also accessible online at the libraries of the Nordic Africa Institute and Uppsala University, among others. The general Internet search services are also useful, especially when searching for specific factual information. More about this can be found in the chapter "African information on the Internet”(p. 20).

\section{Country specific information}

\section{Basic facts}

A good way to begin a search would be to look for brief and basic information on the countries concerned in general reference books such as Nationalencyklopedin or Encyclopedia Britannica. In addition, World factbook and Background notes can be accessed free of charge on the Internet. The former, issued by the CIA, is updated annually, and is also available as a printed publication. Background notes, produced by the U.S. Department of State is updated regularly too. Internet-based information of a brief and topical nature is also offered by Africa Groups of Sweden under Afrikagrupperna: Fakta och nyheter, Sida's Country information Africa and Danida's Landefakta, among others. Country information concentrating on specific problem areas can be found on the websites of various organizations such as WHO, for questions pertaining to health issues, and UNICEF, for questions concerning young people and children. Länder i fickformat is a series of small booklets issued by the Foreign Policy Institute (Utrikespolitiska Institutet) in Stockholm. Each booklet deals with one or two countries and briefly discusses aspects such as their history, geography, politics, people and culture. The world guide: A view from the South is a yearbook that provides clear, concise introductions to countries. Political handbook of the world is a yearbook focusing on political conditions. In this volume, a short background, together with information about the government, constitution and political parties of all the world's nations, is given. Elections in Africa: A data handbook (Nohlen 1999) goes through 
elections and the electoral systems of all of Africa's nations from the time of independence onwards. Elections around the world, available on the Internet, gives insight into political parties, elections and parliaments.

The Corporate Council on Africa in the USA issues an African yearbook. It is succinctly entitled Africa, and contains descriptions of countries, inter alia. With its handy format and affordable price it is also suitable for smaller libraries. The same applies to the Norwegian Council for Africa's most useful yearbook, Afrika-årbok, which contains country profiles, amongst other information.

Somewhat more detailed country information can be found in the Encyclopedia of the world's nations, vol. 1-3 (Kurian 2002). Africa specific encyclopedias also exist, with references to the various nations. The Encyclopedia of Africa south of the Sahara, vol. 1-4 (1997), for instance, contains fairly detailed country descriptions, while the Encyclopedia of African nations and civilizations (2001) is written in a more concise and popular style. As far as printed reference works are concerned, it is always important to pay attention to the year of publication and to supplement this information, if necessary, with fresher facts gathered, for example, from yearbooks or Internet sources.

\section{Country descriptions}

Detailed country descriptions appear in yearbooks concentrating specifically on Africa. Incorporated in Africa south of the Sahara and The Middle East and North Africa, for instance, are country overviews and introductions to geography, contemporary history and economy. These works also incorporate statistical tables dealing with population, production, trade, national accounts, and more. Finally, there is a section with information on the country's government and constitution, its political parties and mass media, schools, transport, defence, and trade and industrial organizations. Considerably smaller is the New African Yearbook, which provides country surveys approximately five pages long. Information, supplemented by maps and tables of facts, is given on political, social and economic development. This volume can be recommended for smaller libraries or school libraries. Of similar size is The Africa review, which gives emphasis to trade and industry, the raw materials market and the economy. Development in North Africa can be followed in the above-mentioned The Middle East and North Africa and in L'annuaire de l'Afrique du Nord, while various aspects of development in the area surrounding the great lakes in Central Africa are discussed in L'Afrique des grands lacs. Detailed information about South Africa can be obtained from the official South African yearbook. This is also available online via the South African government's website under the heading, SA: An overview. Another type of yearbook is Africa contemporary record in which detailed country overviews take the form of accounts of the events and developments in all areas of society for those years represented by the respective volumes. This is a very solid and useful publication. Its release, however, is unfortunately subject to delay, making it necessary to 
look to other sources for more recent developments. One such source is the Annual register, which introduces annual overviews of developments in all countries of the world. In Country profiles issued by The Economist Intelligence Unit (EIU), and which is an annual supplement to their Country reports, an up-to-date overview is given, chiefly of the economy, but also of the political state of affairs within the country. (About EIU see the chapter "Journals", p. 29.)

In addition to these annual publications a few handbook series exist that provide comprehensive information on countries. The Library of Congress Federal Research Division issues the series, Country studies, with North American military personnel as its main target group. Some thirty countries are dealt with in each volume of around 350 pages. These give broad descriptions of all sectors of society, and are most useful as a general information source. They are also available free of charge in an online version, which can be reached, inter alia, under the respective country in the Nordic Africa Institute's Guide to Africa on the Internet: Country specific information sources. Another useful series is African historical dictionaries. These volumes tend to be fairly wide-ranging and, therefore, are not solely of interest to historians. Apart from historical events, entries have also been provided for ethnic groups, geographical names, persons, etc.

For larger country studies in the form of monographs, one can refer to the chapters in Att studera Afrika dealing with subjects such as: "Historie: Regioner og enkeltland" and "Politikk og økonomi: Region- og landstudier". Up to now there is no English translation of these chapters, nevertheless the literature that they refer to is exclusively in English.

\section{News watch}

The most recent data available on countries is to be found in printed or online newspapers and periodicals. A selection of these is introduced in the chapter "Journals" (p. 29). One example is EIU's Country reports which are excellent for following the political development in a country. Keesing's record of world events, based on daily newspapers and other news sources throughout the world, is a current record of the progress of events both internationally and in individual countries. A corresponding synopsis of development on the African continent can be found in Africa research bulletin, which consists of a political and an economic series. These are issued monthly and have a detailed annual index. Up-to-date information can also be sought via the Internet through news bureaus such as AllAfrica, PANAPRESS and South African News Sources, as well as in the national media. These can be reached via the Nordic Africa Institute's Guide to Africa on the Internet under the headings: News agencies, Broadcasting and Country specific information sources. 


\section{Subject related information}

\section{Reference works and yearbooks}

The Encyclopedia of Africa south of the Sahara, vol. 1-4 (1997) and the Encyclopedia of African nations and civilizations (2001) have already been mentioned in the preceding section on country information. In these, there are also articles on different subject areas. The former in particular, is very solid and has a well produced index. The Encyclopedia of Africa nations and civilizations in one volume, contains an abundance of maps, tables of facts, and illustrations, and ought to be useful for students at secondary school level. A guide to African political \& economic development (Arnold 2001) goes through the development of a number of regions during the period 1960 to 2000 in 14 chapters, with headings such as: "Independence struggles and movements", "Regional economic groupings" and "Africa's ethnic diversity". A political chronology of Africa (2001) forms part of the series Political chronologies of the world. This covers development countryby-country from the earliest times, but most importantly, from the colonial era until the present day. Quite a few more reference works focusing on history are discussed in Att studera Afrika, in the chapter "Historie".

The yearbooks Africa south of the Sahara and The Middle East and North Africa begin with background articles on the political and economic development in the area, while Africa contemporary record opens with a number of essays on topical questions.

Afrique politique (formerly Année africaine) incorporates a collection of articles concerning current issues and problems in various African countries. The world guide contains a series of survey articles on population, health, education, environment, trade, etc. The World Bank's World development report, which comes out annually, gives a detailed analysis of economic developments in states throughout the world. Each year, the Human development report, issued by the UN's Development Programme (UNDP), devotes itself to a special theme, for example, "Millennium development goals" (2003). African development report from the African Development Bank also concentrates on an annual theme. The topic for 2002 was "Rural development for poverty reduction in Africa". The last three organizations are also excellent sources for statistical information. Read more about this in the chapter entitled "Statistics" (p.35).

\section{Documentary texts}

Resolutions, treaties and other documents can often be found in full text as appendices to books. Another important source of documents is Africa contemporary record, which has a section made up entirely of texts concerning international relations, constitutional development, and economic and social relationships. Africa research bulletin often reproduces complete or partial documentary texts. In addition, texts of documents are regularly featured in Keesing's record of world events and in the French 
language publication, Afrique contemporaine. Texts of the constitutions of African states can be found in Constitutiones Africae (Reyntjens 1988-), together with an analysis of the text and a description of the historical background of each country. The constitutions themselves, together with their amendments, are published as supplements to the statute books that form part of the Nordic Africa Institute's collection of official publications. Read more about this in the chapter entitled "Official publications" (p. 61). Constitutional developments in each country are followed, with reproductions of statutory texts, in both Africa contemporary record and the Africa research bulletin. The publication, Documents of the African Commission on Human and People's Rights (Murray 2001) contains basic documents, resolutions, bulletins, reports, and more, from 1987, when the commission was established, onwards.

\section{Regional and international organizations}

The Historical dictionary of international organizations in sub-Saharan Africa (DeLancey \& Mays 1994) covers regional and international organizations from the beginning of the $19^{\text {th }}$ century until 1992. A list of acronyms, a chronology, and an extensive bibliography are included. Handbook of regional organizations in sub-Saharan Africa (Söderbaum 1996) gives detailed descriptions of the most important regional organizations as well as particulars of a hundred or so further organizations that were active when the book was written. The Dictionary of human rights advocacy organizations in Africa (Saha 1999) concentrates specifically on human rights and covers the period until 1997.

Since change is an ongoing process, these publications need to be constantly updated with supplementary data. In the yearbooks, Africa south of the Sahara and The Middle East and North Africa, overviews are provided of UN and other international organizations' presence in Africa, as well as of regional African organizations, trade and industrial organizations, and trade unions. FN \& Afrikas utveckling is a Swedish website devoted to the activities in Africa of the UN and its various bodies. Nongovernmental organizations in sub-Saharan Africa is an Internet-based list of organizations concerned with human rights. Links to organizations in Africa can be found in the Nordic Africa Institute's Guide to Africa on the Internet under the headings Research institutes, universities and organizations.

\section{Biographical information}

A succession of biographical reference works has been published, starting at the close of the $19^{\text {th }}$ century and continuing to the present time. Some of these concentrate on individual countries or categories, such as: Biographical dictionary of modern Egypt (Goldschmidt 2000), Africa confidential (Smith 1998) and Political leaders in black Africa (Wiseman 1991). Two historically retrospective reference works worth mentioning are the Dictionary of African historical biography (Lipschutz \& Rasmussen 1986) and Makers of modern Africa. Profiles in history (1996). 
Biographical main entries are also included in African historical dictionaries. A selection of biographies is also available in Pan-Africa history (Sherwood and Adi 2003). A relatively new work in three volumes is African biography (Knight 1998).

Information about people of topical interest can be found in, inter alia, Africa research bulletin and Afrique contemporaine. The contemporary Africa database is a database under construction, produced by The Africa Centre in London. In April 2004 it contained more than 10000 names, which can be searched for alphabetically or according to a particular person's nationality or area of activity.

\section{Ethnic groups and language}

In this section only a small selection of more recent handbooks dealing with this extensive area are mentioned. Ethnologue: Languages of the World is issued by the Summer Institute of Linguistics in the USA, in continuously updated editions. It is available as a printed book, as a CD-ROM, and in a web version. Here, one can search for countries, particular languages or language groups, or alternative language names. The Almanac of peoples and nations (Yakan 1999) begins with a brief survey of African languages and then focuses on ethnic groups, arranged partly under countries and partly in an alphabetical sequence of ethnic groupings. The peoples of Africa: An ethnohistorical dictionary (Olson 1996) is a reference book arranged according to ethnic group names. The Encyclopedia of African peoples is a sister volume to the Encyclopedia of African nations and civilizations. With chapters such as "Peoples of Africa", "Culture and history" and so on, it is presented in an easily accessible format, incorporates maps, tables of facts and illustrations, and is highly suitable for use at secondary school level.

\section{References}

\section{Periodical publications}

Africa (annual). New Caanan: Business Books International for Corporate Council on Africa

Africa south of the Sahara (annual). London. Europa Publications.

Africa review (annual). Saffron Walden, Essex: World Information.

Africa research bulletin. Economic series (12 issues/year). Political series (12 issues /year. Exeter. Africa Research Ltd

Africa contemporary record (annual). London: Collins.

African development report (annual). Abidjan: African Development Bank.

African economic outlook (annual). Paris: OECD/ Abidjan: African Development Bank. 
Afrique contemporaine (6 issues/ year). Paris: La Documentation Française L'Afriques des grandes lacs (annual). Paris: L’Harmattan.

Afrique politique (annual). Paris: Ed. A. Pedone. [Formerly Année africaine]

Annuaire de l'Afrique du Nord (annual). Paris: Edition du CNRS.

Annual register (annual) London: Longman. [Formerly: Annual register of world events.]

Country reports (4 issues/year). London: Economist Intelligence Unit.

Country profiles (annual). London: Economist Intelligence Unit.

Fellesrådets Afrika-Årbok. Oslo: Fellesrådet for Afrika.

Human development report (annual). New York. United Nations Development Programme.

Keesing's record of world events. London: Longman. [Formerly: Keesing's contemporary archives.]

The Middle East and North Africa (annual). London: Europa Publications.

New African yearbook (annual). London: I.C. Publications.

Political handbook of the world (annual). New York: McGraw-Hill.

South Africa yearbook (annual). Pretoria: Government Communication and Information System. [Also online, see below under Web resources]

The world guide. A view from the South (annual). Oxford: New Internationalist. [Formerly: Third world guide.]

World development report (annual). Washington D.C. World Bank.

World fact book (annual). Washington D.C.: Central Intelligence Agency. [Also online. See below under Web resources.]

\section{Other publications}

African historical dictionaries (1974-). Metuchen, N.J.: Scarecrow Press.

Arnold, Guy (2001) A guide to African political \& economic development. London: Fitzroy Dearborn.

DeLancey, Mark W. \& Terry M. Mays (1994) Historical dictionary of international organizations in sub-Saharan Africa. Metuchen, N.J.: Scarecrow.

The Diagram Group (1997) Peoples of Africa, vol. 1-6. New York: Facts on File.

The Diagram Group (2000) Encyclopedia of Africa peoples. New York: Facts on File.

The Diagram Group \& Keith Lye (2001) Encyclopedia of African nations and civilizations. New York: Facts on File.

The Diagram Group (2003) African history on file. New York: Facts on File. Rev. ed.

The Diagram Group (2003) History of Africa. 6 vol. New York: Facts on File. 
Encyclopedia of Africa south of the Sahara, vol. 1-4. (1997). New York: C Scribner's Sons.

Ethnologue. Languages of the world (2003). Dallas, Tex: Summer Institute of Linguistics. 14. ed., printed and CD-ROM [Also online, see below under Web resources.]

Goldschmidt, Arthur (2000) Bibliographical dictionary of modern Egypt. Boulder: Lynne Rienner.

Knight, Virginia Curtin (1998) African biography, vol. 1-3. Detroit: UXL.

Kurian, G.T. (ed.) (2002) Encyclopedia of the world's nations, vol. 1-3. New York: Facts on File.

Library of Congress. Federal Research Div. Country studies. Washington: Library of Congress.

Lipschutz, Mark R. \& R. Kent Rasmussen (1986) History of African historical biography. Berkeley: University of California Press. 2. ed.

Makers of modern Africa. Profiles in history (1996). London: Africa Books. 3.ed.

Murray, Rachel (2001) Documents of the African Commission on Human and People's Rights. Oxford: Hart.

Nohlen, Dieter et al. (ed.) (1999) Elections in Africa. A data handbook. Oxford: Oxford University Press.

Olson, James S. (1996) The peoples of Africa. An ethnohistorical dictionary. London: Greenwood.

A political chronology of Africa (2001). London: Europa Publications.

Reyntjens, F. et al. (ed.) (1988-) Constitutiones Africae, vol. 1-4. Bruxelles: Bruylant.

Rylander, Kristina (ed.) (2004) Att studera Afrika. Vägar till källorna. Uppsala: Nordiska Afrikainstitutet. http://www.nai.uu.se/webbshop/epubl/others/rylander2.pdf

Saha, Santosh C. (1999) Dictionary of human rights advocacy organizations in Africa. Westport, Conn.: Greenwood Press.

Sherwood, Marika \& Hakim Adi (2003) Pan-African history. London: Routledge.

Smith, Patrick (ed.) (1998) Africa confidential. Who's who of southern Africa.

Oxford: Blackwell.

Söderbaum, Frederik (1996) Handbook of regional organizations in Africa. Uppsala: Nordiska Afrikainstitutet.

Utrikespolitiska institutet Länder i fickformat. Stockholm:UI.

Wiseman, John A. (1991) Political leaders in black Africa. A biographical dictionary of the major politicians since independence. Aldershot: Edw. Elgar.

Yakan, Mohammad Z. (1999) Almanac of African peoples and nations. New Brunswick, N.J.: Transaction. 
Zell, Hans (2003) African studies companion. A guide to information sources. Lochcarron: Hans Zell Publishing. 3.ed.

\section{Web resources}

Guide to Africa on the Internet - www.nai.uu.se/links/linkssv.html

Afrikagrupperna (Africa Groups of Sweden). Fakta och nyheter www.afrikagrupperna.se/fakta/afrikafakta.htm

The contemporary Africa database - http://people.africadatabase.org

DANIDA. Landefakta www.um.dk/da/menu/Udenrigspolitik/LandeOgRegioner/Afrika/Landefakta/

Elections around the world - www.electionworld.org/

Ethnologue. Languages of the world - www.ethnologue.com/web.asp

FN \& Afrikas utveckling - www.un.dk/swedish/afrika/index.htm

Government of South Africa. SA. An overview www.gov.za/sa_overview/index.html

Human Rights Library, University of Minnesota. Nongovernmental organizations in sub-Saharan Africa - http://www1.umn.edu/humanrts/africa/toc.htm

Sida. Country information- www.sida.se/Sida/jsp/polopoly.jsp?d=161

US Department of State. Backgrund Notes - www.state.gov/r/pa/ei/bgn/

World factbook - www.odci.gov/cia/publications/factbook/index.html 


\title{
African information on the Internet
}

\author{
Åsa Lund Moberg
}

Although the Internet is often the first stop on the way to finding information nowadays, it also serves as a supplement to other sources. Moreover, a greater quantity of information is being produced locally in Africa today, side by side with material about Africa being generated by international organizations, institutions and sources outside the continent.

Compared with five years ago when only a minority of African countries had local Internet connections, now all capital cities and most of the bigger towns are linked to it. Southern Africa, North Africa and francophone Africa have made the biggest inroads into Internet usage.

Information services, portals and link collections, made available on the Net by libraries and organizations with an African focus, are often effective starting points for locating structured information on Africa. If correctly used, bigger search engines such as Google, also serve to sift out relevant material from the unstructured mass of information that constitutes the Internet.

Finding Internet information that is relevant, current and reliable is tricky, and these sources need to be reviewed and evaluated in exactly the same way as they would be in the case of the printed media. Over and above the usual questions: Who? (Author/Originator), Why? (Purpose) and When? (Is it up-to-date?), as far as sources on the Net are concerned, one can also ask: How? (How did one actually arrive at the source?)

\section{Search services}

Search services on the Net can be broadly divided into two groups: search engines and link catalogues, although these often function as portals nowadays, offering both services simultaneously.

\section{Search engines}

What characterizes search engines such as Google is that web pages' contents (words) are searched for mechanically and assembled in a database. Robots search web pages by scouring the Internet for data through links located on those pages. With searches performed via a form, the search word is matched against a word in the database, which subsequently points to those web pages on which the word is located. All search engines have help pages with tips on how to use the service most effectively. The biggest problem concerns the number of hits that come up. The responses are presented in order of rank, among other things, which is determined by: the 
sequence in which the words appear in the search query, the position of the words on the web page and the number of links there are to the page. Those web pages where the word appears often - in the title and in the web page's Metadata (the information about the web page's author, title, publication date, subject matter, type of material, etc, which is stated in the HTML code) - will occur highest up on the list. The same applies to those web pages to which many other web pages have linked. There are ways, however, to define a search in order to avoid an unwieldy mass of responses.

Question: "How does education in Kenya appear from a gender perspective?" On entering the search words "gender education Kenya”, the result is a response magnitude of 406000 hits. Yet, although the first hits on the list look positive, the sheer volume of the responses makes it difficult to ascertain at a glance which links are most useful. In an advanced search, the inquirer limits the search to those links which appear on the website with .org in the address (the domain). This results in a response range of 98300 hits, confined to information from organizations or websites that have chosen .org as their address. Read more about addresses below under "Reviewing the sources". The first alternatives are promising, with links to: Population Council, UNECA, World Bank, The Maasai Girls Education Fund and UNESCO. However, by limiting the probabilities even further within the advanced search to links in PDF or RTF formats, it becomes possible to pick out information that provides a more detailed answer to the question. PDF or RTF formats are often chosen for presenting reports or similar material that has already been published in printed form.

Some useful tips: Pinpoint relevant material by picking out further search words from the links that come up. For example, adding the word "girls" to the search will result in links to material on basic schooling, and incorporating "higher education" will supply links to information concerning universities. Also, words should be used that say something about the nature of the material being sought. Depending on what one is searching for, words such as: white paper, position paper, statistics, graphs, tables, report, profile, statement, or similar, will limit the number of hits for relevant material. Change .org to .ke in the domain field, and this will attract information published in Kenya, or change the domain to .gov or edu., and data will come up concerning government organizations or public authorities in the United States. Read further about this in the section on addresses in the section on evaluating the sources. Additionally, try to alter the word order of the search query, since the ranking of the hits differs according to the positioning of these words.

The biggest weaknesses of search engines are: that they are based on robots that collect links via other links, that they never cover the entire Internet, and that robots visit websites with varying frequency. Websites of larger organizations and those that are very dynamic - such as sites belonging to news bureaus - are visited more often than more peripheral websites. Google, the most well-used search engine at the moment, has links in its database both to web pages that are visited daily by robots and to those 
that are visited perhaps once every six months. This implies that one should question whether the information one is looking for actually exists in the search engine's database. Since a great deal of information published on the Internet focuses on the USA or West/North, and robots collect links from links, one can also ask how well-represented locally produced information from Africa actually is in search engines. It can also be of benefit to try various search engines as they differ from one another more than one might believe as far as content is concerned. The core in the search engines' databases with links to well-known, bigger websites is the same, but the part of the databases containing links to smaller websites or to occasional web pages, differs substantially. Investigations have shown that when searching for narrower concepts in eight bigger search engines, more than half of the total number of links occurred within a single search engine.

Answers from search engines are never better than the database's contents or the question posed. Search engines function best if one searches for unique concepts or words. If the question has a broad or more general scope the result is usually less satisfying, with lots of irrelevant hits. In the latter case, it is better to use a link catalogue or link collection.

\section{Link catalogues}

Link catalogues such as Yahoo, are services where links have been collected and divided up into subject categories. A good comparison is a library with separate shelves for literature on fish, astronomy, etc. The advantage of using link catalogues is that one avoids a lot of the unnecessary 'junk', which comes up when searching in search engines. Link catalogues also provide a general search function whereby it is possible to search the contents of the link catalogue without having to browse within the specified subject categories. Additionally, the links in these catalogues are often annotated. Under the heading, "Regional”, in link catalogues (Yahoo, among others) links are organized under regions or countries. WoYaa! Africa search, for instance, is a link catalogue that focuses specifically on Africa.

\section{Link collections}

Access to data on Africa can be gained via link collections located on those websites belonging to libraries and organizations with an African focus. One method of finding relevant link collections or links is to ask the question: Who cares about my topic? For information on investments in a particular country, for example, one could probably find links on the website of the Swedish Trade Council or its equivalent. The advantage of using link collections is that their links are subject to quality control. What should be considered when using them, however, is that although a certain level of quality is guaranteed, it is dependent on the editor's knowledge of the subject and on the resources available for keeping the collection updated. It 
should also be noted that sometimes selection criteria differ inexplicably from website to website and that occasionally there is no background information available regarding the criteria.

\section{A guide to Africa on the Internet}

The Nordic Africa Institute offers the link collection, A guide to Africa on the Internet, on its website. This has been developed in order to meet the requirements of quality controlled and structured information sources and databases. The contents are directed towards research with many of the links acting as guides to the respective subject areas. Some of the links, however, have a broader focus than simply research. The division into subject related and country specific headings is an attempt to cater to a diversity of users' needs.

The approximately 700 links, with annotations in English, cover the following areas: Country specific information sources; Subject related information sources; Libraries and databases; Journals and magazines; News agencies and services; Broadcasting; Research institutes, universities and organizations; Internet connectivity in Africa; Other collections of information sources on Africa.

\section{Africa south of the Sahara. Selected Internet resources}

A selection of Internet sources prepared by Karen Fung at the Africa Collection, Hoover Library, Stanford University, for the Information and Communication Technology Group (ICTG), African Studies Association, USA. The links are divided according to regions, countries and subjects, with a search function.

\section{African studies Internet resources}

A compilation of bibliographical sources and research material about Africa created at the African Studies Department of Columbia University Libraries, USA. The links are arranged according to region, country, organization and subject, with a search function. The selection is directed towards research and also contains links to full text documents.

\section{An A-Z of African studies on the Internet}

A link collection compiled by Peter Limb, Africana Library, at the Michigan State University, USA. It also contains links to email lists and discussion groups. The links are arranged according to subject with a search function.

\section{Index on Africa}

A link collection maintained by the Norwegian Council for Africa (NOCA). The links are arranged according to countries and subjects. There are also links to news agencies and there is a search function. 
NIZA links

A link collection focusing on southern Africa from the Netherlands Institute for Southern Africa (NIZA). The links are arranged according to countries and subjects with a search function.

\section{Evaluating the sources}

Internet sources must be critically evaluated in the same way as printed sources. The four principle questions that should be asked at the outset are: Who? Why? When? How? A short explanation of each question follows. This overview is by no means complete and should rather be seen as a suggestion for source critical questions and as a complement to the usual questions concerning the evaluation of printed sources. Many libraries give good guidelines on their home pages on the evaluation of Internet resources. A Google search under "evaluating Internet sources" also yields helpful hits.

Who?

Who is the originator/author of the information? Who publishes the data? What authority does he/she/the organization have? Is any information given about the person or organization?

It is both easy and cheap to publish on the Internet. Moreover, there are no quality controls such as editors or subject specialists at publishing houses, economic resources do not create any obstacles, and information provided by the major established bodies is offered side by side with information from private individuals and organizations with both honourable and obscure intentions. Therefore, it is important to have some idea of who is behind the web pages on the Internet in order to validate their authority and authenticity.

Address: Where is the page published? The web page's address, URL (Universal Resource Locator), is constructed according to the model how://where/what. The address http://www.nai.uu.se/bibl/biblsve.html can be divided up in terms of the pattern illustrated below.

Http states that the document is transported through the Internet with hyper text transfer protocol; www that it is a world wide web-document; nai.uu is the name of the server (sub-domain); .se states that the server is found in Sweden (top domain); /bibl states in which catalogue on the server the web page is found and biblsve.html is the name of the web page itself.

\begin{tabular}{lllll}
\hline $\begin{array}{l}\text { protocol } \\
\text { http://www }\end{array}$ & sub-domain & top-domain & catalogue & file name \\
& .nai.uu & .se & /bibl & /biblsve.html \\
\hline
\end{tabular}


By interpreting the top domain codes it is in most cases possible to establish in which country the web page is published or the type of organization to which it belongs. The code often gives an indication as to whether the originator/author comes from a large organization or connection.

Certain country codes as well as certain generic codes (com, org, net), however, may be purchased. Country codes, such as Niue Island, nu, among others, are popular in Scandinavia.

If the information on the web page does not agree with the address, one can question how reliable the source is as in the case, for example, of a statement from Amnesty international concerning human rights in a particular country, recovered from a page where the address concludes with .com or .net.

Links to lists of top domains - both country codes and generic codes can be found by searching in Google, under "top domains". Services can also be found on the Internet where it is possible to search for those who have registered web addresses. Here information about the addresses, as well as other information, can be found. Links to these can be located via Yahoo's link catalogue under the headings, Computers and Internet/Internet/Directory services/Whois.

Problems can be encountered when applying this section of the source evaluation to information that has been produced locally in Africa. As has been discussed above, there are differences in the way in which infrastructures have taken shape in various parts of the continent and it follows, therefore, that it is not always correct to assume that larger institutions and governments have country codes as top domains and that they exist on a local server. In certain cases, even larger institutions have chosen to place their material on commercial servers outside Africa when local connections between cities, and also between countries, are lacking. Furthermore, space can be limited on a local web server, and while its price can be relatively high locally, a range of cheap or free space is available both in the USA and in Europe. The official website of Togo, for example, www.republicoftogo.com, is registered with a contact address in Paris, and the Nigerian government's official website, www.nopa.net, is registered with its contact addresses in the USA.

Contact: Can one contact the originator? Is there an email address? Does email go to an established institution? Is the email address on the same server as the web page? Is there a postal address and telephone number? Is the author actually attached to the institution/organization as he or she claims?

Sometimes no information exists on the web page as to who is behind the information, especially if the page appears low down on the website. By cutting a web page address section by section one can work one's way up 
the website and see if any information can be found higher up in the hierarchy. For example, in the address http://www.ubos.org/finance/pfab16.xls, the document appears on the web page in Excel format and no link is given to the originator. By taking away the ending, finance/pfab 16.xls, one ends up with the website itself, which turns out to be that of the Ugandan bureau of statistics.

If an email address is mentioned with another server address, one can try to arrive at the server by using the analogy, library@nai.uu.sewww.nai.uu.se. That is to say that the name before @ should be changed to www. Many institutions and organizations provide lists of employees on their websites, making it possible to confirm a person's connection to them in this way.

Regarding contact information on pages produced locally in Africa that refers to free suppliers of email services, this is not necessarily a criterion for the information being unreliable or for an author not being an established authority in her or his field. Moreover, prices for local email services - just as with space on web servers - can be high, and an established free email service abroad can be more stable than a service with a local firm that might perhaps not be operating after a few years.

Furthermore, many institutions in the public sector and, for example, in the educational sector in African countries, do not have the same access to computer resources as do similar institutions in Europe and the USA. Therefore, it is risky to draw conclusions from email addresses as to whether or not a particular person has a connection to an established institution. Should the originator be a researcher or have academic connections, however, this information is likely to be furnished in library catalogues or in databases. The Library of Congress, for instance, has a large collection of African material published by academics.

Why?

Is it an advertisement, propaganda or fact?

In order to be able to evaluate a web page, it needs to be understood in context. Sometimes the aim of the publication is clear, and sometimes it can be difficult to distinguish between facts and opinions. Just as some people publish to inform, others publish to misinform. What has been omitted on a web page is perhaps as important as what has been included.

As far as the websites of international organizations are concerned, it should be very clear what their agendas are. Organizations that deal with human rights do not always highlight the positive aspects of a particular country, while a country's official website, with the intention of attracting investors would be likely to avoid publishing any negative information about that country. A local party might describe a conflict in right-left terms, while another party might describe the same conflict in ethnic terms depending on ideological background and interests. Subjective information on the Internet is an important source in itself, provided one can evaluate it within the context of the purpose for which it was published in the first 
place. It is also important to consider the setting within which the web page was published. Perceptions of the world around us differ, not only from a North-South perspective, but also between poles such as Europe and the USA, usually seen as having the same worldview.

When?

Does the website have a date? How often is the information updated? Is it significant whether the information is old or new?

The frequency with which information on a web page is updated can be a clue as to the size of the resources of the organization/originator. If it is a current topic under discussion, old information can be very misleading.

How?

How did the inquirer arrive at that particular site? What other websites are linked to the web page and to which websites does that page lead in its turn? By following the way in which a website is linked on the Internet it is possible to assess how reputable the sources are. Should an inquirer arrive at a website of an established source, this in itself would be a criterion of quality. With many search services such as Google, one can make use of a search string - link:web page's address - to pick up other links to that web page. For example, link:www.nai.se.

Just as interesting as discovering who else has linked to a particular web page is looking to see which links are displayed on the web page itself. If a topical or controversial issue is being dealt with, and links to established sources within the same subject area are missing, this would certainly be worth questioning. A web page that has links both to and from serious sources must be considered more trustworthy than a website where this is not the case.

\section{Comparing sources}

Although a diversity of sources may be an asset, an over-abundance of information can make it difficult to decide which information is correct. One comes across contradictory data on just about everything.

It is important to compare information from many different sources. Yet, to have located a piece of information in two sources does not necessarily imply that it is accurate, since the authors could have used the same primary source for their data. Thus, the degree to which the information correlates must be checked. If long quotations are cited, are they identical? Are numbers the same down to the decimal point? However, if statistics should differ in various sources, this does not imply that the source is wrong, but could possibly mean that the definitions used in the calculations were different.

It is also important to be aware of the resources behind the information and the primary form of the source. In the case of estimations or statistical calculations, for example, where the source was originally printed and then subsequently published in electronic format, it should be taken into account 
on the one hand that a certain percentage error always exists with material that has been interpreted from a text and then electronically scanned, and on the other, that printed versions of documents are not always identical to their electronic counterparts. Certain illustrated material and some appendices, for example, are left out in electronic publishing. This also applies to material derived from established organizations.

\section{References}

Dahlström, Mats (1997). Webbdokument i blixtbelysning. [Electronic] Borås:

Högskolan i Borås. http://www.adm.hb.se/personal/mad/jonsby2.doc

Gidlöf, Håkan, 2001, "Africa-related information sources", Information

development vol.17:2, pp 115-116.

Jensen, Mike (updated July 2002). The African Internet: A status report.

[Electronic] http://www3.sn.apc.org/africa/afstat.htm

Leth, Göran and Torsten Thurén (2000). Källkritik för Internet. [Electronic]

Stockholm:Styrelsen för psychologisk försvar.

http://www.psycdef.se/bibliotek/doc.asp?FileID=37

\section{Web resources}

A guide to Africa on the Internet. Search engines and directories http://www.nai.uu.se/links/searcgeng.html

A guide to Africa on the Internet. Other collections of information sources on Africa -

http://www.nai.uu.se/links/collecteng.html

Africa south of the Sahara. Selected Internet resources -

http://www-sul.stanford.edu/depts/ssrg/africa/guide.html

African studies Internet resources http://www.columbia.edu/cu/lweb/indiv/africa/cuvl/

An A-Z of African studies on the Internet - http://www.lib.msu.edu/limb/a-z/az.html

Index on Africa - http://wwwafrika.no/index/

NIZA links http://www.niza.nl/search.phtml?search_form=url\&lang=en\&lang_help=en\&nav $=\mathrm{e} 3 \mathrm{~b}$ 


\section{Journals}

\section{Birgitte Jansen}

The Nordic Africa Institute subscribes to more than 1500 periodicals of which approximately 500 are current. An up-to-date list of contemporary journals can be found on the library's home page.

Rapid technological advancement in the area of electronic publishing in recent years has resulted in the full text publication of many important journals in a wide range of databases and on the home pages of numerous publishers. In addition, many African daily papers are published free of charge on the Internet, either in their entirety of in part. Moreover, there is a growing tendency for institutions and organizations to publish newsletters on their websites, or to send them to readers via email. In the list of journal references at the end of this chapter, links are given to the home pages of the respective journals with information about publishers, addresses, prices and more.

A selection of important and noteworthy journals, together with links to databases and full text journals, is given in this chapter.

\section{News services}

Daily newspapers

News should preferably be as current as the day on which it is reported. This accounts for the decline in popularity of printed African daily newspapers, which are being replaced by news reporting on the Internet. A wealth of daily papers and other reporting on politics are published electronically throughout Africa today. Links to African daily papers can be found under the respective countries on the Nordic Africa Institute's website in the link collection, A guide to Africa on the Internet, under the heading, Regional and country specific information sources.

An online daily paper that deserves a special mention is the Mail \& Guardian, which is published in South Africa. It not only reports on current topics concerning southern Africa, but covers the rest of the African continent as well. Each article is published in full text and an article archive from 1994 is available.

Another important news channel is IRIN - Integrated Regional Information Network, which is produced by the UN Office for the Coordination of Humanitarian affairs. IRIN embraces the entire African continent and publishes daily news bulletins, together with a weekly summary of events. Free subscriptions to IRIN are available via email. 


\section{Journals}

As far as the printed media are concerned, two noteworthy journals are Africa Analysis and Africa Confidential. Both are fortnightly publications containing a great deal of useful information. Africa research bulletin consists of two separate series, one political and the other economic, which together provide continuous coverage of the politico-economic situation in Africa. An excellent index to these publications lists back-issues from previous years, which are very useful for reference purposes. The Indian Ocean newsletter gives current information on East Africa, parts of southern Africa and the Indian Ocean islands. The French language Jeune Afrique l'intelligent covers all of Africa, with the main focus on the French-speaking regions. A similar and fairly new printed journal is Journal de l'Afrique en expansion, with a supplement entitled, Economia. Some of the bigger news magazines published in London that are worth mentioning are: New African, Focus on Africa (BBC) and the relatively new, NewsAfrica. Also recommended are Southern Africa report and Southscan, which give up-todate information on the southern African regions.

\section{Development and aid questions}

The following important international journals focusing on development and aid can be singled out from the wide range of similar publications: World development, Development and change and Journal of international development. All three are of a high academic standard and include excellent features on African countries. European journal of development research publishes articles that deal mainly with development research carried out in Europe and in cooperation with European institutions. African rural and urban studies is an Africa specific journal that deserves attention. It highlights agricultural issues and regional and urban planning. Development update is relatively new and is published online by the South Africa National NGO Coalition. This publication focuses on aid, and is issued free of charge, in full text.

\section{Political and economic journals}

The Economist Intelligence Unit's Country report and Country profile have a special position here as they are two of the most important journals subscribed to by the Nordic Africa Institute's library. Country report is a quarterly journal, which incorporates reports from each African country, together with a description of the particular country's political and economic 
situation, a prognosis for future political development and statistical data. Country profile is an annual summary. Subscriptions are available for both the printed and electronic versions of these journals. The electronic editions are supplemented by a monthly update.

Two more economic journals that should be mentioned here are: African business and Marchés tropicaux et mediterranéens. The first focuses on English-speaking countries and the second on francophone Africa. African geopolitics, a new journal, contains interviews with political leaders and articles by experts who give their views on African politics.

\section{Scholarly journals}

Articles of a high academic standard are published in older, well-established journals such as: Africa: Journal of the International African Institute, African affairs, Journal of modern African studies and Journal of southern African studies. First-rate articles are also featured in: Africa today, Africa development/Afrique et développment and Review of African political economy (ROAPE). Also recommended is the Journal of African history, which covers the period from the Stone Age to the present day.

Most of the well-known international, scientific journals, which are Africa specific and of a high calibre, are published in Europe, South Africa and the USA. There are also many lesser-known journals published in Africa, which are of an equally high standard and which are of particular importance for African studies since they reflect the research being carried out in Africa. Although irregular publication, short life spans and marketing weaknesses have been problematic for journals since the 1970's, new technology has meant the there has been a new commitment, in the form of various projects, to the promotion of scientific journals published in Africa.

A successful venture thus far is the database, African Journals online (AJOL), which was established by INASP (International Network for the Availability of Scientific Publications) in 1998, with the help of development support. Its aim is to advance African scientific journals and to strengthen the African publishing sector. The database provides access to tables of contents and abstracts, and offers the possibility of ordering articles online. Another worthwhile undertaking is the African E-journals Project, which cooperates with journal publishers in Africa in working towards increasing the number of African journals presented in large, wellestablished databases.

In recent years, many newer journals, most of them Africa-based, have elected to be published exclusively in electronic format. Some examples of journals available free of charge on the Internet are: African journal in conflict resolution, African studies quarterly and West African review. In addition, a list of some 70 journals, accessible without cahrge, can be found 
in the Nordic Africa Institute's A guide to Africa on the Internet under the heading, Journals and magazines.

\section{Older newspapers and journals}

Older newspapers and journal material are invaluable information sources when it comes to researching the political and social history of Africa. CAMP - Cooperative Africana Microfilm Project commenced as early as in 1963, with the intention of microfilming unique material. Since its inception, an important part of this project has been to collect and microfilm daily newspapers from Africa. African newspapers can be found in AFRINUL - African Newspaper Union List. As a member of CAMP, the Nordic Africa Institute orders microfilm of African daily papers for research purposes through interlibrary loans.

The DISA project - Digital Imaging Project of South Africa is a national project with the aim of collecting journal material from South Africa that documents liberation and anti-apartheid movements in the country during the period 1960-1990, and publishing it in digital form on the Internet. On the DISA project's home page, some forty digitalized journals are listed under the heading, A guide to South Africa's struggle for democracy: Anti-apartheid periodicals 1960-1994.

The recommended journals and information resources mentioned above are only a selection. For further searches for Africa specific journals, the Nordic Africa Institute's online catalogue, NOAK, which also contains indexed articles, is very useful. The bibliographical databases described in the chapter "Literature searching" (p. 5) can also be used for this purpose.

\section{References}

The links refer to the publishers'/journals' home pages, which contain information about the journals, their subject areas, subscription details and prices. The year stated is that in which the journal commenced publication.

Africa. Journal of the International African Institute. London, 1928www.eup.ed.ac.uk/newweb/journals/Africa/index.html

Africa analysis.The fortnightly bulletin on financial and political trends. London, 1986- http://217.199.168.239/

Africa development. A quarterly journal for the Council for the Development of Economic and Social research in Africa $=$ Afrique et développement. Une revue trimestrielle du Conseil pour le développement de la recherche économique et 
sociale en Afrique. Dakar: CODESRIA, 1976-

www.codesria.org/Links/Publications/Journals/africa_development.htm

Africa research bulletin. Economic, financial and technical series. Exeter: Africa Research Ltd., 1965- www.africa-research-bulletin.com/

Africa research bulletin. Political, social and cultural series. Exeter: Africa Research Ltd., 1965- www.africa-research-bulletin.com/

Africa today. Denver, Colo.: Africa Today Ass., 1954- http://iupjournals.org/africa today/ateditors.html

African affairs. Journal of the Royal African Society. London: Oxford Univ. Pr.,1945- http://afraf.oupjournals.org/

African business. London: IC Magazines, 1978www.africasia.com/africanbusiness/index.php

African geopolitics = Géopolitique africaine. Washington, DC: OR.IMA International, 2000- www.african-geopolitics.org/

African journal in conflict resolution [Online]. Umhlanga Rocks, South Africa: ACCORD, 1999- www.accord.org.za/ajcr/intro.htm

African population studies [Online]. Dakar: Union for African Population Studies, 1994-www.uaps.org

African rural and urban studies. East Lansing, Mich.:Michigan State Univ. Pr., 1994 http://africa.msu.edu/afripub.htm

African studies quarterly. The online journal for African studies. Gainsville, Fl., Centre for African studies, 1997- www.africa.ufl.edu/asq/

Country profile / EIU, The Economist Intelligence Unit. London: EIU, 1986 www.eiu.com

Country report / EIU, The Economist Intelligence Unit. London: EIU, 1986www.eiu.com

Development and change. Published on behalf of the Institute of Social Studies, The Hague. Oxford: Blackwell, 1969www.blackwellpublishing.com/journal.asp?ref $=0012-155 \mathrm{X}$

Development update. Quarterly journal of the South African NGO Coalition and INTERFUND [Online]. Braamfontein: Inst.,1997-www.interfund.org.za/

European journal of development research. London: Cass, 1989www.tandf.co.uk/journals/titles/09578811.asp

Focus on Africa. BBC magazine. London: BBC, 1990www.bbc.co.uk/worldservice/africa/features/focus_magazine/index.shtml

Indian Ocean newsletter. Paris Indigo Publ., 1981www.africaintelligence.com/accueil/LOI/p_une_LOI.asp

Jeune Afrique l'intelligent. Paris: Jeune Afrique, 1961www.lintelligent.com/gabarits/accueil_online.asp?pageid=1

Journal de l'Afrique en expansion. Paris: 2003-58 rue de Lisbonne, 75008 Paris, email: gideppe@gofornet.com 
Journal of African history. Cambridge: Cambridge Univ. Pr., 1960http://titles.cambridge.org/journals/journal_catalogue.asp?mnemonic=AFH

Journal of international development. Oxford, 1988www.wileyeurope.com/WileyCDA/WileyTitle/productCd-JID.html

Journal of modern African studies. A quarterly survey of politics, economics \& related topics in contemporary Africa. Cambridge Univ. Pr., 1963http://titles.cambridge.org.journals/journal catalogue.asp?historylinks=ALPHA\& mnemmonic $=\mathrm{MOA}$

Journal of Southern African studies. London: Oxford Univ Pr.,1974www.tandf.co.uk/journals/carfax/03057070.html

Mail \& Guardian. Johannesburg: M\&G Media, 1995 www.mg.co.za

Marchés tropicaux et méditerranéens. L'hebdomadaire de l'Afrique et de l'Ocean Indien. Paris: Marchés tropicaux et méditerranéens, 1958- www.moreaux,fr/

New African. London: IC Magazines, 1978www.africasia.com/newafrican/index.php

NewsAfrica. The weekly news magazine for Africa's millennium. London: NewsAfrica, 2000-www.newsafrica.net/

Review of African political economy. Sheffield: ROAPE, 1974www.tandf.co.uk/journals/carfax/03056244.htm

Southern Africa report. Johannesburg: Southern Africa report ass., 1983-P.O. Box 261579, Excom 2023, South Africa

Southscan. A bulletin of Southern African affairs. London:Southscan, 1986 http://southscan.gn.apc.org/

West Africa review [Online]. S.l.:Africa Resource Centre, 1999www.westafricareview.com/war/

World development. The multidisciplinary international journal devoted to the study and promotion of world development. Oxford: Pergammon, 1973www.elsevier.com/locate/worlddev

\section{Databases}

African E-journals Project www.jsp.msu.edu/AfricanStudies/AEJP/projejournal.htm

African Journals Online (AJOL) www.ajol.info/

African Newspapers Union List (AFRINUL) http://afrinul.crl.edu/search-engine/

A guide to South Africa's struggle for democracy. Anti-apartheid periodicals 19601994 http://disa.nu.ac.za/DisaEad.htm

IRIN- Integrated Regional Information Network www.irinnews.org/frontpage.asp 


\section{Other web resources}

CAMP - Cooperative Africana Microfilm Project www.crl.edu/areastudies/CAMP/index.htm

DISA - Digital Imaging Project of South Africa - http://disa.nu.ac.za/

A guide to Africa on the Internet www.nai.uu.se/links/newspapereng.htm 1

NOAK - The Nordic Africa Institute's online catalogue - http://noak.nai.uu.se/F/

The Nordic Africa Institute's library. Newspapers and journals www.nai.uu.se/biblsve.html 


\section{Statistics}

\section{Katarina Hjortsäter ${ }^{1}$}

Statistics are numerical indicators describing a phenomenon or an activity. Through statistical data it is possible to gain insight into the way in which societies operate. Statistical information is important both as a component in published documents and as a foundation for studying and research. Statistics concerning population, education, employment, salaries, prices, interest rates, imports, exports, production, housing and health, for example, reflect the social and economic conditions of a particular country. Nowadays, statistical data is obtainable in both printed and electronic form. It can generally be classified into two groups based on the information sources, namely, national and international statistics.

\section{Finding statistics}

\section{National statistics}

National statistics refer to statistical data collected from national sources. This is statistical information produced by governmental authorities with the responsibility of collecting and coordinating a county's statistics at a national level. The central statistical bureaus of individual countries are the primary producers of national statistics. These are agencies primarily entrusted with the task of determining and organizing a government's statistical production, and for making the figures accessible. Most African countries today have statistical bureaus. Other important providers of national statistics are central and commercial banks, which compile and report the economic statistics of a country. Also considered to be producers of national statistics are non-governmental organizations, research institutions, and the publications of individual researchers in scientific journals and in the rest of the press. National statistics, in other words, describe the activities of a particular nation. This is detailed information that usually exists on a regional level. What can be problematic concerning these types of statistics, however, is that they are often presented in the national language of the country, which leads to difficulties for those not familiar with it.

\footnotetext{
${ }^{1}$ This chapter has been significantly enlarged compared with that of the printed version of the Swedish original, Att studera Afrika
} 


\section{International statistics}

International statistics, being taken from international sources, often appear in English. These sources are organizations such as the World Bank, the International Monetary Fund and other bodies within the UN system along with several organizations, which both produce their own statistical data as well as publishing statistics from statistical bureaus of individual countries. International statistics are not as detailed as national statistics, although they serve a useful purpose when comparisons are made between countries.

Both types of statistics have advantages and disadvantages. It is seldom sufficient to make use of national statistics alone, especially when making comparisons. National statistics in Africa, for example, are still in the process of being built up, and as a result, have their flaws. Whether statistical information will actually be found in the national sources can also depend on the political situation in the country. Statistics on AIDS, for instance, were not available from South Africa's central statistical bureau for some time, presumably on account of this being a politically loaded issue in that country. It was possible to obtain such statistical data on South Africa, however, through international organizations such as UN bodies, WHO and UNAIDS. Thus, international statistics may act as a supplement to national statistical information.

Statistics in printed and electronic form and via the Internet

Nowadays national and international statistics are published both electronically and in print. Printed publications mainly take the form of handbooks of various types such as yearbooks, bank reports, periodicals, official publications and other so-called numerical publications from international organizations. However, statistics also occur in works that are not exclusively devoted to statistical material, which is why it can be rewarding to read a wide variety of publications. A great deal of national and international statistical information can be found in printed form at the Nordic Africa Institute's library. This can be searched for via the library catalogue, NOAK. (A list of useful search words appears at the end of this chapter.) Of particular note is the library's large collection of official publications that incorporates various sorts of national statistics. This material is described in more detail in the chapter "Official publications" (p. 61). A variety of printed publications that include statistics are mainly to be found in larger libraries and in special libraries such as the library of Statistics Sweden (Statistiska centralbyrån, SCB). SCB's collection consists of numerical publications from most of the countries in the world and from some 50 international organizations. Statistics from African countries are mostly presented in yearbooks, and in company and population censuses.

The advancement of information technology has given us statistical data in electronic form, which offers many advantages. Most importantly, information in ever-increasing quantities can easily be obtained from 
databases and via the Internet. Moreover, technological progress has influenced the production of statistics by contributing to the faster and more efficient storing, processing and transmission of larger quantities of data. Users are easily able to customize their own diagrams, tables and maps when statistics are stored in databases, which makes it possible to link and match them. Larger libraries generally, and special libraries such as SCB particularly, provide access to statistical, reference and journal and article databases, which are useful when searching for statistical information.

Both national and international statistics published in databases or other formats are available on the Internet today and can be downloaded. Via their web pages, libraries, research institutes and international organizations make it possible for users to search for references in databases/library catalogues and in link collections with links to web pages containing statistical material. Unfortunately, Internet databases are not always accessible to everyone free of charge, although larger libraries usually enable users to access these databases by agreement with the suppliers. One can naturally choose to search for statistics by going directly to a particular country's central statistical bureau or its equivalent for national statistics, or straight to the web pages of international organizations. These web sites are often extensive and comprehensive. This makes finding relevant information difficult, which is why the search functions on these sites are invaluable aids.

Although most African countries have national statistical bureaus, not all of them have their own web pages yet. Links to national statistical sources such as statistics bureaus and central banks are listed on the Nordic Africa Institute's website in the link collection A Guide to Africa on the Internet, under the heading, Country specific information sources. Links to further statistical sources on the Internet, such as SCB and Statistics Finland (WebStat), can be found under the heading Subject related information sources. The library catalogue, NOAK, can also be found on this website.

SCB has a link collection on their website that functions as a guide to international and global statistics. Links to statistics producers in different countries and to a selection of international organizations of interest from a statistical point of view, have been assembled here, and are categorized according to continent, country, organization and subject. Another excellent statistical source on the Internet is WebStat, which is Finland's equivalent of SCB. WebStat is a database of statistical sources compiled and maintained by the Library of Statistics Finland. This material has been classified according to subject area and country and is easy to find. The search result incorporates a description of the source and a further link to the electronic information.

Free text searching using Internet search engines can have the additional advantage of yielding useful hits that one might not have considered previously. Statistical tables and diagrams are generally presented as PDF, Excel and PowerPoint files, formats in which it is possible to carry out searches through bigger search engines such as Google 
and Yahoo!. It is always important to use several search engines since their indexes contain different web pages that do not all give the same results for a search. The disadvantage of using search engines on the Internet, however, is that it can be difficult to put together a sufficiently specific or effective search string of keywords in order to retrieve relevant material. Free text searching on the Internet is not a precision instrument. A search can result in so many hits that it becomes difficult to choose between them. An abundance of web pages might be supplied in response to a search, although the information contained in them is often the same data collected from the same sources many times over. All information retrieved from the Internet, and especially statistical facts, must be subjected to quality control.

\section{Quality control}

Quality control is important irrespective of whether one uses printed or electronic sources. As far as quality control of statistics is concerned, one ought to give particular thought to the number of intermediaries between the source/producer and the publisher of the data. It is best to gather information directly from the primary source - the body that collects, compiles and produces the statistical information. The body that only publishes statistical data gathered and compiled by some other body or agency is a secondary source. It is always good to know how many intermediaries there are, the principle being: the fewer intermediaries, the better. Moreover, when tables are presented, definitions of the concepts and explanations used should accompany them, or information on finding out about the tables and concepts used. More about what one should think about regarding quality control in general, can be found in the chapter entitled "African Information on the Internet” (p. 20ff), and about statistics in particular, in Swedish, on SCB's home page, under the heading, Statistikskolan.

Statistics can never give a completely accurate picture, but tend rather to represent a simplified interpretation of reality. Since official statistical data are estimated, and are often based on a representative selection, selection failure can occur. In some cases, however, statistics are built on total counts. In addition, it is not always possible to compare information from different countries or points in time, on account of differences in definitions and measuring procedures. Statistics can also be misleading for other reasons such as, losses, incorrect responses or failures in the work process. The situation within a particular country can also influence whether certain statistics will be found, as with the above-mentioned example of AIDS in South Africa. Statistics on AIDS in South Africa, acquired through international organizations, comprise administrative data, assembled from clinics. In many instances this can be the most reliable information, it being difficult to collect this type of statistical data from questionnaires. Therefore one has to be aware that the statistics only relate to those of the country's inhabitants who have sought care. The section of the population suffering from AIDS who have not sought care, on the other hand, can only be estimated. 


\section{Some statistical sources}

\section{Handbooks}

Printed publications, such as handbooks that contain statistics, can nowadays be searched for in various library catalogues on the Web, among them, the Nordic Africa Institute's library catalogue, NOAK, and SCB's library catalogue. Handbooks of special interest when looking for statistics are annuals such as, The Africa review, Africa south of the Sahara and The Middle East and North Africa, and journals like EIU country report and EIU country profile. These incorporate all statistical surveys for economic and social statistics, country-by-country.

Africa at a glance: Facts and figures 2001/2002 is the eleventh edition of a handbook published since 1970, by the Africa Institute of South Africa (Pretoria). This contains basic facts, social, economic and political statistics, presented in clear tables. Sources for numerical data are, inter alia, the World Bank, various UN bodies, OECD, FAO, Economist Intelligence Unit, African Development Bank and other sources such as the monthly, Africa research bulletin. These handbooks are recommended for public libraries as well as for those specializing in African collections.

Although Africa: A publication of the Corporate Council on Africa and Business Books International, is a handbook that does not contain large quantities of statistics, it is, nevertheless, worth mentioning in this context as it lists addresses, telephone and fax numbers, as well as email and web addresses (where available) to statistical bureaus in 47 African countries. This publication, along with the yearbooks, is described in more detail in the chapter "Searching for facts" (p. 12ff) and EIU in the chapter "Journals" (p. 29)

\section{Organizations}

AFRISTAT: Observatoire Economique et Statistique d'Afrique Subsaharienne is an organization whose goal is to support the development of economic, social and environmental statistics in the membership countries. The organization assists the national statistical bureaus in their work and acts towards furthering regional and economic integration, which, in turn, results in conformity and statistical data that is easier to apply when making comparisons. National statistics for 18 countries mainly in west and central Africa can be found on AFRISTAT's website.

\begin{tabular}{lll}
$\begin{array}{l}\text { Databases / } \\
\text { Link collections }\end{array}$ & Web / Format & Accessibility \\
AFRISTAT & Yes. HTML & Free \\
\hline
\end{tabular}

Source: AFRISTAT, http://www.afristat.org/, March 2004.

African Development Bank Group (ADB Group) is made up of the African Development Fund (ADF) and the Nigerian Trust Fund (NTF). This is the 
principle institution in Africa working with financial development, whose goal is to fight poverty and improve living conditions by promoting social and economic growth. ADB issues several publications containing statistical information. The ADB Group's yearbook, African development report, incorporates statistics of economic and social conditions. Compendium of statistics on bank group operations presents various bank activities such as loans, as well as giving country-by-country accounts of exchange rates. Selected statistics on African countries contains comparable statistics listed according to country, and time series data that is country specific and concerns all of the countries on the African continent. Gender, poverty and environmental indicators on African countries is released every other year and furnishes both comparative statistics by country, as well as information on gender, environment, living conditions and poverty in Africa, which is country specific. This publication is also a follow-up to the United Nations Millennium Declaration's Millennium Development Goals. ADB statistics pocketbook summarizes different economic and social information relating to the membership countries and ADB's activities. Most of the information has been taken from the publications mentioned above. Comparisons of basic facts on African countries are presented in Basic indicators on African countries. All these publications and much more can be found on ADB's web page. OECD has been issuing African Economic Outlook in collaboration with ADB, since 2002. This illustrates African economies from a global perspective and contains an index with statistics.

\begin{tabular}{|c|c|c|}
\hline Printed publications & Publication & Web / Format \\
\hline $\begin{array}{l}\text { African development } \\
\text { report }\end{array}$ & 1 issue/year & Yes, partly PDF \\
\hline $\begin{array}{l}\text { Compendium of } \\
\text { statistics on bank } \\
\text { group operations }\end{array}$ & 1 issue/year & Yes. PDF \\
\hline $\begin{array}{l}\text { Selected statistics on } \\
\text { African countries }\end{array}$ & 1 issue/year & Yes. PDF \\
\hline $\begin{array}{l}\text { Gender, poverty and } \\
\text { environmental } \\
\text { indicators on African } \\
\text { countries }\end{array}$ & $\begin{array}{l}1 \text { issue, } \\
\text { alternate } \\
\text { years }\end{array}$ & Yes.PDF \\
\hline $\begin{array}{l}\text { ADB statistics } \\
\text { pocketbook }\end{array}$ & 1 issue/year & Yes PDF \\
\hline $\begin{array}{l}\text { Basic indicators on } \\
\text { African countries }\end{array}$ & $\begin{array}{l}\text { Information } \\
\text { missing }\end{array}$ & Yes. HTML \\
\hline $\begin{array}{l}\text { African conomic } \\
\text { outlook }\end{array}$ & 1 issue/year & No \\
\hline
\end{tabular}

Source: ADB, http://www.afdb.org/, March 2004.

Bank for International Settlements (BIS), is an international organization, which works towards cooperation between central banks and other bureaus for monetary and financial stability. BIS publishes statistics concerning the 
international banking and finance market on its website. Several publications are also available for downloading, amongst them, BIS quarterly review, which includes an index of statistical data. Also listed here are central banks throughout the world, with links to their respective websites.

\begin{tabular}{lll} 
Printed publications & Publication & Web / Format \\
BIS quarterly review & 4 & Yes. PDF \\
& issues/year & \\
\hline
\end{tabular}

Source. BIS, http://www.bis.org/, March 2004.

Organization for Economic Co-operation and Development (OECD) collects statistics on economic and social development. The statistics come from the statistical bureaus in the membership countries. A significant amount of statistical information can be accessed via the organization's website. Via the link Statistics, the web page Statistics portal can be reached, where one can find: statistics published by OECD (classified according to subject), Frequently requested statistics, The statistics brief, The statistics newsletter, as well as further links to other statistical sources. OECD issues many printed publications, among them, Geographical distribution of financial flows to aid recipients in which information can be found on aid and assistance to developing countries. Information can also be found at SourceOECD, OECD's online library, where it is possible to search in various statistical databases. In spite of annually released reports from different international organizations, studies are seldom done where the nations are compared country-by-country with the focus solely on Africa. The OECD Development Centre and the African Development Bank released a new study, African Economic Outlook in 2002. This gives a broad overview of the economic conditions on the continent. The goal is to review the current situation and the short-term development in selected African countries every year, as seen from a global perspective.

$\begin{array}{lll}\begin{array}{l}\text { Printed publications } \\ \text { The statistics brief }\end{array} & \begin{array}{l}\text { Publication } \\ \text { Numerous } \\ \text { iss./year }\end{array} & \begin{array}{l}\text { Web/Format } \\ \text { Yes. PDF }\end{array} \\ \begin{array}{l}\text { The statistics } \\ \text { newsletter }\end{array} & \text { Yissues/year } \\ \begin{array}{l}\text { Frequently requested } \\ \text { statistics }\end{array} & \text { Irregular } & \text { Yes. PDF } \\ \begin{array}{l}\text { Geographical } \\ \text { distribution of } \\ \text { financialflows to aid } \\ \text { recipients }\end{array} & 1 \text { issue/year } & \text { XLS } \\ \begin{array}{l}\text { African economic } \\ \text { outlook }\end{array} & & \text { No }\end{array}$




\begin{tabular}{lll}
$\begin{array}{l}\text { Databases/Link } \\
\text { collections }\end{array}$ & Web/Format & Accessibility \\
Statistics portal & Yes. HTML & Free \\
SourceOECD & Yes. Database & License \\
\hline
\end{tabular}

Source: OECD, http://www.oecd.org/, March 2004.

OECD and BIS, together with the World Bank and the International Monetary Fund (presented later in the chapter) have combined their respective statistical information concerning developing counties' foreign debt on one common web page, Joint BIS-IMF-OECD-World Bank statistics on external debt. There are tables for downloading as PDF and Excel files. A free database, Debt/o, has been created with information from and including 1990.

\begin{tabular}{lll} 
Databases / & Web / Format & Accessibility \\
Link collections & Yes. Database & Free \\
\hline Debt/o &
\end{tabular}

Source: BIS-IMF-OECD-WORLD Bank, http://www1.oecd.org/document/5/0,en_2825_495602_1895813_1_1_1_1,00.html,March 2004.

\section{The UN system}

Statistics are both produced and published within the UN and the various bodies connected to it. The United Nations Statistics Division (UNSD) has been issuing the Statistical yearbook and the Demographic yearbook since 1949. The first publication covers a ten-year period and contains statistical data concerning national accounts and finances, labour, salaries, prices, trade, agriculture, industry, communication and transport, tourism, environment, energy, and more. The latter publication includes statistics relating to population structure and size, fertility, mortality, marriage and divorce. Here one can find a collection of population and housing censuses along with other investigations produced by national central statistical bureaus. Freely accessible statistical data on UNSD's website can be obtained from the databases: The millennium indicators database, which supplies 48 country-by-country tables, of social and economic conditions, and The social indicators, which gives access to statistics concerning population, housing, health, education, income, economic activity, unemployment, reading and writing skills, access to water and sanitation, and more. Further databases dealing with subjects within the social and economic fields exist, although subscriptions are required for these. 


\begin{tabular}{|c|c|c|}
\hline $\begin{array}{l}\text { Printed } \\
\text { publications }\end{array}$ & Publication & Web / Format \\
\hline $\begin{array}{l}\text { Statistical } \\
\text { yearbook }\end{array}$ & 1 issue/year & No \\
\hline $\begin{array}{l}\text { Demographic } \\
\text { yearbook }\end{array}$ & 1 issue/year & No \\
\hline Databases / & Web / Format & Accessibility \\
\hline $\begin{array}{l}\text { The millennium } \\
\text { indicators } \\
\text { database }\end{array}$ & Yes. Database & Free \\
\hline $\begin{array}{l}\text { The social } \\
\text { indicators }\end{array}$ & Yes. HTML & Free \\
\hline
\end{tabular}

United Nations Economic Commission for Africa (UNECA) works with regional integration to promote international cooperation for Africa's economic and social development. ECA compiles and issues a sequence of different publications containing statistics. Several of these take the form of series, such as the annually published Economic report on Africa, whose later issues are available on ECA's website. Economic and social development is also analyzed in the yearbook, Economic and social survey of Africa. Another important publication is the African statistical yearbook, which contains statistical data for ECA's membership countries, also presented according to region. African economic indicators summarizes demographic, social and economic trends in Africa and functions as a supplement to the yearbook. Unfortunately the publication of the three last mentioned volumes has tended to limp along during recent years. Newer publications dealing with subjects such as demography, population, gender, agriculture and the environment, which include statistical information, are available for downloading on ECA's website.

Printed publications
Economic report on
Africa
Economic and social
survey of Africa
African statistical
yearbook
African socio-
economic indicators

$\begin{array}{ll}\begin{array}{l}\text { Publication } \\ 1 \text { issue/year }\end{array} & \begin{array}{l}\text { Web / Format } \\ \text { Yes. PDF }\end{array} \\ 1 \text { issue/year } & \text { No } \\ 1 \text { issue/year } & \text { No } \\ 1 \text { issue/year } & \text { No }\end{array}$

Source: UNECA, http://www.uneca.org/, March 2004. 
United Nations Conference on Trade and Development (UNCTAD), works towards the integration of developing countries in the world economy and deals with the areas of trade and development, together with the closely related areas of finance, technology, investment and sustained development. UNCTAD issues statistical publications such as the Handbook of statistics, World investment directory, the Handbook of world mineral trade statistics and the Commodity price bulletin. Available free on the website, under the heading UNCTAD statistics in brief, are tables listing the most frequently requested statistics produced by UNCTAD. More detailed information can be found in the following online databases: UNCTAD handbook of statistics online, which offers time series of economic data and development indicators from 1950 onwards, and covers more than 190 countries and 50 economic or trade groups, Commodity price bulletin online, which provides indexes and trade prices since 1960, UNCTAD-TRAINS (TRade Analysis and INformation system), which covers trade and imports in around 130 countries, and Foreign direct investment database (FDI) presenting the share market and international investment in 196 economies.

\begin{tabular}{|c|c|c|}
\hline $\begin{array}{l}\text { Printed publications } \\
\text { Handbook of statistics }\end{array}$ & $\begin{array}{l}\text { Publication } \\
1 \text { issue/year }\end{array}$ & $\begin{array}{l}\text { Web/Format } \\
\text { Yes. } \\
\text { Registration }\end{array}$ \\
\hline $\begin{array}{l}\text { World investment } \\
\text { directory }\end{array}$ & Irregular & Yes. PDF \\
\hline $\begin{array}{l}\text { Handbook of world } \\
\text { mineral trade statistics }\end{array}$ & Irregular & No \\
\hline $\begin{array}{l}\text { Commodity price } \\
\text { bulletin }\end{array}$ & $\begin{array}{l}1 \text { issue/ } \\
\text { month }\end{array}$ & No \\
\hline $\begin{array}{l}\text { Databases / } \\
\text { Link collections }\end{array}$ & Web/Format & Accessibility \\
\hline $\begin{array}{l}\text { UNCTAD statistics in } \\
\text { brief }\end{array}$ & Yes.HTML & Free \\
\hline $\begin{array}{l}\text { UNCTAD handbook of } \\
\text { statistics online }\end{array}$ & Yes. Database & $\begin{array}{l}\text { Free. } \\
\text { Registration }\end{array}$ \\
\hline $\begin{array}{l}\text { Commodity price } \\
\text { bulletin online }\end{array}$ & Yes. Database & $\begin{array}{l}\text { Free. } \\
\text { Registration }\end{array}$ \\
\hline UNCTAD-TRAINS & Yes. Database & Free \\
\hline $\begin{array}{l}\text { Foreign direct } \\
\text { investment database }\end{array}$ & Yes. Database & $\begin{array}{l}\text { Free. } \\
\text { Registration }\end{array}$ \\
\hline
\end{tabular}

Source: UNCTAD, http://www.unctad.org/, March 2004.

Food and Agriculture Organization of the United Nations (FAO) is an organization that works to fight starvation and malnutrition and to improve the standard of foodstuffs. The organization also assists its member countries with sustained development within the agricultural sector. FAO issues a large number of titles every year, which contain statistical 
information furnished, for example, in yearbooks, all with the title FAO yearbook. There are many excellent statistical databases to be found on FAO's website, among them the comprehensive FAOSTAT, which offers information about agriculture, food supply, fishing, forestry and population, inter alia. The database contains more than 1 million statistical series from 1960 up until today.

$\begin{array}{lll}\begin{array}{l}\text { Printed publications } \\ \text { FAO yearbook }\end{array} & \begin{array}{l}\text { Publication } \\ 1 \text { issue/year }\end{array} & \begin{array}{l}\text { Web/Format } \\ \text { Yes, selection. } \\ \text { HTML }\end{array} \\ \begin{array}{l}\text { Databases / } \\ \text { Link collections } \\ \text { FAOSTAT }\end{array} & \text { Web/Format } & \text { Accessibility } \\ & \text { Yes. Database } & \text { Free }\end{array}$

Source: FAO, http://www.fao.org/, March 2004.

International Labour Office (ILO) is a labour organization that plans strategies and programmes to promote fundamental human rights, to improve working and living standards and to increase employment opportunities. ILO issues a long list of publications containing statistics concerning work related questions, amongst which is the Yearbook of labour statistics. The organization also has a content-filled website with numerous statistics. Available here is LABORSTA, a database focused on labour statistics, covering variables such as the population's economic activities (from 1945-), employment, unemployment, salaries and similar.

For statistics on child labour one can follow the link Child labour: statistical information and monitoring program on child labour (SIMPOC).

\begin{tabular}{lll}
$\begin{array}{l}\text { Printed publications } \\
\text { Yearbook of labour } \\
\text { statistics }\end{array}$ & $\begin{array}{l}\text { Publication } \\
1 \text { issue/year }\end{array}$ & $\begin{array}{l}\text { Web/Format } \\
\text { No }\end{array}$ \\
$\begin{array}{l}\text { Databases / } \\
\text { Link collections }\end{array}$ & Web/Format & Accessibility \\
LABORSTA & Yes. Database & Free \\
Child labour (IPEC) & Yes. PDF & Free \\
\hline
\end{tabular}

Source: ILO, http://www.ilo.org/, March 2004.

World Health Organization (WHO) steers and coordinates international health work. WHO also works to coordinate and further research on the prevention of different diseases. The world health report, which deals with the current situation with regard to world health, and which has an annex with statistical data, has been published by WHO since 1995. Reports from recent years are available for downloading on WHO's website. During 1965- 
1998 WHO issued the World health statistics annual, which contains statistics on the health and medical care sector. Since 1997 this information has been presented in WHO's database, WHOSIS (WHO statistical information system), on the organization's website. Also available, under the heading, Research tools, is A guide to statistical information at WHO (WHOSIS), which offers guidance to epidemic and statistical information furnished by WHO.

\begin{tabular}{lll}
$\begin{array}{l}\text { Printed publications } \\
\text { The world health } \\
\text { report }\end{array}$ & $\begin{array}{l}\text { Publication } \\
\text { World health statistics } \\
\text { annual }\end{array}$ & $\begin{array}{l}\text { Web/Format } \\
\text { Yes. PDF }\end{array}$ \\
$\begin{array}{l}\text { Databases / } \\
\text { Link collections }\end{array}$ & No \\
$\begin{array}{l}\text { WHOSIS } \\
\text { A guide to statistical } \\
\text { information at WHO } \\
\text { (WHOSIS) }\end{array}$ & Web/Format & Accessibility \\
\hline
\end{tabular}

Source: WHO, http://www.who.int/, March 2004.

United Nations Population Fund (UNFPA), helps to establish health programmes concerned with family planning and sexual and reproductive health, and also deals with questions pertaining to fast population growth. UNFPA's publications, Annual report and State of world population, contain statistical information that can be retrieved via UNFPA's website. In another database called, Population and reproductive health: Country profiles, country-by-country facts and figures can be gathered with the possibility of comparing up to five countries simultaneously.

\begin{tabular}{lll}
$\begin{array}{l}\text { Printed publications } \\
\text { Annual report }\end{array}$ & $\begin{array}{l}\text { Publication } \\
1 \text { issue/year }\end{array}$ & $\begin{array}{l}\text { Web/Format } \\
\text { Yes. PDF / } \\
\text { HTML }\end{array}$ \\
$\begin{array}{l}\text { State of world } \\
\text { population }\end{array}$ & 1 issue/year & Yes. PDF / \\
HTML \\
$\begin{array}{l}\text { Databases / Link } \\
\text { collections }\end{array}$ & Web/Format \\
$\begin{array}{l}\text { Population and } \\
\text { reproductive health: } \\
\text { Country profiles }\end{array}$ & Yes. Database & Accessibility \\
\hline
\end{tabular}

Source: UNFPD, www.unfpa.org/, March 2004.

United Nations Development Programme (UNDP), which carries out much of its work in Africa, assists countries in building up the capacity for 
sustained development. It is a global network for human development, which works towards the improvement of living conditions, and which is active in many different areas. UNDP focuses much of its work on the promotion of democracy, supportive initiatives for peace, reconciliation and the prevention of crises, and the fight against the HIV/AIDS epidemic. It also supports environmental programmes, as well as working towards building up communications technology in Africa. The UNDP has been publishing the Human development report, a publication which also contains statistical data, in cooperation with independent researchers, since 1990. Reports from 1994 onwards are available either in full or in part, and are accessible via the website. The organization works in close cooperation with governments all over the world and has access to the national statistics of individual countries. The UNDP has compiled different development indexes, among which is the Human development indicators (HDI) index, which measures human development in terms other than solely according to income.

\begin{tabular}{lll}
$\begin{array}{l}\text { Printed publications } \\
\text { Human development } \\
\text { report }\end{array}$ & $\begin{array}{l}\text { Publication } \\
1 \text { issue/year }\end{array}$ & $\begin{array}{l}\text { Web/Format } \\
\text { Yes. PDF }\end{array}$ \\
$\begin{array}{l}\text { Databases / } \\
\text { Link collections }\end{array}$ & Web/Format & Accessibility \\
$\begin{array}{l}\text { Human development } \\
\text { indicators }(H D I)\end{array}$ & Yes. & Free \\
\hline
\end{tabular}

Source: UNDP, http://www.undp.org/, March 2004.

United Nations High Commissioner for Refugees (UNHCR) works for the rights of refugees to protection while attempting to find lasting solutions to their problems. UNHC's yearbook, Statistical yearbook, incorporates an annex with statistical tables. Current statistics focusing on development and change concerning people who are fleeing are also presented in: UNHCR's statistical reports, Global refugee trends, 2002 statistics on asylum seekers: Refugees and others of concern to UNHCR and Asylum trends and statistics at a glance. All these reports and documents contain comprehensive statistics. All publications are available for downloading on the website under the heading, Statistics. 


\begin{tabular}{|c|c|c|}
\hline Printed publications & Publication & Web/Format \\
\hline Statistical yearbook & 1 issue/year & Yes. PDF \\
\hline $\begin{array}{l}\text { UNHCR's statistical } \\
\text { reports }\end{array}$ & $\begin{array}{l}\text { Several } \\
\text { issues/year }\end{array}$ & Yes. PDF \\
\hline Global refugee trends & $\begin{array}{l}\text { Several } \\
\text { issues/year }\end{array}$ & Yes. PDF \\
\hline $\begin{array}{l}\text { The state of the world's } \\
\text { refugees }\end{array}$ & 2000 & Yes. PDF \\
\hline $\begin{array}{l}2002 \text { statistics on } \\
\text { asylum seekers: } \\
\text { refugees and others of } \\
\text { concern to UNHCR }\end{array}$ & 2003 & Yes. PDF \\
\hline Asylum trends & $\begin{array}{l}\text { Several } \\
\text { issus/year }\end{array}$ & Yes.PDF \\
\hline Statistics at a glance & $\begin{array}{l}\text { Several } \\
\text { issues/year }\end{array}$ & Yes.PDF \\
\hline
\end{tabular}

World Food Programme (WFP) has the task of distributing food during famines, and helps to rebuild societies through the "Food-for-work" project. Every year WFP in statistics is published, which contains information about the organization's activities. The reports can be accessed via the website. Here country-by-country facts and figures can be found, partly on WFP's activities and partly on world starvation (World hunger).

\begin{tabular}{lll}
$\begin{array}{l}\text { Printed publications } \\
\text { WFP in statistics }\end{array}$ & $\begin{array}{l}\text { Publication } \\
1 \text { issue/year }\end{array}$ & $\begin{array}{l}\text { Web/Format } \\
\text { Yes. PDF }\end{array}$ \\
$\begin{array}{l}\text { Databases / } \\
\text { Link collections }\end{array}$ & Web/Format & Accessibility \\
World hunger & Yes. Database & Free \\
\hline Source & WFP, &
\end{tabular}

Source: WFP, http://www.wpf.org/, March 2004.

United Nations Educational, Scientific, and Cultural Organization (UNESCO), works towards facilitating the understanding of major changes in the world and draws up of intellectual and ethical and guidelines. During the years 1964-1999, UNESCO published the Statistical yearbook. In 1999 UIS (The UNESCO Institute for Statistics) was established, which publishes extensive statistics on its website on education, reading and writing skills, communication and culture (book publication, film, music, libraries and media), as well as science and technology (national data about personal resources and information within research and experimental development, $\mathrm{R} \& \mathrm{D})$. 


\begin{tabular}{lll}
$\begin{array}{l}\text { Printed publications } \\
\text { Statistical yearbook }\end{array}$ & $\begin{array}{l}\text { Publication } \\
1964-1999\end{array}$ & $\begin{array}{l}\text { Web/Format } \\
\text { No }\end{array}$ \\
$\begin{array}{l}\text { Databases / } \\
\text { Link collections }\end{array}$ & Web/Format & Accessibility \\
$\begin{array}{l}\text { UIS-The UNESCO } \\
\text { institute for statistics }\end{array}$ & $\begin{array}{l}\text { Yes. Various } \\
\text { formats }\end{array}$ & Free \\
\hline
\end{tabular}

Source: UNESCO, http://www.unesco.org/, March 2004

United Nations Children's Fund (UNICEF), protects, promotes, and defends children's rights. UNICEF publishes a great number of publications every year, among which is a report on children's well-being, The state of the world's children. The organization has a full website, on which, in order to find statistics, one searches via the headings Information by country or What we do. Statistics are presented at the end of each country or subject. Further links lead to the website Childinfo.org, on which UNICEF's principle website is to be found. This contains detailed country specific information that is reported in Progress since the World Summit for Children: A statistical review (2001). Both reports and other publications are available for downloading from the organization's website.

\begin{tabular}{|c|c|c|}
\hline Printed publications & Publication & Web/Format \\
\hline $\begin{array}{l}\text { The state of the world's } \\
\text { children }\end{array}$ & 1 issue/year & Yes. PDF \\
\hline $\begin{array}{l}\text { Progress since the } \\
\text { world's summit for } \\
\text { children: } \\
\text { A statistical review }\end{array}$ & $\underline{2001}$ & Yes. PDF \\
\hline $\begin{array}{l}\text { Databases / } \\
\text { Link collections }\end{array}$ & Web/Format & Accessibility \\
\hline Childinfo.org & Yes. Database & Free \\
\hline
\end{tabular}

Source: UNICEF, http://www.unicef.org/, March 2004.

Joint United Nations Programme on HIV/AIDS (UNAIDS), works to prevent the spread of HIV, to provide care for those infected or affected by the disease and to reduce the individual's and society's vulnerability to HIV/AIDS. UNAIDS is comprised of UNDP, UNICEF, UNFPA, UNDCP, ILO, UNESCO, WHO and the World Bank. Several reports are accessible on the website such as, The report on the global HIV/AIDS epidemic 2002, which contains statistical tables. AIDS epidemic update should, in particular, be mentioned, which are country-by-country fact sheets with statistical information on HIV/AIDS, compiled in cooperation with WHO. 
Printed publications

AIDS epidemic update

The report on the

global HIV/AIDS

epidemic
Publication

1 issue/year

2002
Web/Format

Yes. PDF

Yes. PDF

Source: UNAIDS, http://www.unaids.org/, March 2004.

World Bank publishes, inter alia, Africa development indicators, a detailed collection of developmental data from large parts of Africa, and World development report (WDR), which is a guide to the economic, social and environmental state of the world, and which contains statistical information. Global development finance (GDF) is the World Bank's annual study of trends and future outlook for the financial flow in developing nations. This also includes statistics of national debts along with summarized data of regions and income groups. There is a great deal of information to be found about Africa on the World Bank's website, which is well worth investigating. Many accessible databases exist, some of which are free. Data query gives access to a selection from the larger database World development indicators (WDI online), which is a comprehensive data collection focusing on development and including information on population, environment, economy, countries and markets. GDF online is another big database containing statistics on countries' debts. Africa household survey is a collection of over 100 surveys and censuses from African countries.

\begin{tabular}{|c|c|c|}
\hline Printed publications & Publication & Web/Format \\
\hline $\begin{array}{l}\text { Africa development } \\
\text { indicators }\end{array}$ & 1 issue/year & $\begin{array}{l}\text { Yes, partly } \\
\text { PDF/HTML }\end{array}$ \\
\hline $\begin{array}{l}\text { World development } \\
\text { report }\end{array}$ & 1 issue/year & Yes. PDF \\
\hline $\begin{array}{l}\text { Global development } \\
\text { finance }\end{array}$ & 1 issue/year & $\begin{array}{l}\text { Yes, partly } \\
\text { PDF }\end{array}$ \\
\hline $\begin{array}{l}\text { Databases / } \\
\text { Link collections }\end{array}$ & Web/Format & Accessibility \\
\hline Data query & Yes. Database & Free \\
\hline WDI online & Yes. Database & License \\
\hline GDF online & Yes. Database & License \\
\hline $\begin{array}{l}\text { Africa household } \\
\text { survey databank }\end{array}$ & Yes. Database & $\begin{array}{l}\text { Free. } \\
\text { Registration }\end{array}$ \\
\hline
\end{tabular}

Source: The World Bank, http://www.worldbank.org/, March 2004. 
International Monetary Fund (IMF) publishes statistics on economic conditions, primarily within the membership countries, and issues several publications. International financial statistics has been released monthly since 1948. In addition to this there is a yearbook containing statistical information concerning financial questions on a national and international level, exchange rates, banking, money, interest rates, prices, production, and more. This is available via the website, but only at a cost. Government finance statistics yearbook provides detailed information on economic and financial statistics. In addition, there are the publications IMF country reports and World economic outlook, which are available for downloading from the website. Also available there is the World economic outlook (WEO) database including more statistics than are provided in the printed reports. The statistics appearing in International financial statistics and World economic outlook may differ from each other on account of various factors such as time, focus, method and selection technique.

\begin{tabular}{|c|c|c|}
\hline Printed publications & Publication & We/Format \\
\hline $\begin{array}{l}\text { International financial } \\
\text { statistics }\end{array}$ & 1 issue/month & Yes. License \\
\hline $\begin{array}{l}\text { Yearbook with the } \\
\text { same title }\end{array}$ & 1 issue/year & No \\
\hline $\begin{array}{l}\text { Government finance } \\
\text { statistics yearbook }\end{array}$ & 1 issue/year & No \\
\hline IMF country reports & $\begin{array}{l}\text { Several } \\
\text { issues/year }\end{array}$ & Yes. PDF \\
\hline $\begin{array}{l}\text { World economic } \\
\text { outlook }\end{array}$ & $\begin{array}{l}\text { Several } \\
\text { issues/year }\end{array}$ & Yes. PDF \\
\hline $\begin{array}{l}\text { Databases / } \\
\text { Link collections }\end{array}$ & Web/Format & Accessibility \\
\hline $\begin{array}{l}\text { International financial } \\
\text { statistics }\end{array}$ & Yes. Database. & License \\
\hline $\begin{array}{l}\text { World economic } \\
\text { outlook (WEO) } \\
\text { database }\end{array}$ & Yes. Database & Free \\
\hline
\end{tabular}

Source: IMF, http://www.imf.org/, March 2004. 


\section{References}

Blake, David (2002) "From paper to pdf? The publications of Africarelatedinternational organizations, past, present and future" African research \& documentation, no 89, pp 57-67.

Bondesson, Lennart (2003) "Statistik" [Electronic] Nationalencyclopedin, 7 screen pages. http://www.ne.se/jsp/search/article.jsp?i art id=314394 [read: 2003-0304].

Fyhrlund, Alf and Gretel Eklöf (2002) "Att hitta global statistik på Internet". Stockholm: Statistiska Centralbyråns bibliotek. (Seminar 7 November, unprinted.)

Kpedekpo, G. M. K. (1981) Social and economic statistics for Africa. Their sources,collection, uses and reliability. London: George Allen \& Unwin.

Ribe, Martin (1996) "Statistik med kvalitet" VärldsBulletinen, no 4, pp12-13.

Statistiska centralbyråns hemsida [Home page] (2003) "Vad är statistik?" [Electronic] in Statistikskolan. 1 screen page. PDF file. http://www.scb.se/Grupp/Klassrummet/_Dokument/Vad_ar_statistik.pdf [read: 2003-03-04].

Uppsala University’s home page (2002) Att söka information. Informationskällor och olika typer av publikationer [Electronic] 12 screen pages.

http://www.ub.uu.se/kurs/tutorial/start.cfm [read 2003-03-04].

\section{Web resources}

Nordic Africa Institute - www.nai.uu.se/

NOAK (Nordic Africa Institute's online catalogue - http://noak.nai.uu.se/F/

SCB - www.scb.se/

WebStat - http://www.linkkitalo.fi/SPT--BrowseResources.php?ParentId=28

ADB - www.afdb.org/

AFRISTAT - www.afristat.org/

BIS - www.bis.org/index.html

FAO - www.fao.org

ILO - www.ilo.org/

IMF - www.imf.org/

OECD - www.oecd.org/unsd/

$\mathrm{UN}$ - http://unstats.un.org/unsd/

UNAIDS - www.unaids.org

UNCTAD - www.unctad.org 
UNDP - www.undp.org/

UNECA - www.uneca.org/

UNESCO - www.unesco.org/

UNFPA - www.unfpa.org/

UNHCR - www.unhcr.org/

UNICEF - www.unicef.org/

World Bank - www.worldbank.org/

WHO - www.who.int/en/

WPF - www.wpf.org/ 


\section{Search terms in NOAK}

Index terms used in NOAK - the Nordic Africa Institute's online catalogue, consist of subject headings taken from Macrothesaurus for information processing in the field of economic and social development (Paris/New York: OECD/UN, 1998, 5. ed.).

In order to search for statistics, the following words, inter alia, are useful: Statistical analysis; Statistical data; Statistical services; Statistical tables; Agricultural statistics; Demographic statistics; Economic statistics; Educational statistics; Employment statistics; Energy statistics;

Environmental statistics; Financial statistics; Fishery statistics; Food statistics; Forestry statistics; Health statistics; Housing statistics; Industrial statistics; Labour statistics; Medical statistics; Migration statistics;

Production statistics; Social statistics; Trade statistics; Transport statistics; Vital statistics; Household surveys; Housing censuses; Population censuses; Indicators; Demographic indicators; Development indicators; Economic indicators; Educational indicators; Health indicators; Social indicators; Official documents, and more. 


\section{Maps}

\section{Peter Kinlund}

The available cartographic material for the whole or parts of the African continent is naturally very disparate both in terms of content and quality. This material ranges from tourist maps that lack exactness to extremely detailed topographic maps at a scale of

1:5 000. They can be simple small-scale country maps that can be accessed on the Internet, or specialised maps that represent complex features such as the distribution of bilharzia in a particular area of the continent (Gear 1980). They may also be sketches over local land use drawn by villagers, or $19^{\text {th }}$ century documents produced in the service of European colonisation. Even seemingly similar large-scale topographical maps can vary considerably in terms of quality.

Africa's colonial past continues to mirror itself to a significant extent in the mapping of the continent. It was above all the British and French colonial administrations that conducted fairly comprehensive mapping surveys of their respective colonies. Following independence most African nations have continued to draw on the cartographic expertise of their former colonial rulers, partly as a component of bilateral development assistant. The British Department of Overseas Surveys (DOS) and the French Institut Géographique National (IGN) have accordingly played a very important role in the mapping of the continent. The colonial administrations in former Spanish, Portuguese, Italian and German territories have, in most cases, been less active in this regard. Mapping expertise from countries such as Sweden, Poland, China, USA, and perhaps above all the former Soviet Union, have contributed to the mapping of various regions of the continent.

Maps are of course rarely if ever value-free, and they can reflect the interests and ambitions of the specific authorities that commission their production. Colonial administrations used maps as an instrument in their imperial enterprises (see Atkinson 1994). Moroccan maps of today, and also those produced by international map publishers, show Western Sahara as a part of Morocco despite the fact that this annexation has never been recognized by the UN or OAU. Maps were also used as a political instrument by the South African government during the apartheid era. Areas of the country with large black populations, for example, often lack any place names whereas small villages with predominantly white populations were clearly marked. Soweto, one of Africa's largest urban areas, was not even marked on most maps during the apartheid era. 


\section{Tourist maps}

Many international map publishing houses produce maps over the whole or parts of Africa as well as maps over individual countries. Particularly useful and well-reputed are Michelins maps produced at a scale of 1: 4000000 which cover the whole continent in three sheets. Concerning maps of individual countries, areas that are of most interest for tourists such as Egypt, Kenya and South Africa are far better represented than areas that rarely feature on tourists travel itineries such as Chad or Angola. The Canadian based International Travel Maps and the French based Institut Géographique National (IGN) offer the best inventory of maps in the latter category. The Hungarian company Cartographia also has a fairly good catalogue of maps in this category. Together, these companies offer a range of maps over all African countries at scales varying in detail from

1: 100000 (Mauritius) to 1: 3000000 (Congo-Kinshasa). In addition to these, South African publishers have a fairly comprehensive catalogue of road and tourist maps for southern Africa. Various publishers also offer a wide range of town and city maps, maps of popular coastal areas and of national parks. Map Studio from South Africa has published an Illustrated road atlas of Africa (2000) which, in addition to road maps for the entire continent, also includes maps over many national parks and larger urban areas.

\section{GeoKatalog}

Perhaps the best way to gain a comprehensive overview of the supply of commercial maps that primarily serve the tourist sector of the market is to use the annually updated GeoKatalog 1 Touristik issued by GeoCenter in Stuttgart, Germany.

GeoCenter also distributes the most comprehensive catalogue of maps of a more scientific character, GeoKatalog 2. The catalogue is published in three volumes in a loose-leaf system comprising approximately 1700 pages and parts of this catalogue are revised on a bi-annual basis. Almost all of the maps in the catalogue can be ordered from the company. Other useful reference books which provide overviews of the various types of existing maps - or formerly existing maps - over Africa are World mapping today (Parry \& Perkins 2000) produced by the University of Reading, and Inventory of world topographic mapping (Böhme 1989-93) published by the International Cartographic Association. 


\section{Survey maps}

A number of international map series cover Africa at a reasonably detailed scale. One of these is Karta mira at a scale of 1: 2500 000. The series is the result of collaboration between mapping authorities from the Soviet Union, DDR, Poland, Czechoslovakia, Hungary, Romania and Bulgaria between 1964-1988 and comprises a total of 234 sheets. Approximately 20 of these sheets cover the African continent. A further publication at a similar scale is the American Africa series 2201 published by the Defence Mapping Agency in Washington between 1968-1982. This work comprises 36 maps at a scale of 1: 2000000 .

\section{International map of the world}

Africa is of course represented in the globally encompassing International map of the world (IMW) produced at the scale of 1: 1000 000, also known as The millionth map. This map series was initiated already in 1912 and comprises 2122 map-sheets. A number of these maps have been produced by national mapping departments, others by British, American or Soviet/Russian organisations, while others have been produced by the United Nations. The maps accordingly vary considerably both in terms of age and quality.

\section{MIR (World Series)}

A more detailed map series is Mir, often called World series, produced at a scale of 1: 500000 and published by Soviet and Russian departments from 1971 onwards. Approximately 2500 map-sheets have been published and around 500 of these cover the African continent. This map series is now also available in digital form (see below).

Further types of maps that cover Africa - and the remaining world - are Operational navigation chart at a scale of 1: 1000000 and Tactical pilotage chart at a scale of 1: 500 000. Both of these series are produced for in-flight navigation, but can naturally be used for other purposes.

\section{Afrika-Kartenwerk}

A very detailed map series over a number of selected regions of Africa is the German production Afrika-Kartenwerk. This map series comprises more than 60 maps at a scale of 1: 1000000 (and a similar number of written explanatory commentaries) and presents and discusses a range of themes for four quadrants of Africa: Nord (parts of Algeria and Tunisia), West (parts of Nigeria and Cameroon), Ost (parts of Kenya, Uganda and Tanzania) and Süd (parts of South Africa, Mozambique and Swaziland). The disciplinary areas dealt with in the map-series are: topography, geomorphology, geology, pedology, climatology, hydrology, vegetation, population, the built environment, ethnography, agriculture, economic geography, transport geography, medical geography, historical geography and settlement history. 


\section{UNESCO}

UNESCO has produced a number of map series all of which focus on Africa's natural geography. The International geological map of Africa presents the geology of Africa in six map-sheets. These have been produced at a scale of 1: 5000000 and were published between 1985-1990. UNESCO has also initiated the mapping of Africa's vegetation and this has resulted in the publication of the Vegetation map of Africa, also at a scale of

1: 5000000 (three map-sheets). This UN agency has, in collaboration with Association des Servicés Géologiques Africaines, also published the International tectonic map of Africa produced at a scale of 1: 5000000 (nine map-sheets) as well as the Mineral map of Africa and Metamorphic map of Africa, both of these at a scale of 1: 10000 000. Furthermore, UNESCO has together with the FAO produced the Soil map of the world (1970-1981) at a scale of 1: 5000 000. Part VI of this series (3 map-sheets) covers the African continent.

\section{Atlases}

In many cases the simplest method of finding cartographic material concerning aspects of Africa's geography, history or political development is to refer to one or several of the many atlases that have been published. Some atlases are of a more general character, for example The atlas of Africa (Chi-Bonnardel 1980) or Atlas de l'Afrique (2000). Others are more specialised and have a more pronounced focus on aspects such as: African history, culture, contemporary politics, agriculture or climate. Several examples from this category that deserve mention are: The Penguin atlas of African history (McEvedy 1995), Cultural atlas of Africa (Murray 1998) and The atlas of African affairs (Griffiths 1994). (For other examples see the bibliography at the end of this chapter.) Valuable maps over the continent are of course also to be found in atlases that do not specifically deal with the continent. One eminent example here is the recently published World atlas of epidemic diseases (Cliff 2003).

\section{National atlases}

National atlases can prove particularly valuable for accessing information relating to specific countries. Such atlases, often published in book form but also sometimes in the lose-leaf system, contain both general and thematic maps to varying extents. Many editions are, however, now of considerable age and the quality varies a great deal. It should also be pointed out that many of these are also now difficult to locate.

Some of the African national atlases are produced and distributed by their respective national mapping organisations, as for example is the case for Ethiopia, Kenya and Gabon, but the majority are published by French or 
British publishers. A series that was initiated in 1975 and which comprises twelve volumes is published by Jeune Afrique/Editions Jaguar from France. The latest volume was published in 2002 and concentrates on Morocco and Nigeria respectively. A somewhat less ambitious English series which was published in 1971-82 focuses on Liberia, Malawi, Nigeria, Sierra Leone, Tanzania and Zambia (Gnielinski; Agnew; Barbour; Clarke; Berry; Davies).

\section{School atlases}

A more rudimentary but nonetheless useful form of cartographic material can be found in the school atlases that have been published in most countries. These usually include maps over aspects including land use, population distribution, languages, and mineral deposits. It is often the case that these maps have also been produced by European map publishers. Swedish publishers have participated in the production of school atlases for a number of countries or regions, for example, Botswana (1988) and Zanzibar (1983). The largest of the European publishers in this area is Macmillan, which has published school atlases for 17 African countries.

\section{Mapping of individual countries}

The extent to which individual countries have been mapped varies considerably. In addition to the map material that has been discussed above, various national map series produced at varying scales are often also available. Local topographical map series are often available at an intermediate scale, for example, 1: 200000 and in series where the largest scale is 1: 50000 or 1: 100 000. For certain countries, maps over the entire territory are available only at the lowest scale. Territory-wide map series for African countries are also produced by Soviet/Russian and American military and defence departments. These map series are nowadays widely available to the general public (see for example East View Cartographic, Omni Resources map catalogue, and GeoCenter, all of which are listed under the sub-heading "Web resources" at the end of this chapter). In addition to topographic maps, other thematic maps depicting geology, vegetation, population, agro-climate, and a wide range of other themes are also available.

This link shows an example of the Soviet Russian Generalnyi Shtab at a scale of 1: 200000 over Omo River Region in Ethiopia. The map is accessible on the Internet from Earth Sciences \& Map Library at the University of California, Berkeley:

http://www.lib.berkeley.edu/EART/ethiopia/g8030s200s6.html

In order to provide a sense of the range of existing maps for individual countries two countries can be taken as examples; Kenya and Congo 
(Brazzaville). Topographic maps with a complete coverage of Kenya are available at a range of scales: 1: 250000 (47 map-sheets), 1: 100000 (128 map-sheets), and 1: 50000 (340 map-sheets). These map-sheets have been produced since 1948 and have been re-produced or revised at irregular intervals. The majority have been produced by the Department of Overseas Surveys (DOS) from Great Britain in collaboration with the local surveying departments. More recent editions are however, very difficult to access due to the limitations of the Kenyan authorities. Kenya is also covered by Soviet military topographical maps produced at scales of 1: 200000 (17 mapsheets) and 1: 100000 (47 map-sheets). The country is also covered by topographic maps produced by American military departments. These are at a scale of 1: 250000 (15 map-sheets). Geological maps have been produced at scales of 1: 250000 and 1: 125000 (there are also several map-sheets at a scale of 1: 50 000). Additionally, there are thematic maps showing: vegetation, population, hydrogeography, mineral deposits, soils, as well as maps showing soil erosion, climate, languages and dialects, and population density.

Turning to the case of Congo (Brazzaville), it can be said that the availability of detailed maps is considerably more limited. There is territorywide coverage of topographic maps (44 map-sheets) produced between 1948-1978 by the Institut Géographique National at a scale of 1: 200000. The same institute also produced 45 map-sheets at a scale of 1: 50000 but these cover only small areas of the country. In addition, there are also Soviet and American military maps at the scales of 1: 200000 (26 map-sheets) and 1: 250000 (17 map-sheets) respectively. There are also geological maps, soil maps, and a metallogenic map at the scales of 1: 200000 and 1: 1000000 .

A recommended reference for an up to date account of the maps that are available for different countries is Geo Katalog 2 (see above).

\section{Historical maps}

For readers who are interested in historical maps over Africa there exists a large body of published work. Some examples are: Collector's guide to maps of the African continent and southern Africa (Tooley 1969), Africa on maps dating from the twelfth to the eighteenth century (Klemp 1968), and Norwich's maps of Africa: An illustrated and annotated carto-bibliography (Norwich 1997). A number of handbooks can also be recommended for those interested in locating sought-after maps, two good examples are: Keyguide to information sources in cartography (Hodgkiss \& Tatham 1986), and Information sources in cartography (Perkins \& Parry 1990). 


\section{Digital map material}

Maps are of course nowadays also available in digital form. A vast array of basic maps and even detailed topographic or thematic maps can easily be found on the Internet. Some useful Internet addresses go to: PerryCastaneda Library Map Collection at the University of Texas in Austin, to Earth Sciences \& Map Library at the University of California, Berkeley, and to Oddens' bookmarks. The fascinating world of maps and mapping and to Kartensammlung der ETH-Bibliothek, Zurich.

For those seeking outline maps over Africa or African states, perhaps for use as teaching aids, these can be found on the Internet. See for example National Geographic: Xpedition atlas or What you need to know about geography.

A good example of digital cartographic material distributed as CD-Rom is Africa data sampler: A geo-referenced database for all African countries (World Resources Institute 1995). This material includes digital maps of all African countries at a scale of 1:1000 000 and the programme incorporates the ability to combine different layers of information such as borders, settlements, roads, land use, protected areas etc. This map material does require that users have the appropriate software for this purpose, in this case ArcView. A simpler version - Africa interactive maps - is available for school use.

The above mentioned Russian map series produced at a scale of 1: 500000 is now also available in digital form, and all of the Africa mapsheets are included on three CD-Rom. This series is distributed by Omni Resources.

\section{References}

Africa today. An atlas of reproducible pages (1994). Wellesley: World Eagle

Agnew, S (1973) Malawi in maps. New York/London: Holmes \& Meier/Arnold

Overseas,

Ajayi, J.F Ade (1992) Historical atlas of Africa. London: Longman

Atkinson, D. (1994) "Arrows, empires and ambitions in Africa. The geopolitical cartography of fascist Italy” in Stone, J. C. ed. Maps and Africa. Proceedings of a Colloquium at the University of Aberdeen, April 1993, Aberdeen: Aberdeen University African Studies Group

Atlas de l'Afrique (2000). Paris: Editions du Jaguar/Jeune Afrique (2. éd.)

Atlas du Burundi (1979-81). Gradignan: Association pour l’Atlas du Burundi

Atlas du Rwanda (1981). Kigali: National University 
Atlas historique de L'Afrique (1993). Paris: Editions du Jaguar/Jeune Afrique

Les Atlas Jeune Afrique (République Islamique de Mauretanie, 1977; République Populaire du Congo, 1977; République du Zaire, 1978; Cameroun, 1979; Mali, 1980; Niger, 1980; Senegal, 1980; Togo, 1981; République Centrafricaine, 1984; Tunisie,1985; Côte d’Ivoire, 1988; Burkina Faso, 2001; Guinée Equatoriale, 2001; Congo, 2001; Maroc, 2002; Nigeria, 2002). Paris: Editions du Jaguar/Jeune Afrique

Atlas Jeune Afrique du continent africain (1993) Paris: Editions du Jaguar/Jeune Afrique

Atlas national du Sénégal (1977). Dakar: Institut Fondamental d’Afrique Noire

Atlas of Swaziland (1983). Lobamba: Swaziland National Trust Commission

Atlas of Tanzania (1967). Dar es Salaam: Survey and Mapping Division

Atlas pratique du Tchad (1972). Paris: Institut Géographique National

Barbour, K.M et al. eds. (1998) Nigeria in maps. New York: Holmes \& Meier (First published London: Hodder \& Stoughton, 1982)

Berry, L (1971) Tanzania in maps. London: Hodder\& Stoughton

The Botswana Society social studies atlas (1988). Gaborone: Botswana Society in collaboration with the Governement of Botswana and Esselte Map Service

Böhme, Rolf (1989-1993) Inventory of world topographic mapping. London: International Cartographic association/Elsevier

Chi-Bonnardel, Régine van (1973) The atlas of Africa. Paris: Jeune Afrique

Christopher, A.J. (1994) The Atlas of apartheid. London: Routledge

Christopher, A.J. (2000) The atlas of changing South Africa. London: Routledge

Clarke, J (1972) Sierra Leone in maps. New York/London: Holmes \& Meier/Arnold Overseas

Cliff, A., P. Haggett \& M. Smallman-Raynor (2003) World atlas of epidemic diseases. London: Hodder Arnold

Davies, D. Hywel (1971) Zambia in maps. New York/London: Holmes \& Meier/Arnold Overseas

Davies, H.R.J. (1973) Tropical Africa. An atlas for rural development. Cardiff: University of Wales Press

Fage, J.D. (1978) An atlas of African history. London: Arnold (2. ed.)

FAO (1986) African agriculture the next 25 years. Atlas of African agriculture. Rome: FAO

FAO (2001) Atlas of water resources and irrigation in Africa. Rome: FAO. (Land and water digital media series, 13)

Freeman-Grenville, G.S.P. (1976) A modern atlas of African history. London: Collings

Gear, J.H.S., R.J. Pitchford \& J.A. van Eeden, eds. (1980) Atlas of bilharzia in southern Africa. Johannesburg: S.A. Institute for Medical Research 
Geo Katalog 1. Touristik. (1972-). Stuttgart: GeoCenter

Geo Katalog 2 (1976-). Stuttgart: GeoCenter. (English ed. 1993-)

Gnielinski, S. von (1972) Liberia in maps. New York/London: Holmes \& Meier/Arnold Overseas

Griffiths, Ieuan Ll (1994) The atlas of African affairs. London: Routledge. (2. ed.)

Hodgkiss, A.G. \& A.F. Tatham (1986) Keyguide to information sources in cartography. London: Mansell

Illustrated road atlas of Africa (2000). Rivonia: Map Studio

Institute Pédagogique National, Gabon (1983) Geographie et cartographie du Gabon. Atlas illustré. Paris: EDICEF

Jackson, S.P. ed. (1961) Climatological atlas of Africa. Lagos: CCTA/CSA

Joly, J. (2002) L'Afrique, atlas historique. L'Afrique et son environnement européen et asiatique. Paris: Paris-Méditerranée

Kasule, Samuel (1998): The history atlas of Africa. London: Macmillan

Klemp, Egon (1968) Africa on maps dating from the twelfth to the eighteenth century. Leipzig: Edition Leipzig

Kwamenha-Poh, M. et al. (1982) African history in maps. London: Longman

Leroux, M. (1983) The climate of tropical Africa. Paris: Champion

McEvedy, Colin (1995) The Penguin atlas of African history. London/New York: Penguin

McIlwaine, John (1997) Maps and mapping of Africa. A resource guide. London: Hans Zell

Murray, Jocelyn ed. (1998) Cultural atlas of Africa. New York: Checkmark Books

(Rev. ed)

National atlas of Ethiopia, (1988). Addis Abeba: Ethiopian Mapping Authority

National atlas of Kenya (1970). Nairobi: Survey of Kenya (3. ed.)

National atlas of Malawi (1985). Blantyre: Department of Surveys

National atlas of South West Africa (Namibia)/Nasionale atlas van Suidwes-Afrika (Namibië) (1983). Windhoek: Directorate Development Co-ordination

National atlas of Zambia (1985). Lusaka: Survey Department

Norwich, O.I. (1997) Norwich's maps of Africa. An illustrated and annotated carto-bibliography. Norwich: Terra Nova Press

Parry, R.B. \& C.R. Perkins (2002) World mapping today. Reading: University of Reading

Penfold, P.A ed. (1982) Maps and plans in the Public Record Office, 3: Africa. London: Public Records Office

Perkins, C.R. \& R.B. Parry eds. (1990) Information sources in cartography. London: Bowker-Saur 
Raschke, E.et al. eds. (1991) Solar radiation atlas of Africa. Global and diffuse radiation fluxes at ground level derived from imaging data of the geostationary satellite METEOSAT 2. Rotterdam: Balkema

Reader's Digest atlas of southern Africa (1984). Cape Town: Reader's Digest

Sayer, Jeffrey et al. eds. (1992) The conservation atlas of tropical forests - Africa. London: Macmillan

School atlas for Zanzibar (1983). Zanzibar: Ministry of Education with Esselte Map Service

Tooley, R.V. (1969) Collector's guide to maps of the African continent and Southern Africa. London: Cork Press

World Resource Institute (1995) Africa data sampler. A geo-referenced database for all African countries. Washington DC: World Resource Institute (CD-ROM version)

\section{Web resources}

Afrika-Kartenwerk. Berlin -

http://www.schweizerbart.de/pubs/series/afrikakartenwerk19.htm

Cartographia. Budapest - http://www.cartographia.hu

Earth Sciences \& Map Library.University of California. Berkeley http://www.lib.berkeley.edu/EART/MapCollections.html

East View Cartographic. Minneapolis - http://www.cartographic.com

GeoCenter. Stuttgart - http://www.geokatalog.de

Institut Géographique National (IGN). Paris - http:// www.ign.fr

International travel maps. Vancouver - http://www.itmb.com

Kartensammlung der ETH-Bibliothek. Zürich http://www.maps.ethz.ch/maplibraries.html

Macmillan in Africa. London - http://www.macmillan-africa.com

National Geographic. Xpedition atlas http://www.nationalgeographic.com/xpeditions/atlas/

Oddens' bookmarks.The fascinating world of maps and mapping. Utrecht http://oddens.geog.uu.nl/index.html

Omni Resources map catalogue. Burlington - http://www.omnimap.com/maps.htm

Perry-Castañeda Library Map Collection, University of Texas. Austin http://www.lib.utexas.edu/maps/africa.htm

What you need to know about geography http://geography.about.com/library/blank/blxindex.htm 


\section{Official publications}

\section{António Lourenço}

Official publications comprise all publications produced under the official auspices of legislative bodies, decision-making and judicial organs, civil service departments, courts of law, independent institutions, committees, people in authority, etc. IFLA (International Federation of Library Associations and Institutions) describes official publications as follows:

"An official publication is defined by the status of the issuing source regardless of the subject matter, content or physical form" (Nurcombe 1997, p. xix). "Official documents" is the general search term for material of this nature in the Nordic Africa Institute's online library catalogue.

The library began acquiring official publications as far back as1962 when the Nordic Africa Institute commenced its activities, since they were considered to constitute fundamental and crucial source material within the field of the social sciences. With time, an acquisitions profile came to be established in line with the library's subject focus and based on the material's significance, accessibility and demand. Official publications are essential to social scientific studies on Africa as they are principle information sources for economic, legal, government and political data and are considered to be scientific tools of lasting value.

An important problem to consider regarding official publications from certain African countries is the question of reliability. The reason for this is that such publications may be used as mouthpieces by governmental powers in order to further their political goals or to give expression to political values during times of crisis. This mainly concerns countries with small volumes of official documents that tend to limit access to information. Thus, even collections of official publications from colonial times should be read through critical eyes. Political instability and catastrophes that repeatedly befall the African continent sometimes make it impossible to gain access to certain official publications. A connection can be made between conflict and war on the one hand, and the number of official documents issued on the other. In addition, the economic crisis affecting many African states has left a mark on the way in which public administrations function in those countries. Other problems arise when certain official publications are difficult to obtain as few lists are available for checking newer publications and also because, in the absence of a central government printer, it is sometimes necessary for various sectors of the government administration to publish their own material. Library acquisitions are made via agents, from bookshops, by direct contact with the producers, or through embassies. Today it is possible to procure official publications via email in certain cases, from countries whose central statistical agencies have their own websites. 
Thanks to developments in the field of information technology, a radical change has begun to take place. Nowadays, authorities with the important task of disseminating basic decision-making data are choosing with greater frequency to make their official publications available on the Internet. The range, however, is still extremely uneven, and while states such as South Africa and Tanzania offer a rich collection of official publications in full text, many in PDF format, there are other countries that supply only a limited number of official publications in summarized form. Yet, it can be anticipated that a basic range of official publications from all of Africa's countries will be available before long on the Internet in the form of constitutions, censuses, development plans, budgets, economic reports, diverse statistics, and so on. A problem, however, is that this type of material could be removed from the Net as soon as it loses its current interest value. Therefore, the Nordic Africa Institute, with its aim of preserving such publications for future research, must continue to purchase them in the form of paper publications, CD-ROMs and microfiche. Under discussion at present are questions of copyright policy regarding the preservation of important documents only available on the Internet.

A large selection of the Nordic Africa Institute library's collection of official publications can be located in the library catalogue, NOAK, and in the Swedish libraries database, LIBRIS. A small number of older publications held by the library are uncatalogued and are kept in storage. It is quite simple to search in NOAK. If, for example, one enters "official documents and Mali" in the search field "all fields", a chronological list of official publications from Mali in the library's catalogue will come up; if one enters "population censuses and Kenya", the search result will be a list of documents on population censuses in Kenya that are available in the library. In recent years the growing number of official publications being catalogued in LIBRIS has led to a considerable increase in the demand for such material. In response to this, the library at the Nordic Africa Institute has begun to lend out publications (on 3 weeks reading room loan), chiefly to Nordic research libraries.

Heavy, dull and monotonous official publications are now being replaced by monograph-type formats that make for easier reading. It is enough to take a quick look at publications such as Biological diversity in Namibia - a country study 1998; State of environment for Uganda 1998; Second report on poverty in Kenya, Vol.III: welfare indicators atlas or Côte d'Ivoire: développments économique récents et perspectives: 1998-2000 to see that there are not only numbers and tables in these publications, but also pictures, colour maps and diagrams, printed on high quality paper. In short, these volumes are easy to handle and pleasant to read. 


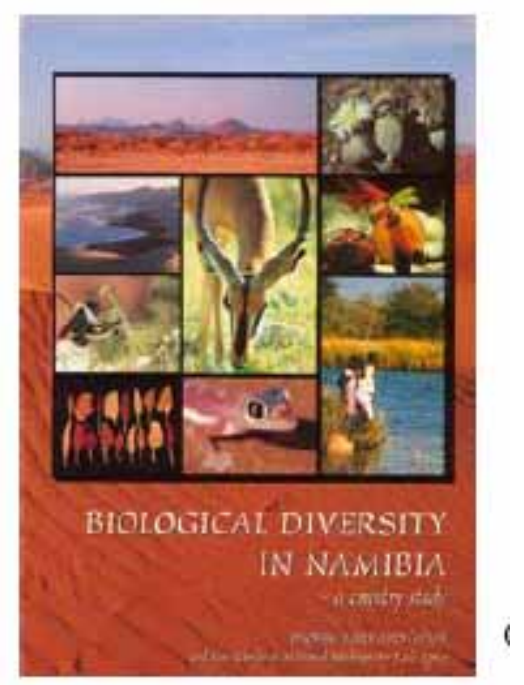

\section{Principle types of official publications}

The library acquires official publications that fall into the following main groups:

1. Parliamentary documents, bills and other related documents: annual and audit reports, official reports of investigations commissions, budget proposals and reports, conference papers, policy documents, etc.

2. Parliamentary debates: the Nordic Africa Institute's library holds a particularly comprehensive collection of debates from South Africa's parliament.

3. Constitutions and legislation.

4. Statistics: annual statistics, statistical abstracts, national accounts, economic and financial indicators, as well as statistical data on agriculture, education, housing, health issues, transport, tourism, the environment, gender, labour, migration, trade and industry. Also available are household surveys and statistics concerning household consumption, social conditions, etc.

5. Population censuses: at regional as well as national level. These are probably the most important statistical data.

6. Development plans, both national and local.

7. Policy documents concerning all areas of interest in the field of the social sciences.

8. Research reports.

9. Government gazettes: these are only purchased from a few countries at present, although older collections have been kept and are available for scrutiny in the Nordic Africa Institute Library. 


\section{Official publications on the Internet}

The two most important websites for official publications on the Internet are: African governments on the $W W W$ and African governments on the Internet. The former, a German site, is very user-friendly. Here, each country can be reached via an entry page on which links can be selected that lead to individual ministries, various authorities, embassies, central banks, the media, etc. This site was created in 1995 and is updated frequently. The latter, African governments on the Internet, is produced by UNECA (United Nations Economic Commission for Africa), and is very much like the former website, with entry points to each country. Here, links are given to strategy documents, planning programmes and projects within the IT sector.

The World Bank has a very useful website containing surveys and their follow-ups, which deal with poverty. This site contains some 3000 full text documents and is called Poverty in Africa. The name is somewhat misleading, however, since it gives little indication of how comprehensive the collection of official publications on the site actually is. Most of the documents are copied (scanned) from the original documents. Older material can also be found here in the form of statistics of various types, household surveys, censuses, and more. The most interesting collections concern countries such as Angola, Mali, Benin and São Tomé e Príncipe countries on which it is generally hard to find documentation. Algeria, Egypt, Libya, Tunisia and Réunion are not included, however.

Another important website belongs to the International Monetary Fund (IMF). Here, collections of documents are available under the heading, Poverty reduction strategy papers (PRSP), prepared in cooperation with the governments of the respective countries. These publications give concrete pictures of the macroeconomic conditions, together with structural and social action programmes for reducing poverty. There is a collection of current statistics within the different areas. The material is updated every third year, with data being available for most of the countries. At present, countries in North Africa are not included, and neither are Botswana, Gabon, Namibia, Nigeria and Zimbabwe.

Demographic and Health Surveys is a website produced by the U.S. Agency for International Development (USAID). At this site one can find official documents and statistics concerning population, health and nutrition in most of Africa's countries.

The website Political Resources also contains a number of links to official publications. An interesting website, Investir en zone franc, exists for French-speaking Africa, which supplies current development plans for many of these countries.

Constitutions can also be found on the Internet, three useful websites for these being: Constitution Finder, Constitutions of theWorld and A-Z World Constitutions (Charter 88). Under Law Library of Congress there are links to various relevant websites. The Washburn University School of Law 
Library also has a good link collection under the heading Constitutional law. If particular constitutions cannot be found on these websites, it is always possible to try search engines such as Google. Here, for example, on entering "The Constitution of The United Republic of Tanzania 1977", the address, http://kituochakatiba.co.ug/TanzaniaConstitution. pdf, will be reached, where the above-mentioned constitution can be recovered in full text.

It is also possible to find different parliamentary documents, bills and other documents, together with legislative collections, on the Internet. There are a number of interesting documents from Parliament of the Republic of Uganda, among others. In addition, a great deal of useful information can be found on the website, Parliament of South Africa, while an interesting collection of White Papers from and including 1994, are available at South Africa Government online.

\section{Statistics on the Internet}

In the Nordic Africa Institute's link collection A Guide to Africa on the Internet, links to the central statistical bureaus of different countries are available under the heading, Country specific information sources. Development has been rapid and many new links have been added to the Net in recent months. In fact, more than 20 states are now represented here. Besides the purely statistical data available in Statistics South Africa, publications such as Census in brief, Living in South Africa and Statistics in brief 2002, also provide useful information. In addition, there are a number of publications on different subjects, which incorporate statistics. A number of these that can be located online are: Measuring poverty in South Africa, Women and men in SA, Youth of SA, etc. Today, by entering 2002 Population and housing census results in Tanzania's National bureau of statistics, the latest Household Budget survey (2000/01.. It is also worth visiting Uganda Bureau of Statistics. Here, besides various current statistical publications, Uganda 2002 population census is also available. Instituto Nacional de Estatística in Mozambique publishes Census 97, in full text. A collection of all African National Statistics Offices can be found on the website Poverty in Africa (The World Bank Group).

\section{References}

Nucombe, Valerie, J. (Ed.) 1997 Information sources in official publications. London: Bowker Sauer.

Westfall, Gloria, 1997, Guide to official publications of foreign countries.Washington DC and Chicago: CIS and American Library Association. 


\section{Web resources}

African governments on the Internet - www.uneca.org/aisi/africagovinternet.htm

African governments on the WWW - www.gksoft.com/govt/en/africa.html

Demographic and health surveys - www.measuredhs.com/countries/start.cfm

Political resources on the Internet - www.politicalresources.net

Investir en zone franc - www.izf.net/izf/Documentation

\section{Constitutions}

Constitution finder - http://confinder.richmond.edu/

Constitutional law - www.washlaw.edu/forint/alpha/c/constitutional law.htm

Constitutions of the world -

www.findlaw.com/01topics/06constitutional/03forconst/index.htm

Law Library of Congress - www.loc.gov/law/guide/multiref.html

\section{Parliaments}

Web sites of National Parliaments - www.ipu.org/english/parlweb.htm

Parliament of South Africa - www.parliament.gov.za

Parliament of the Republic of Uganda - www.parliament.go.ug

\section{National statistical bureaus}

African National Statistics Offices -

www.4worldbank.org/afr/poverty/partners/africa_stat_offices_en.cfm

Instituto Nacional de Estatística (Moçambique) - www.ine.gov.mz

National Bureau of Statistics (Tanzania) - www.tanzania.go.tz/statisticsf.htm

Statistics of South Africa - www.statssa.gov.za

Uganda Bureau of Statistics - www.ubos.org

\section{Alleviation of poverty}

Poverty in Africa - www.4.worldbank.org/afr/poverty/databank/docnav/default.cfm

Poverty reduction strategy papers - www.imf.org/external/index.htm 


\section{Tanzania}

The Official Tanzania National Website - www.tanzania.go.tz/

Tanzania on-line - www.tzonline.go.tz/

\section{South Africa}

South Africa government online. White papers - www.gov.za/whitepaper/index.html

National treasury - www.treasury.gov.za/main.htm 


\section{History}

\section{Tore Linné Eriksen}

\section{The history of Africa's history}

African history is an area of study that is undergoing rapid change. This has meant that the volume of literature has grown enormously over the past number of years, and that research questions and perspectives have undergone considerable revision. Not least important in this regard has been the growing number of African researchers in this field, even if the majority of published works continue to reflect a dominance of historians from the USA and from the former colonial powers. In the past it was common practice to divide historians into various schools or 'compartments', e.g.; conservative historians during the colonial era, nationalist historians during the period of decolonization, and more radical historians during the 1970s. A brief overview of this period is given in the article "Avkolonisering av afrikansk historie. Et historiografisk riss" (Eriksen 1983). The lines of demarcation are nowadays significantly less well defined, even if discords over approaches and the selection of material remain. Nowadays it is more common to classify historians according to fields of research and choice of themes. Not the least important here has been the growth over recent years of a wealth of literature in the fields of social history, gender history, and environmental history. In order to illustrate these new departures in historical research, the following overview places special emphasis on books that have resulted from these trends. It is important to add, however, that specific regions do have their own distinctive features. For example, for the case of research on the history of Southern Africa, questions relating to land appropriation, racism, repression, and liberation movements have been of central importance.

The Norwegian historian Randi Rønning Balsvik has written Afrika i eit historiografisk perspektiv (2004) which is an excellent overview of themes and recent trends in the writing of African history, i.e. what is called a historiography. David Birmingham (1997) has written a concise article with a similar purpose. Useful historiographic introductions are to be found in a number of more straightforward overview works, such as Elisabeth Ischei's A history of African societies to 1870 (1997), and William Beinart \& JoAnn McGregor's Social history \& African environments (2003). A number of books present detailed bibliographical essays; a prominent example being Bill Freund's The making of contemporary Africa (1998). The particular characteristics of South African historiography are discussed in detail in South Africa's racial past written by Paul Maylam (2001). Tradition and change in Africa, is a collection of articles by the prominent Nigerian historian J.F. Ade Ajayi, includes many contributions concerning the history 
of historical research. This book is published by Africa World Press (Trenton, New Jersey), which has also published a series of collected works by other leading African historians including Bethwell A. Ogot (2002). The same publishers have also published a number of anthologies and festschrifts dedicated to historians such as Adu Boahen (Faloloa 2003b) and Toyin Falola (Oyebade 2003). Separate chapters are dedicated to a large number of African historians in The dark webs (Falola 2005). The work produced by nationalist historians in the 1960s is presented in an engaging manner in Nationalism and African intellectuals (Falola 2001). Rethinking African history (McGrath 1997) is an anthology of articles concerning the discipline of history that were presented at an international conference. Various perspectives on historical themes and research questions are collected in three anthologies edited by Robert O. Collins (1993, 1994, 1997), which deal with Africa's history preceding, during and following the colonial era respectively. The series entitled The Oxford history of the British Empire includes a volume entitled 'Historiography' (Winks 1999) in which an array of prominent historians contribute historiographic analyses of important aspects of British colonialism in Africa. Resistance, a further central theme of research, is presented in a multifaceted manner in Abbink's (2002) Rethinking resistance, while Sources and methods in African history (Falola \& Jennings 2003) provides a good account of research methodology (archaeology, written documentation, oral testimonies etc.)

\section{Atlases and reference books}

Concerning atlases of African history, nothing can compete with the impressive and comprehensive Historical atlas of Africa edited by J.F.A. Ajayi and M. Crowder (1985). A useful atlas in a smaller format is The Penguin Atlas of African History by McEvedy (1995).

Two large reference books on African history have recently been published. Key events in African history (Falola 2002c) is written by a single author and includes articles on more than thirty central events and processes in African history. While the book is a reference book, it can also be profitably read as an ordinary textbook. The twentieth-century is covered by 250 informative entries in the Encyclopaedia of twentieth-century African history, edited by Paul T. Zeleza \& Dickson Eyoh (2003). Also available are good reference books specifically concerning pre-colonial history (Collins 2001) and crises and conflicts (Arnold 2000). The Dictionary of African historical biography (Lipschultz \& Rasmussen 1986) is a concise biographical encyclopaedia. A selection of biographies can also be found in Pan-African history (Sherwood \& Adi 2003).

Concerning African historical dictionaries, a large number of volumes are now available that cover individual countries and which catalogue people, historical events, ethnic groups, organisations etc. These represent invaluable 
sources for those wishing to study specific countries, and include comprehensive bibliographies. In most cases, these dictionaries are continually revised in the form of new editions. Among the countries that have been covered by publications in recent years, worthy of note are those on Congo-Kinshasa/Zaire (Bobb 1999), Liberia (Dunn 2001), Malawi (Kalinga \& Crosby 2002), Mozambique (Azevedo 2003), Nigeria (Oyewole 2000), Sudan (Lobban 2002), South Africa (Saunders \& Southey 2000), and Zimbabwe (Rupert \& Rasmussen 2001).

\section{Overviews}

While they are by no means the most recently published works, two comprehensive publications, each comprising eight volumes with a wide range of contributions by prominent historians, continue to represent important works of reference for the study of African history from the earliest times up to the present day. The Cambridge history of Africa was completed in 1986, while the final volume of UNESCO's A general history of Africa was published in 1993. A feature of the latter work is that it includes a larger number of contributions by authors from the African continent, including A. Adu Boahen, Bethwell A. Ogot, and Joseph Ki-Zerbo as central editors and authors. All of the volumes in the UNESCO series are also available in more accessible and cheaper abridged editions. Over the course of the past few years a group of historians, most of them originating from Africa, have jointly compiled a five-volume 3000-page work entitled Africa. The chapters are both thematically and regionally organised, and all of the volumes are edited by the Nigerian historian Toyin Falola (Falola 2000a, 2000b, 2002a, 2003). This series, which serves as a most useful introduction both for students and for those with a general interest in the subject area, has recently been completed and is expected to assume a position of central importance both within and outside academia.

Many Scandinavians have been introduced to African history by watching Basil Davidson's classic t.v-series, which subsequently formed the basis for his book The story of Africa (1984). As a populariser of African history, Davidson is in a class of his own, and many of his books have been translated into Nordic languages. Among others, these include his presentation of modern African history: Modern Africa: A social and political history (1994b), which is also available in a revised edition in Swedish. In The black man's burden (1992) Davidson argues that the imported colonial- and national-state form constitutes one of Africa's central problems. The search for Africa (1994) is a collection of articles concerning both historical and contemporary themes, while Africa in history (2001) is a revised edition of Davidson's classic study. Another populariser of this field who deservedly enjoys a wide readership is John Reader. He has authored Africa: A bibliography of the continent (1997). 
There are many other books to choose from for students looking for a concise introduction to Africa's history. An excellent place to start is John Iliffe's The Africans (1995) which is also available in Swedish. Iliffe has also written a thorough account of the history of poverty (1987), as well as a study of the concept of 'honour' in African history (2004). The most widely used textbooks in the United States have, for a number of years, been African history by Phillip Curtin et al. (1995) and A history of the African people by Robert W. July (1997). A new and highly recommended book serving the same audience is Africa in world history. From prehistory to the present, written by Jonathan T. Reynolds and Eric Gilbert (2004). Among the good introductions by British historians are John Fage and William Tordoff's $A$ history of Africa (2001) and Roland Oliver's The African experience (1991). Roland Oliver has, together with Anthony Atmore, also written Medieval Africa, 1250-1800 (2001) and Africa since 1800 (2005). A Nordic textbook in this field is Jarle Simensen's Afrikas historie (2004). A concise introduction to Africa's history for students at upper-secondary and high school levels is Kevin Shillington's A history of Africa (1995).

Although it does not incorporate the latest research findings, Ralph Austen's African economic history (1987) retains an unchallenged position in the field of economic history. The Malawian historian Paul T. Zeleza is currently working on a two-volume economic history of the period 18002000, although only the first of these volumes entitled A modern history of Africa. Volume 1: The nineteenth century (1993) has as yet been published. Despite it being more than thirty years since its initial publication, Walter Rodney's classic How Europe underdeveloped Africa from 1972 continues to be widely read. The book is essentially a contribution to the debate concerning the devastation caused by the European slave trade, resource exploitation and extraction, colonialism, and the West's continued economic hegemony.

As a response to the large and still growing field of local studies on environmental history, James McCann (1999) has written an overview entitled: Green land, brown land, black land: An environmental history of Africa, 1800-1990. A recent anthology of articles that integrates social and environmental history is Social history \& African environments (Beinart \& McGregor 2003). Standard works in the field of the historical study of women include African women. A modern history (Coquery-Vidrovitch 1997), and Women in sub-Saharan Africa: Restoring women to history (Berger \& White 1995). A number of anthologies of collected articles have also explored the history of African women, more usually with a focus on the colonial era, such as Allman (2002) and Hunt (1997).

Important written source material for understanding African history has been collected by Robert O. Collins in Documents from the African past (2001). This has built on an earlier and more comprehensive collection of documentation arranged on a regional basis (Collins 1990a, b, and c). Worger's (2001) Africa and the West is a collection of source materials concerned with the relations between Africa and the West in an historical 
perspective. Barbara Harlow and Mia Carter (2003) have edited a rich collection of written material illustrating Great Britain's role in the scramble to colonise Africa.

\section{Pre-colonial history}

The literature concerning pre-colonial Africa is becoming increasingly rich as a result of knowledge gained from archaeological excavation, environmental studies, language studies, and from oral sources. This is well demonstrated in A history of African societies to 1870 , written by the Nigerian historian Elizabeth Isichei (1997). The same author has written Voices of the poor in Africa (2002), in which she examines myths and systems of belief among Africans as a means of giving voice to those who are otherwise rarely heard in historical research. The latest research is presented in a pedagogic manner in Christopher Ehret's The civilizations of Africa: A history to 1800 (2002). This book also distinguishes itself by discussing Africa's early history in a global perspective. For those wishing to deepen their understanding of the history of the earliest times, Ehret's (1998) study of the history of Eastern and Southern Africa up to circa 400 A.D. is recommended. Peter Mitchell's African connections is an outstanding survey of pre-colonial history from a British archaeologist who is especially interested in documenting Africa's connections with other parts of the world. An overview of the earliest civilisations is provided in Graham Connah's African civilizations (2001). The same author also introduces contemporary archaeological research in a well-written and accessible manner in Forgotten Africa (2004). An engaging account of pre-colonial history that emphasises the relations between human being and the natural environment, is provided by the geographer James L. Newman in his The peopling of Africa (1995).

Not unexpectedly, the slave trade and its consequences have received considerable attention in research concerning pre-colonial African society. Here there is much to choose from, both in terms of local studies and more general overviews. In the latter category, three books deserve particular mention: Slavery and African lives (Manning 1990), The Atlantic slave trade (Klein 1999) and Transformations in slavery (Lovejoy 2000). In An African life James Walvin (1998) explores the history of slavery through the biography of Olaudah Equinios. Drawing from contemporary written sources of the age, Anne C. Bailey (2005) has presented African perspectives on the slave trade. The era of the slave trade also has a prominent position in a recent study on the history of Africans outside the African continent (Gomez 2005). While these books are mainly concerned with the trans-Atlantic slave trade, Ronald Segal's Islam's black slaves (2002) provides an accessible overview of the slave trade to the Islamic world. In his Africans and the industrial revolution in England, Joseph E. Inikori (2002) emphasises the central role played by African slave labour in the history of economic 
development in the West. In Africa and Africans in the making of the Atlantic world 1400-1800, John Thornton (1998) illustrates the importance of studying African history in order to be able to understand the development of 'the Atlantic world'. The same author (Thornton 1999) has also documented the disastrous consequences of war and conflict during the era of slave trade. The life histories of women during the slave trade is a theme taken up in Strategies of slaves and women (Wright 1993). Africa's discovery of Europe (Northrup 2002) is an innovative introduction to African's encounter with Europe in the period before 1850.

\section{The colonial era and decolonization}

Of the general surveys of more recent African history, there is special reason to mention Bill Freund's The making of contemporary Africa (1998), which covers the period from the beginning of the $19^{\text {th }}$ century. A more thematic discussion is given in Africa: Endurance and change South of the Sahara written by one of the foremost of French historians, Catherine CoqueryVidrovitch (1988). The same author has recently given an historical account of urbanisation and urban life in Africa (2005), a theme that also constitutes the focus in an informative collection of articles edited by Anderson and Rathbone (2000).

Another theme that has received considerable attention is 'the partition of Africa' and the colonial system. The best academic historical study about partition is Wesseling's Divide and rule (1996), but many readers can also benefit from Thomas Pakenham's popular historical account entitled The partition of Africa (1991). Vandervort (1998) provides an historical perspective on the subject of warfare during the period of conquest. It is no surprise that there is a wealth of literature on colonialism and its effects. A good starting point is African perspectives on colonialism in which the prominent Ghanaian historian A. Adu Boahen summarises his own views on the colonial era in an engaging and concise overview (1989). Summaries of a range of perspectives on colonialism are also collected in The colonial moment in Africa edited by Andrew Roberts (1991). A standard work on the colonial state in Africa, which shows how many of the problems currently afflicting Africa have their roots in the colonial past, is Crawford Young's The African colonial state in comparative perspectives (1994). The territories that came under British colonial administration are dealt with in a large number of articles in the five-volumes of The Oxford history of the British Empire (1998, 1999), and in a supplementary volume on the history of African peoples during Empire with special emphasis on the slave trade and the colonial era (Morgan \& Hawkins 2004). The dark webs (Falola 2005) is a highly informative and well-written collection of articles that discusses important themes of research concerning the history of colonialism. Africa's history during the early phase of colonialism is a central theme in The 
European colonial empires 1815-1919 (Wesseling 2004). Concerning the French colonial territories, an excellent overview work, which also traces the history up to the present day, is Francophone sub-Saharan Africa 1880-1995 (Manning 1999). Barbara Bush provides an exciting discussion of some central aspects of British colonial history in Imperialism, race and resistance (1999). Social history during the colonial era is the theme of a large number of books in the series entitled Social history in Africa (Oxford: James Currey). such as Cotton, colonialism and social history (Isaacman \& Roberts 1995).

The most comprehensive introduction to African history after independence is Paul Nugent's Africa since independence (2004) while Martin Meredith offers a wealth of useful information in The state of Africa (2005). The most recent history is also covered in Frederick Cooper's wellwritten and informative textbook entitled Africa since 1940 (2002). The same author has written an exhaustive study of the history of decolonization (1996). David Birmingham's The decolonisation of Africa (1993) is a short and concise account of the period of decolonisation. The same author has also explored the African liberation struggle in the form of a biography of Kwame Nkrumah (Birmingham 1998). Birmingham has also examined frontline nationalism in Angola and Mozambique (Birmingham 1992). Another good overview of African decolonisation is written by H.S. Wilson (1994). A history of the liberation of the Portuguese colonies is written by Norrie MacQueen (1997). Nationalist ideology and frontline nationalism, with a particular focus on the role of intellectuals, is approached in a fascinating manner by Toyin Falola (2001).

\section{Regions and individual countries}

\section{Southern Africa}

In terms of concise introductions to the history of the whole of southern Africa, two recommended works are A new history of southern Africa (Parsons 1993) and A history of southern Africa (Omer-Cooper 1997). Specifically concerning South Africa there is no lack of good textbooks, the most popular being History of South Africa (Thompson 2001), South Africa. A modern history (Davenport \& Saunders 2000), and more abridged works including A concise history of South Africa (Ross 1999), The history of South Africa (Beck 2000), The making of modern South Africa (Worden 2000), and South Africa. The first man, the last nation (Johnson 2004). A well-written survey of the history of the last century is Twentieth-century South Africa (Beinart 2001). The seed is mine (Van Onselen 1996) is already a classic and illuminates the entire $20^{\text {th }}$ century with a well-documented presentation of an African family. In The Afrikaners, Hermann Giliomee (2003) has sketched an historical portrait of the Afrikaner Boers. A history of inequality in South Africa 1652-2002 (Terreblanche 2003) focuses on inequality and repression 
over a long time period. The Boer War has engaged a large number of historians and among the best recent books on this topic are those by Nasson (1999), Jackson (1999) and Judd and Surridge (2002). The rise and fall of apartheid is the focus of a wealth of books, and good introductions to this topic are to be found in Forty years lost (O’Meara 2000) and in South Africa. The rise and fall of apartheid (Clark \& Worger 2003). The history of the ANC is concisely introduced by Dubow (2000), while the history of the United Democratic Front (UDC) is the focus of attention for two thorough studies by Seekings (2000) and Van Kessel (2000). From protest to challenge. A documentary history of African politics in South Africa is the title of a book series that comprehensively documents resistance, nationalist and liberation struggles in South Africa. The fifth volume deals with the period from 1964 to 1979 (Karis \& Gerhart 1997). The period after 1990 is covered in books described in the 'Politics and economy' chapter of this publication.

The environmental history of southern Africa is an area of study that has attracted a growing number of historians. The best anthology is South Africa's environmental history (Dovers 2003). A well researched case study is The rise of conservation in South Africa (Beinart 2003). Environment and history (Beinart \& Coates 1995) is a comparative work on the environmental histories of South Africa and the United States.

The role played by the Nordic countries in the liberation of southern Africa has been the subject of an exhaustive research project directed by the Nordic Africa Institute. The findings from this project are published in a series of detailed studies (Eriksen 2000; Sellström 1999a; Sellström 1999b; Sellström 2002; Soiri \& Peltola 1999 and Morgenstierne 2003). Aside from South Africa, few other countries in the region have been the subject of recent historical overviews, one notable exception being A history of Mozambique (Newitt 1995). Kathleen E. Sheldon (2002) examines the role of women in the history of Mozambique in a fascinating manner, while Allen Isaacman (1996) illustrates the history of colonialism with examples drawn from agriculture. Heywood (2000) examines important aspects of the history of Angola from the mid-19th century. Together with other countries in Lusophone Africa, the history of decolonisation and the postcolonial era in Angola and Mozambique is concisely rendered in History of postcolonial lusophone Africa (Chabal 2002). The history of the Herero population in Namibia and the history of German acts of genocide during the early twentieth century are examined in Jan-Bart Gewald's Herero heroes (1999), while the period of South African occupation is covered by Patricia Hayes (1998). Nationalism, the liberation struggle and decolonisation are examined by, among others, Dobell (1998), Emmett (1999), Leys \& Saul (1995), and Leys \& Brown (2005). A standard work on the Shona, Zimbabwe's largest ethnic group, which is maily concerned with the pre-colonial era is David Beach's The Shona and their neighbours (1994), while both Elizabeth Schmidt (1992) and Terese Barnes (1999) focus on women's history during the colonial era. Voices from the rocks (Ranger 1999) and Violence \& 
memory (Alexander 2000) are two engaging case studies from southwestern Zimbabwe. A historical perspective on issues concerning democratisation and human rights can be found in Bhebe \& Ranger (2001). Rural everyday life in Malawi during the colonial era is the focus of attention in Work and control in a peasant economy (Mandala 1990), a book which has justifiably received considerable international acclaim. A further classic work on Malawi, which combines environmental, agricultural, and women's history, is The story of an African famine (Vaughan 1987). With examples drawn from Zambia, the same theme is examined in an engaging manner by Moore \& Vaughan (1994). Guardians in their time is a collection of articles that relates histories of the common Zambian during the colonial era (Chipungu 1992). Epprecht (2000) provides an important contribution to the study of Lesotho's history.

\section{East Africa and the Horn of Africa}

For a single volume covering the East African region as a whole in the period 1592-1902 see Beachey (1995). A long-term historical perspective also characterises Horton \& Middleton's The Swahili (2001). Concerning studies on individual countries, a study which still lacks equals is John Iliffe's voluminous A modern history of Tanganyika (1979). The German colonial era up to W.W.I is covered in detail by Juhani Koponen (1994), while Zanzibar during the colonial period is explored in a collection of articles (Sheriff \& Ferguson 1991). The Tanzanian historian Isaria N. Kimambo (1991) has traced the local history of Pare District against the background of world history over the past century. Tanzania also distinguishes itself in terms of the wealth of available literature on environmental history. Pioneering studies in this field include Ecology control and economic development in East African history, written by the Norwegian social scientist Helge Kjekshus (1996). The latest edition of this book includes a detailed review of environmental history research. People - nature relations are similarly the central focus of study in Giblin (1992) and Maddox (1996). Exciting studies on environmental history in the Kenyan context have also been published in recent years. Foremost among these are Eroding the commons (Anderson 2002), and Land, ecology and resistance (Mackenzie 1998). Kenya's economic history is examined by a number of authors in An economic history of Kenya (Ochieng \& Maxon 1992). Voices from Mutira (Davison 1994) deals with women's living conditions in Kenya with a special emphasis on the Kikuyu people. Central aspects relating to colonial history, with an emphasis on the struggle for land, are examined in detail in a twovolume work entitled Unhappy Valley. Conflict in Kenya \& Africa by Bruce Berman \& John Lonsdale (1992). The struggle for land and liberty in the context of the Mau Mau uprising is considered in a wide spectrum of literature. The most recent research on this politically and historically contested theme is examined in the anthology entitled Mau Mau \& Nationhood (Odhiambo \& Lonsdale 2003). The British warfare is examined in detail by Carol Elkins in Britain's Gulag (2005) and by David Anderson in 
Histories of the hanged (2005). Other recommended individual studies include Clough (1998), Otieno \& Presley (1998), Kershaw (1997), Presley (1992), Furedi (1989), and Throup (1987). The history of the transition to independence is examined in a comprehensive collection of articles entitled Decolonization \& independence in Kenya (Ogot \& Ochieng 1995). Concerning countries in the Horn of Africa, a region usually considered a part of eastern Africa, a number of books on Ethiopian history are available, including The Ethiopians (Pankhurst 1998), and A history of Ethiopia (Marcus 2002). The history of Ethiopia during the last century is the focus of A history of modern Ethiopia (Zewde 2001). A standard work on Somalia's recent history is A modern history of the Somali authored by I.M. Lewis' (2002).

\section{Central Africa}

The standard work on the history of Central Africa is the three-volume work entitled History of Central Africa. Here, region is defined in a way which includes countries more usually considered as belonging to southern Africa, such as Angola, Zambia and Zimbabwe. The first two volumes were published in the 1980s (Birmingham \& Martin 1983) and cover the period up to circa 1960. The following decade is covered in volume three (Birmingham \& Martin, 1998). Concerning the individual countries in the region, there is a particularly large body of literature on the history of Congo-Kinshasa/Zaire, such as The troubled heart of Africa: A history of Congo (Edgerton 2002). Adam Hochschild (1999) has achieved considerable international acclaim with his account of colonialism and brutal oppression in King Leopold's ghost. This book has subsequently been translated into a number of Nordic languages. The Congo from Leopold to Kabila is a comprehensive history which discusses both colonialism and the reign of terror during the Mobutu era (Nzongola-Ntalaja 2002). A well-documented study of decolonization and the murder of President Patrice Lumumba is The assassination of Lumumba (De Witte 2001). Giles-Vernick (2002) provides an overview of the environmental history of the Central African rainforests. Rwanda and Burundi are situated at the confluence of Central and Eastern Africa, and together with parts of Uganda, Tanzania and Congo are considered in The great lakes of Africa (Crétien 2003), which employs a 2000 year perspective. A retrospective historical consideration of both the colonial era and the period of decolonization is related in The Rwanda crisis, written by the French historian Gérard Prunier (1995).

\section{West Africa}

The two-volume History of West Africa (Ajayi \& Crowder 1985, 1987) has long been considered a standard work of reference on West African history. A more recent overview of the region, however, is West Africa: An introduction to its history, civilisation and contemporary situation 
(Mendonsa 2002). A new edition of Basil Davidson's West Africa before the colonial era (1998) specifically concerns the history of the region up to 1850. The slave trade and the system of slavery are examined in detail by Martin A. Klein (1998). A new edition of the classic An economic history of West Africa (Hopkins 1973) is expected to be published in 2005. A series of articles concerning the transition from the slave trade to production for the world market in the nineteenth century is collected in From slave trade to 'legitimate commerce' (Law 1995). West African responses to European imperialism in the nineteenth and twentieth centuries (Ohaegbulam 2002) focuses upon a central theme in West African history. West African challenge to empire (Saul \& Royer 2001) is an exciting study of the widespread uprising in Volta-Bani during the First World War. A women's perspective on Ghanaian history is presented in 'I will not eat alone': A woman's history of colonial Asante (Allmann \& Tashjian 1999).

Important aspects of the British colonial system in West Africa are examined by Anne Phillips (1989). As is mentioned above, the greater part of West Africa that fell under French colonial rule has been concisely examined for the period 1880-1995 (Manning 1998). The same author has also written Slavery, colonialism and economic growth in Dahomey, 1640-1960, with particular emphasis on the place of Dahomey in the world economy (Manning 2004). A large number of books have illuminated Nigeria's past. A good starting point for those who need a concise overview is The history of Nigeria, written by the Nigerian historian Toyin Falola (1999). A large group of historians have collaborated in the compilation of a very comprehensive collection of articles that examines Nigeria's twentieth century history (Falola 2002d).

A growing number of historians and anthropologists have, over recent years, argued that local African societies can only be understood when situated in a global and historical perspective. An excellent example is The world and a very small place in Africa, in which Donald R. Wright (2004) traces the history of the Niumi region of The Gambia by concentrating on the spread of Islam across the Sahara, the slave trade, colonialism and nationalism. His study integrates the history of everyday life and global forces in an interesting manner. Mendonsa (2001) employs a similar approach with examples drawn from the Sisala society in Ghana.

\section{North Africa and the Middle East}

Many regions of the African continent are included in general overviews of the Middle East and in histories of the Arab peoples. One of the standard textbooks which deals with the period beginning from the oldest civilisations, and which has been published in continually updated editions, is Arthur Goldschmidt's A concise history of the Middle East (2003). Another popular textbook, but which concentrates on the past two hundred-year period, is $A$ history of the Middle East (Cleveland 2000). The history of the Arab peoples is examined in two standard works: A history of the Arab peoples (Hourani 
2002), and History of the Arabs (Hitti 2002). Barnaby Rogerson (1998) concisely covers the history of North Africa (Algeria, Morocco, Tunisia and Libya). Two new standard works on the economic history of the Middle East are The Middle East in the world economy 1800-1914 (Owen 1993) and A history of Middle East economies in the $20^{\text {th }}$ century (Owen \& Pamuk 1998).

One can easily get lost in the wealth of literature that has been published on various aspects of Egypt's long history. A concise overview for newcomers is Egypt: A short history, written by James Jankowski (2000). A concise classic work covering the period after 600 A.D. is A short history of modern Egypt (Marsot 1985). For those who are interested in more recent history, a recommended work is Arthur Goldschmidt's Modern Egypt (2003). The history of the Egyptian people from the time of the Pharaohs is lucidly examined by Barbara Watterson in The Egyptians (1997). Modern Algeria (Ageron 1991), The making of contemporary Algeria (Bennoune 2002), and Algeria 1830-2000 (Stora 2001) cover the period from 1830 up to the era following decolonization. A gender perspective on Algerian history is presented in Marnia Lazreg's The eloquence of silence (1994). The history of the Berbers is comprehensively covered in The Berbers (Brett \& Fentress 1996). A newly published study that deals with the history of Tunisia from the mid- $19^{\text {th }}$ century onwards is A history of modern Tunisia (Perkins 2004). For a good overview of Morocco's history see C.R. Pennell's Morocco. From empire to independence (2003). The modern standard work on the history of Sudan is written by Holt \& Daly (2000) and is now in its fifth edition. A very pertinent study on the historical roots of an ongoing conflict is The root causes of Sudan's civil wars, written by Douglas H. Johnson (2003). In The River Nile in the age of the British (Tvedt 2004), the Norwegian historian provides an insights into the struggle for control of the world's longest river. The history of the Nile over an even longer period of time is examined by Robert O. Collins in The Nile (2002).

\section{References}

Abbink, Jon et al.eds (2003) Rethinking resistance. Revolt and violence in African history. Leiden: Brill.

Ageron, Charles-Robert (1991) Modern Algeria. A history from 1830 to the present. London: C. Hurst \& Co.

Ajayi, J.F. Ade \& Michael Crowder, eds (1985) Historical atlas of Africa. London: Longman.

Ajayi, J.F. Ade \& Michael Crowder, eds (1985) History of West Africa, vol. 1. London: Longman. 3. ed.

Ajayi, J.F. Ade \& Michael Crowder, eds (1987) History of West Africa, vol. 2. London: Longman. 2. ed. 
Ajayi, J.F. Ade (2000) Tradition and change. The essays of J.F. Ade Ajayi. Edited by T. Falola. Trenton: Africa World Press.

Alexander, Jocelyn et al. (2000) Violence \& memory. One hundred years in the 'dark forests of Matabeleland. Oxford: James Currey.

Allman, Jean \& Victoria Tashjian (2000) " I will not eat stone”. A women's history of colonial Asante. Portsmouth, New Hampshire: Heinemann.

Allman, Jean et al., eds (2002) Women in African colonial histories. Bloomington: Indiana University Press.

Anderson, David M. (2002) Eroding the commons. The politics of ecology in Baringo, Kenya 1890s-1963. Oxford: James Currey.

Anderson, David M. (2005) Histories of the hanged. Britain's dirty war in Kenya and the end of empire. London: Weidenfeld \& Nicolson.

Anderson, David M. \& Richard Rathbone, eds (2000) Africa's urban past. Oxford: James Currey.

Arnold, Guy (1999) Historical dictionary of civil wars in Africa. Lanham: Scarecrow Press.

Austen, Ralph (1987) African economic history. Internal development and external dependency. London: James Currey.

Azevedo, Mario et al. (2003) Historical dictionary of Mozambique. Lanham: Scarecrow Press. 2. ed.

Bailey, Anne C. (2005) African voices of the Atlantic slave trade. Beyond the silence and shame. Boston: Beacon Press.

Balsvik, Randi Rønning (2004) Afrika i eit historiografisk perspektiv. Oslo: Det Norske Samlaget.

Barnes, Teresa A. (1999) "We women worked so hard". Gender, urbanization \& social reproduction in colonial Harare, Zimbabwe 1930-1956. Oxford: James Currey.

Beach, David (1994) The Shona and their neighbours. Oxford: Blackwell.

Beachey, R.W. (1996) A history of East Africa 1592-1902. London: I.B. Tauris.

Beck, Roger B. (2000) The history of South Africa. Westport, Connecticut/London: Greenwood Press.

Beinart, William \& Peter Coates (1995) Environment and history. The taming of nature in the USA and South Africa. London: Routledge.

Beinart, William (2001) Twentieth-century South Africa. Oxford: Oxford University Press. 2. ed.

Beinart, William (2003) The rise of conservation in South Africa. Settlers, livestock and the environment 1770-1950. Oxford: Oxford University Press.

Beinart, William \& JoAnn McGregor, eds (2003) Social history \& African environments. Oxford: James Currey. 
Bennoune, Mahfoud (1988) The making of contemporary Algeria, 1830-1987. Colonial upheavals and post-independence development. Cambridge: Cambridge University Press. (Paperback 2002.)

Berger, Iris \& E. Frances White (1999) Women in sub-Saharan Africa. Restoring women to history. Bloomington: Indiana University Press.

Berman, Bruce \& John Lonsdale (1992) Unhappy valley. Conflict in Kenya \& Africa. Vol 1-2. London: James Currey.

Bhebe, Ngwabi \& Terence Ranger, eds (2001) Historical dimensions of democracy and human rights in Zimbabwe. vol 1: Pre-colonial and colonial legacies. Harare: Zimbabwe University Publications.

Birmingham, David (1992) Frontline nationalism in Angola \& Mozambique. London: James Currey.

Birmingham, David (1995) The decolonization of Africa. London: UCL Press.

Birmingham, David (1997) "History in Africa” in Michael Bentley, ed. Companion to historiography. London: Routledge.

Birmingham, David (1998) Kwame Nkrumah. The father of African nationalism. Athens: Ohio University Press. 2. ed.

Birmingham, David \& Phyllis M. Martin, eds (1983) History of Central Africa, vol. 1-2. London: Longman.

Birmingham, David \& Phyllis M. Martin, eds (1998) History of Central Africa, vol. 3: The contemporary years since 1960. London: Longman.

Boahen, A. Adu (1989) African perspectives on colonialism. London: James Currey.

Bobb, F. Scott (1999) Historical dictionary of Democratic Republic of the Congo (Zaire). Lanham: Scarecrow Press.

Brett, Michael \& Elizabeth Fentress (1996) The Berbers. Oxford: Blackwell.

Bush, Barbara (1999) Imperialism, race and resistance. Africa and Britain 19191945. London: Routledge.

The Cambridge history of Africa, vol. 1-8 (1975-1986). Cambridge: Cambridge University Press.

Chabal, Patrick et al. (2002) A history of postcolonial Lusophone Africa. Bloomington: Indiana University Press.

Chafer, Tony (2002) The end of empire in French West Africa. France's successful decolonization? Oxford: Berg.

Chipungu, Samuel N., ed. (1992) Guardians in their time. Experiences of Zambians under colonial rule, 1890-1964. London: Macmillan.

Chretien, Jean-Pierre (2003) The great lakes of Africa. Two thousand years of history. New York: Zone Books.

Clark, Nany \& William H. Worger (2003) South Africa. The rise and fall of apartheid. Harlow: Longman.

Cleveland, William L. (2000) A history of the modern Middle East. Boulder/Oxford: Westview Press. 2. ed. 
Clough, Marshall S. (1998) Mau Mau memoirs. History, memory, and politics. Boulder/London: Lynne Rienner.

Collins, Robert O., ed. (1990 a) Western African history. Princeton: Markus Wiener Publishers.

Collins, Robert O., ed. (1990 b) Eastern African history. Princeton: Markus Wiener Publishers.

Collins, Robert O., ed. (1990 c) Central and South African history. Princeton: Markus Wiener.

Collins, Robert O., ed. (1993) Problems in African history. The pre-colonial centuries. Princeton: Markus Wiener Publishers.

Collins, Robert O. et al., eds (1994) Historical problems of imperial Africa. Princeton: Markus Wiener Publishers.

Collins, Robert O. et al. (1997) Problems in the history of modern Africa. Princeton: Markus Wiener Publishers.

Collins, Robert O. (2001a) Historical dictionary of pre-colonial Africa. Lanham: Scarecrow Press.

Collins, Robert O., ed. (2001b) Documents from the African past. Princeton: Markus Wiener Publishers.

Collins, Robert O. (2002) The Nile. New Haven/London: Yale University Press.

Connah, Graham (2001) African civilizations. An archeological perspective. Cambridge: Cambridge University Press. 2. ed.

Connah, Graham (2004) Forgotten Africa. An introduction to its archeology. London: Routledge.

Cooper, Frederick (1996) Decolonization and African society. The labor question in French and British Africa. Cambridge: Cambridge University Press.

Cooper, Frederick (2002) Africa since 1940. The past of the present. Cambridge: Cambridge University Press.

Coquery-Vidrovitch, Catherine (1988) Africa. Endurance and change south of the Sahara. Berkeley/Los Angeles/London: University of California Press. (Paperback 1992).

Coquery-Vidrovitch, Catherine (1997) African women. A modern history. Boulder/Oxford: Westview Press.

Coquery-Vidrovitch, Catherine (2005) History of Black African cities. Princeton: Markus Wiener Publishers.

Curtin, Philip et al. (1995) African history. From earliest times to independence. London: Longman. 2. ed.

Davenport, T.H.R. \& Christopher Saunders (2000) South Africa. A modern history. London: Palgrave Macmillan. 5. ed.

Davidson, Basil (1984) The story of Africa. London: Mitchell Beazley/Channel Four Books. (Swedish transl.: Afrika. En kontinents historia. Stockholm: Bonnier fakta, 1984.) 
Davidson, Basil (1992) The black man's burden. Africa and the curse of the nationstate. London: James Currey.

Davidson, Basil (1994a) The search for Africa. A history in the making. London: James Currey.

Davidson, Basil (1994b) Modern Africa. A social and political history. London: Longman. 3. ed. (Swedish transl.: Afrika i det tjugonde seklet. Uppsala: Nordiska Afrikainstitutet, 2001, rev. ed.)

Davidson, Basil (1998) West Africa before the colonial era. A history to 1850. London: Longman.

Davidson, Basil (2001) Africa in history. Themes and outlines. London: Phoenix Press. Rev. ed.

Davison, Jean (1996) Voices from Mutira. Change in the lives of rural Gikuyu women, 1910-95. Boulder/London: Lynne Rienner. 2. ed.

De Witte, Ludo (2001) The assassination of Lumumba. London: Verso Books. (Paperback 2002.)

Dobell, Lauren (1998) Swapo's struggle for Namibia, 1960-1991. Basel: P. Schlettwein Publishing.

Dovers, Stephen et al., eds (2003) South Africa's environmental history. Cases and comparisons. Athens: Ohio University Press.

Dubow, Saul (2000) The African National Congress. Stroud: Sutton.

Dunn, D. Elwood et al. (2001) Historical dictionary of Liberia. Lanham: Scarecrow Press. 2. ed.

Edgerton, Robert B. (2002) The troubled heart of Africa. A history of the Congo. New York: St. Martin's Press.

Ehret, Christopher (1998) An African classical age. Eastern and southern Africa in world history, 1000 BC to AD400. Oxford: James Currey. (Paperback 2001.)

Ehret, Christopher (2002) The civilizations of Africa. A history to 1800. Oxford: James Currey.

Elkins, Caroline (2005) Britain's Gulag. The brutal end of empire in Kenya. London: Jonathan Cape.

Emmett, Tony (1999) Popular resistance and the roots of nationalism in Namibia, 1915-1996. Basel: P. Schlettwein Publishing.

Epprecht, Marc (2000) "This matter of women is getting very bad". Gender, development and politics in colonial Lesotho. Pietermaritzburg: University of Natal Press.

Eriksen, Tore Linné (1983) “Avkolonisering av afrikansk historie. Et historigrafisk riss” in N. J. Ringdal, ed. Frontlinjer i historiefaget. Oslo: Universitetsforlaget.

Eriksen, Tore Linné, ed. (2000) Norway and national liberation in southern Africa. Uppsala: Nordiska Afrikainstitutet.

Fage John \& William Tordoff (2001) A history of Africa. London: Routledge. 4. ed. 
Falola, Toyin (1999) The history of Nigeria. Westport, Connecticut: Greenwood Press.

Falola, Toyin, ed. (2000a) Africa, vol. 1: African history before 1885. Durham: Carolina Academic Press.

Falola, Toyin, ed. (2000b) Africa, vol. 2: African cultures and societies before 1885. Durham: Carolina Academic Press.

Falola, Toyin (2001) Nationalism and African intellectuals. Rochester: University of Rochester Press/Woodbridge, Suffolk: Boydell \& Brewer. (Paperback 2003.)

Falola, Toyin, ed. (2002a) Africa, vol. 3: Colonial Africa 1885-1939. Durham: Carolina Academic Press.

Falola, Toyin, ed. (2002b) Africa, vol. 4: The end of colonial rule. Nationalism and decolonization. Durham: Carolina Academic Press.

Falola, Toyin (2002c) Key events in African history. A reference guide. Westport: Greenwood Press.

Falola, Toyin, ed. (2002d) Nigeria in the twentieth century. Durham: Carolina Acdemic Press.

Falola, Toyin, ed. (2003a) Africa, vol. 5: Contemporary Africa. Durham: Carolina Academic Press.

Falola, Toyin, ed. (2003b) Ghana in Africa and the world. Essays in honor of Adu Boahen. Trenton: Africa World Press.

Falola, Toyin, ed. (2005) The dark webs. Perspectives on colonialism in Africa. Durham: Carolina Academic Press.

Falola, Toyin \& Christian Jennings, eds (2003). Sources and methods in African history. Spoken, written, unearthed. Rochester: University of Rochester Press.

Freund, Bill (1998) The making of contemporary Africa. The development of African society since 1800. London: Macmillan. 2. ed.

Furedi, Frank (1989) The Mau Mau war in perspective. London: James Currey.

Gewald, Jan-Bart (1999) Herero heroes. A socio-political history of the Herero in Namibia. Oxford: James Currey.

Giblin, James L. (1992) The politics of environmental control in northeastern Tanzania, 1840-1940. Philadelphia: University of Pennsylvania Press.

Giles-Vernick, Tamara (2002) Cutting the vines of the past. Environmental histories of the Central African rain forest. Charlottesville: University Press of Virginia.

Giliomee, Hermann (2003) The Afrikaners. Biography of a people. London: C. Hurst \& Co.

Goldschmidt, Arthur Jr. (2002) A concise history of the Middle East. Boulder: Westview Press. 7. ed.

Goldschmidt, Arthur Jr. \& Robert Johnstone (2003a) Historical dictionary of Egypt. Lanham: Scarecrow Press. 3. ed.

Goldschmidt, Arthur Jr. (2003b) Modern Egypt. The formation of a nation-state. Boulder/Oxford: Westview Press. 2. ed. 
Gomez, Michael A. (2005) Reversing sail. A history of the African diaspora. Cambridge: Cambridge University Press.

Harlow, Barbara \& Mia Carter, eds (2003) Archives of empire, vol. 2: The scramble for Africa. Durham: Duke University Press.

Hayes, Patricia et al., eds (1998) Namibia under South African rule. Mobility \& containment 1915-46. Oxford: James Currey.

Henze, Paul B. (2000) Layers of time. A history of Ethiopia. London: C. Hurst \& Co.

Heywood, Linda (2000) Contested power in Angola, 1840 to the present. Rochester: University of Rochester Press/Woodbridge, Suffolk: Boydell \& Brewer.

Hitti, Philip K. (2002) History of the Arabs. From the earliest times to the present. London: Palgrave Macmillan. 10. ed.

Hochschild, Adam (1999) King Leopold's ghost. A story of greed, terror and heroism in colonial Africa. London: Macmillan. (Paperback London: Pan, 2002.) (Danish transl.: Kong Leopolds arv. København: Lindhardt og Ringhof, 2001. Norwegian transl.:Kong Leopolds arv. Oslo: Pax, 2002. Swedish transl.: Kung Leopolds vålnad. Stockholm: Ordfront, 2002.)

Holt, P.M. \& M. W. Daly (2000) A history of the Sudan. From the coming of Islam to the present day. London: Longman. 5. ed.

Hopkins, A.G. (1973) An economic history of West Africa. London: Longman. (New ed. announced.)

Horton, Mark \& John Middleton (2001) The Swahili. The social landscape of a mercantile society. Oxford: Blackwell.

Hourani, Albert (2002) A history of the Arab peoples. London: Faber and Faber. 2. ed. (Danish transl.: De arabiske folks historie. København: Gyldendal, 1998. Norwegian transl.: De arabiske folkenes historie. Oslo: Gyldendal, 2002. Swedish transl.: De arabiska folkens historia. Furulund: Alhambra, 1996.)

Hunt, Nancy Rose et al., eds (1997) Gendered colonialism in African history. Oxford: Blackwell.

Iliffe, John (1979) A modern history of Tanganyika. Cambridge: Cambridge University Press.

Iliffe, John (1987) The African poor. Cambridge: Cambridge University Press.

Iliffe, John (1995) Africans. The history of a continent. Cambridge: Cambridge University Press. (Swedish transl.: Afrika. Historien om en kontinent. Lund: Historiska media, 1997.)

Iliffe, John (2004) Honour in African history. Cambridge: Cambridge University Press.

Inikori, Joseph E. (2002) Africans and the industrial revolution in England. A study in international trade and economic development. Cambridge: Cambridge University Press.

Isaacman, Allen \& Richard Roberts (1995) Cotton, colonialism, and social history in sub-Saharan Africa. London: James Currey. 
Isichei, Elizabeth (1997) A history of African societies to 1870. Cambridge: Cambridge University Press.

Isichei, Elizabeth (2002) Voices of the poor in Africa. Rochester: University of Rochester Press.

Jackson, Tabitha (1999) The Boer war. London: Channel 4 Books.

Jankowski, James (2000) Egypt. A short history. Oxford: OneWorld.

Johnson, Douglas H. (2003) The root causes of Sudan's civil wars. Oxford: James Currey.

Johnson, R. W. (2004) South Africa. The first man, the last nation. London: Weidenfeld \& Nicolson.

Judd, Denis \& Keith Surridge (2002) The Boer war. London: John Murray. (Paperback 2003.)

July, Robert W. (1997) A history of the African people. Long Grove, Ill: Waveland. 5. ed.

Kalinga, Owen J. \& Cynthia A. Crosby (2001) Historical dictionary of Malawi. Lanham: Scarecrow Press. 3. ed.

Karis, Thomas G. \& Gail M. Gerhart, eds (1997) From protest to challenge. A documentary history of African politics in South Africa, 1882-1990, vol. 5: Nadir and resurgence, 1964-1979. Bloomington/Indianapolis: Indiana University Press.

Kershaw, Greet (1997) Mau Mau from below. Oxford: James Currey.

Kessel, Ineke van (2000)"Beyond our wildest dreams". The United Democratic Front and the transformation of South Africa. Charlottesville/London: University Press of Virginia.

Kimambo, Isaria N. (1991) Penetration \& protest in Tanzania. The impact of the world economy on the Pare 1860-1960. London: James Currey.

Kjekshus, Helge (1996) Ecology control and economic development in East African history London: James Currey. 2. ed.

Klein, Herbert S. (1999) The Atlantic slave trade. New York: Cambridge University Press.

Klein, Martin A. (1998) Slavery and colonial rule in French West Africa. New York: Cambridge University Press.

Koponen, Juhani (1994) Development for exploitation. German colonial policies in Mainland Tanzania, 1884-1914. Helsinki: Finnish Historical Society/Hamburg: Lit Verlag.

Law, Robin, ed. (1995) From slave trade to 'legitimate' commerce. The commercial transition in nineteenth-century West Africa. Cambridge: Cambridge University Press.

Lazreg, Marnia (1994) The eloquence of silence. Algerian women in question. London: Routledge.

Lewis, Ioan Myrddin (2002) A modern history of the Somali. Oxford: James Currey. 4. ed. 
Leys, Colin \& John S. Saul (1995) Namibia's liberation struggle. A two-edged sword. London: James Currey.

Leys, Colin \& Susan Brown (2005) Histories of Namibia. Living through the liberation struggle. London: Merlin Press.

Lipschutz, Mark R. \& R. Kent Rasmussen (1986) Dictionary of African historical biography. Berkeley: University of California Press. 2. ed.

Lobban, Richard A. et al. (2002) Historical dictionary of the Sudan. Lanham: Scarecrow Press. 3. ed.

Lovejoy, Paul E. (2000) Transformations in slavery. A history of slavery in Africa. Cambridge: Cambridge University Press. 2. ed.

Mackenzie, A. Fiona. D. (1998) Land, ecology and resistance in Kenya, 1880-1952. Edinburg: Edinburgh University Press.

MacQueen, Norrie (1997) The decolonization of Portuguese Africa. Metropolitian revolution and the dissolution of empire. London: Longman.

Maddox, Gergory et al. (1996) Custodians of the land. Ecology \& culture in the history of Tanzania. London: James Currey.

Maloba, Wunyabari O. (1993) Mau Mau and Kenya. An analysis of a peasant revolt. Bloomington: Indiana University Press. (Paperback 1998.)

Mandala, Elias C. (1990) Work and control in a peasant economy. A history of the lower Tchiri Valley in Malawi 1859-1960. Madison: University of Wisconsin Press.

Manning, Patrick (1990) Slavery and African life. Occidental, oriental and African slave trades. Cambridge: Cambridge University Press.

Manning, Patrick (1998) Francophone sub-Saharan Africa 1880-1995. Cambridge: Cambridge University Press. 2. ed.

Manning, Patrick (2004) Slavery, colonialism and economic growth in Dahomey, 1640-1960. Cambridge University Press. 2. ed.

Marcus, Harold G. (2002) A history of Ethiopia. Berkeley/Los Angeles: University of California Press. Rev. ed.

Marsot, Afaf Lutfi Al-Syyid (1985) A short history of modern Egypt. Cambridge: Cambridge University Press.

Maxon, Robert M. \& Thomas P. Ofcansky (2000) Historical dictionary of Kenya. Lanham: Scarecrow Press. 2. ed.

Maylam, Paul (2001) South Africa's racial past. The history and historiography of racism, segregation, and apartheid. Aldershot: Ashgate.

McCann, James (1999) Green land, brown land, black land. An environmental history of Africa, 1800-1990. Oxford: James Currey.

McEvedy, Colin (1995) The Penguin atlas of African history. London: Penguin. 2. ed.

McGrath, Simon et al., eds (1997) Rethinking African history. Edinburgh: Centre of African Studies, University of Edinburgh. 
Mendonsa, Eugene L. (2001) Continuity and change in a West African society. Globalization's impact on the Sisala of Ghana. Durham: Carolina Academic Press.

Mendonsa, Eugene L. (2002) West Africa. An introduction to its history, civilization and contemporary situation. Durham: Carolina Academic Press.

Meredith, Martin (2005). The state of Africa. A history of fifty years of independence. NewYork/London: The Free Press.

Mitchell, Peter (2005) African connections. Archeological perspectives on Africa and the wider world. Walnut Creek/Oxford: AltaMira Press.

Moore, Henrietta \& Megan Vaughan (1994) Cutting down trees. Gender, nutrition \& agricultural change in Northern Province of Zambia 1890-1990. London: James Currey.

Morgan Philip D. \& Sean Hawkins, eds (2004) Black experience and the empire. Oxford: Oxford University Press.

Morgenstierne, Christopher Munthe (2003) Denmark and national liberation in southern Africa. Uppsala: Nordiska Afrikainstitutet.

Nasson, Bill (1999) The South African war, 1899-1902. London: Edward Arnold.

Newitt, Malyn (1995) A history of Mozambique. London: C. Hurst \& Co.

Newman, James L. (1995) The peopling of Africa. A geographic interpretation. New Haven/London: Yale University Press.

Northrup, David (2002) Africa's discovery of Europe, 1450-1850. New York: Oxford University Press.

Nugent, Paul (2004) Africa since independence. London: Palgrave Macmillan.

Nzongola-Ntalaja, Georges (2002) The Congo from Leopold to Kabila. London: Zed Books.

Ochieng', W.R. \& R.M. Maxon, eds (1992) An economic history of Kenya. Nairobi: East African Educational Publishers.

Odhiambo, E.S. Atieno \& John Lonsdale, eds (2003) Mau Mau \& nationhood. Arms, authority \& narration. Oxford: James Currey.

Ogot, B.A. \& W. R. Ochieng, eds (1995) Decolonization \& independence in Kenya, 1940-93. London: James Currey.

Ogot, Berthwell A. (2002) The challenges of history and leadership in Africa. The essays of Bethwell Allan Ogot. Edited by T. Falola \& A. Odhlambo. Trenton: Africa World Press.

Ohaegbulam, Festus Ugboaja (2002) West African responses to European imperialism in the nineteenth and twentieth centuries. Lanham: University Press of America.

Oliver, Roland (1991) The African experience. London: Weidenfeld \& Nicholson. (Paperback London: Pimlico, 1993.) 
Oliver, Roland \& Anthony Atmore (2001) Medieval Africa, 1250-1800. Cambridge: Cambridge University Press. Rev. ed. (1. ed., 1981: The African middle ages 1400-1800.)

Oliver, Roland \& Anthony Atmore (2005) Africa since 1800. Cambridge: Cambridge University Press. 5. ed.

O'Meara, Dan (1996) Forty lost years. The apartheid state and the politics of the National Party, 1948-1994. Randburg: Ravan Press/Athens: Ohio University Press.

Omer-Cooper, J.D. (1994) A history of Southern Africa. Oxford: James Currey. 2. ed.

Otieno, Wambui Waiyaki \& Cora A. Presley (1998) Mau Mau's daughter. The life history of Wambui Waiyaki Otieno. Boulder/London: Lynne Rienner.

Owen, Roger (1993) The Middle East in the world economy 1800-1914. London: I. B. Tauris.

Owen, Roger \& Sevket Pamuk (1998) A history of Middle East economies in the 20th century. London: I.B. Tauris.

Oyebade, Adebayo, ed. (2003) The foundations of Nigeria. Essays in honor of Toyin Falola. Trenton: Africa World Press.

The Oxford history of the British Empire, vol. 1-6 (1998-1999) Oxford: Oxford University Press. (Paperback 2001.)

Oyewole, Anthony \& John Lucas (2000) Historical dictionary of Nigeria. Lanham: Scarecrow Press. 2. ed.

Pakenham, Thomas (1991) The scramble for Africa 1876-1912. London: Weidenfeld \& Nicholson. (Paperback London: Phoenix Press, 2001.)

Pankhurst, Richard (1998) The Ethiopians. Oxford: Blackwell. (Paperback 2000.)

Parsons, Neil ( 1993) A new history of southern Africa. London: Macmillan. 2. ed.

Pennell, C. R. (2003) Morocco. From empire to independence. London: C. Hurst \& Co.

Perkins, Kenneth J. (2004) A history of modern Tunisia. Cambridge: Cambridge University Press.

Phillips, Anne (1989) The enigma of colonialism. British policy in West Africa. London: James Currey.

Presley, Cora Ann (1992) Kikuyu women, the "Mau Mau” rebellion and social change in Kenya. Boulder/Oxford: Westview Press.

Prunier, Gérard (1998) The Rwanda crisis 1959-1994. History of a genocide. London: C. Hurst \& Co. 3. ed.

Ranger, Terence (1999) Voices from the rocks. Nature, culture \& history in the Matopos Hills of Zimbabwe. Oxford: James Currey.

Reader, John (1997) Africa. A biography of the continent. London: Hamish Hamilton. (Paperback London: Penguin, 1998.) 
Reynolds T. et al. (2004) Africa in world history. From prehistory to the present. Upper Saddle River: Pearson Education.

Roberts, Andrew, ed. (1990) The colonial moment in Africa. Essays on the movement of minds and materials, 1900-1940. Cambridge: Cambridge University Press.

Rodney, Walter (1972) How Europe underdeveloped Africa. London: BogleL'ouverture.

Rogerson, Barnaby (1998) A traveller's history of North Africa. New York: Interlink Books.

Ross, Robert (1999) A concise history of South Africa. Cambridge: Cambridge University Press. (Swedish transl.: Sydafrikas historia. Lund: Historiska media, 2001.)

Rubert, Stephen C. \& R. Kent Rasmussen (2001) Historical dictionary of Zimbabwe. Lanham: Scarecrow Press. 3. ed.

Saul, Mahir \& Patrick Royer (2001) West African challenge to empire. Culture and history in the Volta-Bani anticolonial war. Oxford: James Currey.

Saunders, Christopher \& Nicholas Southey (2000) Historical dictionary of South Africa. Lanham: Scarecrow Press. 2. ed.

Schmidt, Elizabeth (1992) Peasants, traders, and wives. Shona women in the history of Zimbabwe, 1870-1939. London: James Currey.

Seekings, Jeremy (2000) The UDF. A history of the United Democratic Front in South Africa 1983-1991. Oxford: James Currey.

Segal, Ronald (2002) Islam's black slaves. A history of Africa's other black diaspora. London: Atlantic Books. (Paperback 2003.)

Sellström, Tor, ed. (1999a) Liberation in southern Africa - regional and Swedish voices. Interviews from Angola, Mozambique, Namibia, South Africa, Zimbabwe, the frontline and Sweden. Uppsala: Nordiska Afrikainstitutet.

Sellström, Tor (1999b) Sweden and national liberation in southern Africa, vol. 1: Formation of a popular opinion 1950-1970. Uppsala: Nordiska Afrikainstitutet.

Sellström, Tor (2002) Sweden and national liberation in southern Africa, vol. 2: Solidarity and assistance 1970-1994. Uppsala: Nordiska Afrikainstitutet.

Sheldon, Kathleen E. (2002) Pounders of grain. A history of women, work, and politics in Mozambique. Portsmouth: Heinemann.

Sheriff, Abdul \& Ed Ferguson, eds (1991) Zanzibar under colonial rule. London: James Currey.

Sherwood, Marika \& Hakim Adi (2003) Pan-African history. Political figures from Africa and the diaspora since 1787. London: Routledge.

Shillington, Kevin (1995) History of Africa. Oxford: Macmillan Education. 2. ed. (New ed. announced.)

Simensen, Jarle (2004) Afrikas historie. Oslo: Cappelen Akademisk Forlag. 4. ed. 
Soiri, Iina \& Pekka Peltola (1999) Finland and national liberation in southern Africa. Uppsala: Nordiska Afrikainstitutet.

Stora, Benjamin (2001) Algeria 1830-2000. A short history. Ithaca/London: Cornell University Press.

Terreblanche, Sampie (2003) A history of inequality in South Africa 1652-2002. Pietermaritzburg: University of Natal Press.

Thompson, Leonard (2001) A history of South Africa. New Haven/London: Yale University Press. 3. ed.

Thornton, John (1998) Africa and Africans in the making of the Atlantic world 1400-1800 Cambridge: Cambridge University Press. 2. ed.

Thornton, John (1999) Warfare in Atlantic Africa, 1500-1800. London: UCL Press.

Throup, David (1988) Economic and social origins of Mau Mau, 1945-53. London: James Currey.

Tvedt, Terje (2004) The river Nile in the age of the British. London: I.B. Tauris.

UNESCO (1981-1993) A general history of Africa, vol. 1-8. London: Heinemann. (Paperback Oxford: James Currey, 1990-1999.)

Van Onselen, Charles (1996) The seed is mine. The life of Kas Maine, a South African sharecropper 1894-1985. London: James Currey.

Vandervort, Bruce (1998) Wars of imperial conquest in Africa 1830-1914. London: UCL Press.

Vaughan, Megan (1987) The story of an African famine. Gender and famine in twentieth-century Malawi. Cambridge: Cambridge University Press.

Walvin, James (1998) An African life. The life and times of Olaudah Equiano, 17451979. London/New York: Continuum Books.

Watterson, Barbara (1997) The Egyptians. Oxford: Blackwell. (Paperback 1998.)

Wesseling, H.L. (1996) Divide and rule. The partition of Africa, 1880-1914. Westport, Connecticut/London: Praeger Publishers.

Wesseling, H.L. (2004) The European colonial empires 1815-1919. Harlow: Pearson Longman.

Wilson, H.S. (1994) African decolonization. London: Edward Arnold.

Winks, Robin W., ed. (1999) Historiography. Oxford: Oxford University Press. (The Oxford history of the British Empire, 5.)

Worden, Nigel (2000) The making of modern South Africa. Oxford: Blackwell. 3. ed.

Worger, William H. et al., eds (2001) Africa and the West. A documentary history from the slave trade to independence. Phoenix: Oryx Press.

Wright, Donald R. (2004) The world and a very small place in Africa. A history of globalization in Niumi, the Gambia. Armonk, New York/ London: M.E. Sharpe.

Wright, Marcia (1993) Strategies of slaves \& women. Life-stories from East/Central Africa. London: James Currey. 
Young, Crawford (1994) The African colonial state in comparative perspective. New Haven/London: Yale University Press.

Zeleza, Paul Tiyambe (1993) A modern economic history of Africa, vol. 1: The nineteenth century. Dakar: CODESRIA.

Zeleza, Paul Tiyambe \& Dickson Eyoh, eds (2003) Encyclopedia of twentiethcentury African history. London: Routledge.

Zewde, Bahru (2001) A history of modern Ethiopia 1885-1991. Oxford: James Currey. 2. ed. 


\title{
Politics and economy
}

\author{
Tore Linné Eriksen
}

\section{General overviews}

A good point of departure for those wishing to gain a broad overview of contemporary society in Africa is Understanding contemporary Africa (Gordon \& Gordon 2001), which devotes separate chapters to a range of themes including economy, politics, the environment, and the situation for women. Contemporary Africa (Falola 2003) is the final volume of a fivevolume work on African history (see the 'History' chapter of this publication), and comprises thirty-eight thematically organised chapters (politics, administration, culture, population, environment, economy etc.) as well as articles devoted to each of the five main regions of Africa.

A political science introduction to the study of African politics which is well suited for teaching purposes, is Politics and society in contemporary Africa edited by Naomi Chazan et al. (1999). A short, well-written and up to date introduction is provided in An introduction to African politics, written by the British political scientist Alex Thomson (2004). Further recommended overviews are William Tordoff's Government and politics in Africa (2002), and Peter J. Schraeder's African politics and society (2004).

Among the available books that provide a comprehensive and up to date perspective and which do not require prior knowledge of the subject, there is special reason to recommend African renaissance (Cheru 2002), Issues in the contemporary politics of sub-Saharan Africa (Harrison 2002) and Closing the circle (Sandbrook 2000). Two other prominent scholars who have collected their respective articles in book form are Colin Leys (1996) and John S. Saul (2001). Colin Legum (1999) concisely examines a number of key trends in Africa since independence. Journalistic portraits of the African continent are rendered by Mark Huband (2001) and by Howard W. French (2004), while Peter Schwab (2001) and George B.N. Ayittey (2005) chiefly concern themselves with negative development trends. The relationship between politics, religion, and religious movements is explored by Jeff Haynes (1996). The connection between economic decline and political crisis is thoroughly examined by Nicolas van de Walle in African economies and the politics of permanent crisis, 1979-1999 (2001). Eastern and southern Africa (Potts \& Bowyer-Bower 2003) is an up to date exposition of politics, economy and ecology, which discusses development trends with relevance for the entire continent.

Several books mentioned in the 'History'chapter of this publication contain a wealth of information on recent political and economic developments, such as Cooper (2002), Nugent (2004) and Meredith (2005). There is no lack of useful readers concerned with contemporary African 
society. Two recent anthologies on African politics are Readings in African politics (Young 2003) and The politics of transition in Africa (Mohan \& Zack-Williams 2004). A wealth of material is also to be found in Africa in crisis: New challenges and possibilities (Zach-Williams et al. 2002), Class, struggle and resistance in Africa (Zeilig 2002), Contending issues in African development (Iheduru 2001) and The African state (Samatar \& Samatar 2002). A good deal of interesting material is still to be found in anthologies edited by Chabal (1986); Ellis (1996); Glickman (1995); Himmelstrand (1994); Joseph (1999); Lewis (1998); Martin \& O’Meara (1995); NzongolaNtalaja \& Lee (1998); Negash \& Rudebeck (1995); Olukoshi \& Laakso (1996); Olukoshi \& Wohlgemuth (1995); Ottaway (1997); Villalón \& Huxtable (1998) and Zartman (1995).

Many individual studies have been published that provide in-depth analyses of specialised themes, such as the nature and distinctive features of the African state and political systems in Africa. These studies usually require greater levels of prior knowledge than is the case for most of the above mentioned overview literature. Three key books that have attained considerable importance within academia, and which have spawned a number of exciting and critical debates, are The state in Africa: The politics of the belly (Bayart 1993), Citizen and subject: Contemporary Africa and the legacy of late colonialism (Mamdani 1996) and The criminalization of the state in Africa (Bayart et al. 1999). Other authors who have written books in this category are Baker (2000); Boone (2003); Chabal (1992); Chabal \& Daloz (1999); Herbst (2000); Reno (1998); Schatzberg (2001) and Tangri (1999).

The problematic situation encompassing ethnic conflict, national identity and democracy is examined by the Kenyan scholar and political activist Koigi wa Wamwere in Negative ethnicity (2003). The most recent anthology that provides a thematic overview is Ethnicity \& democracy in Africa (Berman et al. 2004). There are also a number of other anthologies concerned with the same issues, such as Ethnicity kills (Braathen 2000), Ethnic conflicts in Africa (Nnoli 1998) and National identity and democracy in Africa (Palmberg 1999). African guerrillas (Clapham 1998) examines guerrilla movements within African countries following the colonial era, while $M e$ against my brother is a more journalistic presentation of conflict in Rwanda, Sudan and Somalia (Petterson 2000). Other central themes are approached in The military and militarism in Africa (Hutchful \& Bathily 1998) and Peasant organizations and the democratic process in Africa (Romdane \& Moyo 2002). Questions relating to democracy and the media are examined in Media and democracy in Africa (Hydén 2002) and Media i Afrika: Afrika i media (Fellesrådet for Afrika 2002). Views held by the younger generation concerning the future prospects of the African continent are recounted in African voices African visions (Adesida \& Oteh 2001).

Concerning literature on African politics published in Nordic languages, there is good reason to recommend Afrikanere om Afrika (Fellesrådet for Afrika 2000). This is an anthology of selected articles written by prominent African social scientists such as Samir Amin, Thandika Mkandawire, 
Mahmood Mamdani and Ifi Amadiume, and also includes profiles of all African countries. A more journalistic account is given in Mor Afrika (Kristiansen 1994). In Norwegian there is also Afrika: Natur, samfunn og bistand (Stenseth et al. 1995), which thematically covers a wide terrain. Two Danish books that provide a wealth of useful information for beginners, despite being over a decade old, are Afrika det ukuelige kontinent (Rye-Olsen 1994) and Det sorte Afrika mellan håb og desperation (Vilby 1994). Afrika (Palmberg 1994) is a proficient textbook in the Swedish language with an emphasis on contemporary African society. The Swedish journalist and author Anders Ehnmark has written two short and thought-provoking books, Resan till Kilimanjaro (1993) and Resa i skuggan (1995).

\section{Political parties and democratisation}

A wealth of literature has been published in recent years on matters pertaining to civil society, democratisation, political parties and forms of governance in Africa. This body of work includes many important contributions by western and African social scientists alike. Concerning the latter, two books by Claude Ake are recommended: Democracy and development (1996) and The feasibility of democracy in Africa (2000). A further recommended publication is African democracies \& African politics (Salih 2001). Article anthologies that are chiefly authored by African scholars include: Civil Society and democracy in Africa (Kasfir 1998); African studies in social movements and democracy (Mamdani \& Wamba-dia-Wamba 1995); The transition to democratic governance in Africa (Mbaku \& Ihonvbere 2003); Discourses on democracy (Nyang'oro 1996) and The politics of opposition in contemporary Africa (Olukoshi 1998). A very well structured review of contributions to the democracy debate by African social scientists is a political science thesis entitled Fri til å velge? (Reigstad 2002).

Among the wealth of detailed studies on the possibilities (and barriers) for democracy in Africa, Democratic experiments in Africa (Bratton \& van de Walle 1997) and Disciplining democracy (Abrahamsen 2000) are particularly worthy of note. Among the most widely read anthologies on democratisation are Diamond \& Plattner (1999), Melin (1995), NzongolaNtalaja \& Lee (1998), Widner (1994) and Wiseman (1995). More specifically concerning political parties, a recommended new anthology of case studies is African political parties (Salih 2003). Other useful anthologies that focus on political parties and elections are Multi-party elections in Africa (Cowen \& Laakso 2002) and Voting for democracy (Daniel 1999). 


\section{Africa in the international system}

Africa in international politics, including the foreign policies of African states, is an area of study of its own and is studied primarily by political scientists. There is an excellent introduction to this field in Norwegian entitled Internasjonal politikk og utenrikspolitikk i Afrika sør for Sahara, written by Morten Bøås and Karin Dokken (2002). Among the most widely used textbooks are Africa in international politics (Taylor \& Williams 2004) and Africa and the North (Engel \& Rye Olsen 2005). Two further recommended overviews are Africa in world politics (Harbeson \& Rotchild 2000) and Africa in the international system (Clapham 1996). A large collection of recently written articles concerning 'the age of globalization', most of them by African scholars, have been collected in Globalizing Africa (Smith 2003). A number of chapters relating to the ongoing debate on Africa's place in globalization are also to be found in Paul T. Zeleza's Rethinking Africa's globalization (2003). While East Africa is the primary focus of attention in The international politics in East Africa (Pinkney 2001), this book also provides a more general overview of how international organisations and international agreements influence African politics. Among the slightly older anthologies that contain still relevant material are African foreign policies (Wright 1999) and Globalization, human security, and the African experience (Thomas \& Wilkin 1999). Overviews of Africa's relations with the European Union are provided in The European Union and Africa (Brown 2002) and The European Union and the Third World (Holland 2002). Intervention by African states into neighbouring countries is the theme of a collection of case studies entitled African interventionist states (Furley 2001), while the consequences of international 'humanitary intervention' in Africa is examined in Eroding local capacity: International humanitarian action in Africa (Juma \& Suhrke 2002). A large number of studies have been published on processes of transition from conflict to reconstruction, the best anthologies in this field are From conflict to reconstruction in Africa (Addison 2003) and Out of conflict (Sørbo \& Vale 1997).

The central literature addressing conflicts between African states will be introduced in the regional section of this chapter (see below). In the section concerning economic conditions, I introduce the large body of literature that provides better understanding of Africa's place in the global community, not the least important here being themes relating to the World Bank, the International Monetary Fund (IMF) and international trade.

\section{Gender issues and the conditions of women}

A number of noteworthy books have recently been published that examine the situation of women in African politics and social life. This is the central 
theme in Mødrenes kontinent by Torild Skard (2001), in which the author provides an engaging narrative based on her experience as Regional Director for UNICEF in West Africa and Central Africa (the book is also available in an English edition). The most recent anthology is edited by Andrea Cornwall: Readings in gender in Africa (2005). Two important monographs are April A. Gordon's Transforming capitalism and patriarchy: Gender and development in Africa (1996), and December Green's Gender violence in Africa (1999). Women's participation in political decision making, organisations and institutions is exhaustively examined in a number of studies that are either written or edited by Aili Mari Tripp, and who bases most of her analyses on material from Uganda (Tripp 2000, Tripp \& Kwesiga 2002). A number of good contributions in this field of study, with an emphasis on studies carried out in Uganda and South Africa, have been collected in No shortcuts to power: African women in politics and policymaking (Goetz and Hassim 2003). Among other available collections of articles, those worthy of particular mention are: African women south of the Sahara (Hay \& Stichter 1995); African feminism (Mikell 1997); What women do in wartime (Turshen \& Twagiramariya 1998); Gender, work and population in sub-Saharan Africa (Adepoju \& Oppong 1994) and Women and the state in Africa (Parpart \& Staud 1989). The role of women during the liberation struggle and since independence is examined in detail by Gisela Geisler in Women and the remaking of politics in southern Africa (2004).

\section{Economy, development co-operation, and structural adjustment}

Many of the above mentioned overviews also include contributions that illuminate key economic trends and challenges in Africa. Current perspectives and a wealth of useful data are to be found in a series of reports published by the United Nations Conference for Trade and Development (UNCTAD): Economic development in Africa. From adjustment to poverty reduction (2002); Economic development in Africa. Trade performance and commodity dependence (2004) and Economic development in Africa. Debt sustainability. Oasis or mirage? (2004). A further study carried out by UNCTAD, which is particularly useful for the linkages that it makes to other regions of the world, is African development in a comparative perspective (1999). The African Development Bank publishes annual reports containing a wealth of informative and thematic material. The two latest reports concern globalization and African development (2003) and Africa's position in the global trading system (2004). Two comprehensive and very informative collections of articles are Renewing development in sub-Saharan Africa (Belshaw \& Livingstone 2002) and From crisis to growth in Africa (Lundahl 2001). Issues concerning agriculture and food security are of fundamental importance in African countries, and a good introduction to this theme is 
provided in the anthology entitled Food security in sub-Saharan Africa (Devereux \& Maxwell 2001). Africa's position in world trade is topically presented and discussed in the anthology entitled For en neve dollar. Handel med Afrikas framtid (Fellesrådet for Afrika 2003). Africa in the global economy (Mshomba 2000) is not as encompassing as the title promises, but nonetheless provides a lucid commentary on the situation of Africa in the world trade system at the end of the 1990s. Because most of the countries that are included in the United Nations category of 'least developed countries' are in Africa, a highly recommended publication is De minst utvecklade länderna och världshandeln (De Vylder 2001). Many influential studies on Africa have been conducted by the World Bank. Two of the most recent are Can Africa claim the 21st century? (World Bank 2000) and African poverty at the millennium (White 2001).

New Partnership for Africa's Development (NEPAD) is an initiative taken by African leaders to promote economic development and democracy. Two books that critically discuss this initiative, and which refer to relevant documentation, are NEPAD: A new path? (Nyong'o 2002) and Fanon's warning: A civil society reader on the New Partnership for Africa's Development (Bond 2002). Many useful contributions have also been collected in The New Partnership for Africa's Development (Hayman 2003).

Structural adjustment and neo-liberalism

A central theme in both academic and political debate has been the programme for economic re-orientation towards a neo-liberal market economy. This programme, which is more usually known as structural adjustment', has, under the direction of the World Bank and western aid donors, been dominant in Africa since the mid-1980s. Accordingly, a large amount of the literature concerning African economies and their prospects for development are closely linked to this discussion. Perhaps not unexpectedly, the World Bank has, in a large number of publications, presented positive appraisals of both the goals and the results of this programme. The most important publications here are Adjustment in Africa (World Bank 1994), Adjustment in Africa: Lessons from case studies (Husain \& Faruquee 1996), Aid and reform in Africa (Dollar 2001) and Aid and reform in Africa: Lessons from ten case studies (Deverajan 2001). For a more critical evaluation, a good point of departure is the well-written overview entitled Our continent, our future: African perspectives on structural adjustment (Mkandawire \& Soludo 1999). The basis of this book is a comprehensive research programme directed by the Council for the Development of Social Science Research in Africa (CODESRIA). A wide range of background papers are published in African voices on structural adjustment (Mkandawire \& Soludo 2003). Many overviews and individual studies have been published in a number of anthologies, the most widely used being: Labour regimes and liberalisation (Beckman \& Sachikonye 2001); Structural adjustment (Mohan 2000); Limits to adjustment in Africa (Engberg-Pedersen 1996); Structural adjustment and 
beyond (Hoeven \& van der Kraaij 1994); Structurally adjusted Africa (Simon 1995); Between liberalisation and oppression (Mkandawire \& Olukoshi 1995); Beyond economic liberalization in Africa (Mengisteab \& Logan 1995) and Social change and economic reform in Africa (Gibbon 1993). Two individual monographs that can still be profitably read are Africa's choices (Barrett Brown 1995) and A blighted harvest (Gibbon et al. 1993). Written with a braoder audience in mind Anpassas eller utvecklas (Hermele 1996) is addressing topical issues such as structural adjustment, debt and aid. Structural adjustment is approached from a critical NGO-perspective in Structural adjustment: The SAPRIN report (SAPRIN 2004), while a large number of country studies examine the consequences of poverty reduction strategies (PRS) in Fighting poverty in Africa (Booth 2003).

\section{Development co-operation}

Aid and development co-operation are themes the are tightly interwoven in the literature concerning the World Bank and structural adjustment. A book that provides an introduction to this important issue is Aid to Africa (Lancaster 1999). Many anthologies published by the Nordic Africa Institute focus on the same discussion, see for example, Jerker Carlsson (1997), Kjell Havnevik \& Brian van Arkadie (1996) and Steve Kayizzi-Mugerwa (1998). Alex de Waal focuses on aid and relief assistance during crises in his book entitled Famine crimes (1997).

\section{Regional and country studies}

A large amount of the above mentioned literature includes specific chapters and articles devoted to case studies on individual countries. These often take the form of concise overviews that aim at readers seeking introductions to specific countries or themes. Many of the books that are introduced in the 'History' chapter of this publication follow various issues up to the present day. This makes any clear demarcation between literature on 'history' and 'politics and economy' problematic. Recently published books that are illustrative of this situation include books on the Sudan (Johnson 2003), Congo (Nzongola-Ntalaja 2002), Egypt (Goldschmidt 2003) and South Africa (Clark \& Worger 2003). Those readers seeking more detailed knowledge about specific countries should carry out their own library, bibliography and data base searches. Academic journals and periodicals are also invaluable sources in this regard. The following discussion therefore introduces only a selection of the available literature, and aims to provide a condensed introduction with an emphasis on the larger countries of the continent (South Africa, Nigeria, Egypt) and areas currently affected by

conflict. The book series entitled Nations of the contemporary world (Westview Press) includes a range a books that provide useful introductions 
to African countries, including for example Angola (Tvedten 1997), Uganda (Ofcansky 1999) and Nigeria (Wright 1998). In the Danish language, a large selection of reports (free of charge) are available under the umbrella title En politisk og økonomisk oversigt, published by Danida/Udenrigsministeriet. Among the most recent reports, are those on Benin (Breinholt 2001), Malawi (Larney 2001) and Eritrea (Nielsen 2000).

\section{Southern Africa}

For literature concerning the southern African region as a whole, a good place to start is Det sydlige Afrika i kort og tal, written by Knud Vilby (1997). An up to date and highly informative presentation is given in Politics in southern Africa (Bauer \& Taylor 2005). South Africa's foreign policy and the country's dominant role in the region are themes that are approached in South Africa in southern Africa (Simon 1998). An exciting study with a regional perspective and a particular emphasis on economy and politics, is Economic change, governance and natural resource wealth (Reed 2001). A topical discussion of regional co-operation is Margaret C. Lee's The political economy of regionalism in southern Africa (2003). Limits to liberation in Southern Africa (Melber 2003b) is a collection of articles that critically discusses the difficulties involved in achieving democratic development since independence.

South Africa is not unexpectedly the country with the richest sources of literature. For many readers, the first introduction to South Africa will be Mandela's autobiography entitled Long walk to freedom (1994), which has subsequently been translated into a large number of languages. Martin Meredith (1997) and Anthony Sampson (1999) have also written comprehensive biographies of Nelson Mandela. A biography in the Norwegian language is Nelson Mandela: Ett liv i Kamp mot rasisme og undertrykking, which is written primarily for younger readers (Eriksen 2002). In his own words (Mandela 2003) is a collection of speeches made by Mandela during the course of the last decade. A detailed and stimulating meeting with two other anti-apartheid leaders is provided in Walter and Albertina Sisulu: In our lifetime (Sisulu 2003), while the most nuanced presentation of Winnie Mandela is Winnie Mandela: A life (Bezdrob 2003). The history of Chris Hani's life is told in Chris Hani. Portrait of a South African revolutionary (Suttner 2003).

The critical years of transition from apartheid to democracy are described in a discerning and lucid manner by the South African journalist Allister Sparks in Tomorrow is another country (1995). He has also written Beyond the miracle (2003) which is a follow-up of subsequent developments. Journalistic accounts in Nordic languages include, among others, I Mandelas land (Kristiansen 1995), I Sydafrika (Wästberg 1995) and 'Undskyld, hvor er den hvide kø?’ (Strudsholm \& Holsting 1994), while Sydafrika: En regnbågsnation föds (Palmberg \& Strand 1995) provides a more academic 
presentation. This era is also recounted in a collection of articles by Desmond Tutu entitled The rainbow people of God (1994).

Studies on political developments in South Africa over the past decade provide a wealth of literature from which to choose. For a concise introduction, a good place to start is Anthony Butler's Contemporary South Africa (2004). An up to date exposition of the political system, written by a prominent South African social scientist, is Politics in South Africa: From Mandela to Mbeki (Lodge 2003). Two other studies in the same category are Politics and society in South Africa (Glaser 2001) and The politics of a new South Africa (Deegan 2001). Elite transition (Bond 2000), Against global apartheid (Bond 2003) and South Africa: Limits to change (Marais 2001) are all authored by scholars who adopt a critical stance to contemporary politics, which they see as a departure from the radical ideas that prevailed during the anti-apartheid struggle. An exciting discussion of the political course taken over the past few years is provided in Thabo Mbeki's world (Jacobs \& Calland 2003). The importance of continuing the struggle for social justice is the central theme in Unsustainable South Africa (Bond 2002), We are the poors (Desai 2002) and Talk left, walk right (Bond 2004).

The work carried out by the South African Truth and Reconciliation Commission provides the backdrop for a large number of books concerning fundamental questions about reconciliation, guilt, responsability, compensation, and justice. Desmond Tutu relates his own account of the Commission's work in No future without forgiveness (1999). The most recently published studies in this area are Unfinished business: South Africa, apartheid and truth (Bell \& Ntsebeza 2003) and Bearing witness (Ross 2003). Among other books concerning the same theme, recommended examples are Country of my scull (Krog 1998), Truth and reconciliation in South Africa (Graybill 2002), Coming to terms (Meredith 1999) and The South African Truth Commission (Christie 2000). Three South African anthologies that provide a multifaceted account of both the work and the significance of the Commission are Commissioning the past (Posel \& Simpson 2002), Looking back, reaching forward (Villa-Vicencio \& Verwoerd 2000) and Reconciliation through truth (Asmal 1997).

Zimbabwe is another country that has attracted the interest of many researchers and journalists. Topical books that focus on Robert Mugabe's dictatorial rule are Robert Mugabe: A life of power and violence (Chan 2003), Twenty years of independence in Zimbabwe (Darnolf \& Laakso 2003) and Mugabe: Power and plunder in Zimbabwe (Meredith 2002). A large number of books situate the abuse of power, conflict and growing social inequalities in the context of the shift toward a more neo-liberal market economy. Such a perspective characterises, among others, recent books by Patrick Bond \& Masimba Manyana (2002), Horace Campbell (2003), Hevina Dashwood (2000) and John L. Moore (2003). For detailed studies on land ownership and land reforms, see Sam Moyo's The land question in Zimbabwe (1995) and Land reform under structural adjustment (2000). The role of trade unions in 
the context of Zimbabwean politics since independence is dealt with in Striking back (Raftopolous \& Sachikonye 2001).

Two insightful books on Mozambique from the mid-1990s are Mozambique: The troubled transition (Abrahamsson \& Nilsson 1995) and Confronting Leviathan (Hall \& Young 1997). Recent overviews that more specifically focus on the peace process, reconstruction and the market economy are Mozambique and the construction of the new African state (Alden 2001) and Transforming Mozambique (Pitcher 2002). The British journalist Joseph Hanlon has authored a large number of important books about Mozambique, the two most recent being Peace without profit (1996) and Mozambique \& the great flood (Christie \& Hanlon 2001). A good introduction to Angola is Angola: Struggle for peace and reconstruction (Tvedten 1997). A well-written study that specifically explores the significance of the role of oil in terms of the incidence of war, plundering and corruption, is Angola: Anatomy of an oil state (Hodges 2004). The first decade of Namibia's independence (1990-2000) is examined in a number of anthologies, among the best being Contemporary Namibia (Diener \& Grafe 2001), Namibia: A decade of independence (Melber 2000) and Re-examining liberation in Namibia (Melber 2003a). An informative book on women's lives is Kvinnor i Namibia (Jönsson \& Laskar 2000). Concerning Malawi, a short introduction is available in Danish (Larney 2001), and an excellent anthology of articles is edited by Harri Englund (2002). A good study of Botswana's political and economic development that explains how democracy and growth are inter-related, is An African miracle (Samatar 1999). A topical study of economy and politics in Zambia is Political and economic liberalisation in Zambia 1991-2001, written by the Norwegian social scientist Lise Rakner (2003). Other books that have examined this theme are Economic crisis, civil society \& democratization (Ihonvbere 1996) and Democracy in Zambia (Sichone \& Chikulo 1996), while Aid and poverty reduction in Zambia (Saasa \& Carlsson 2002) cast critical light on the aid sector.

\section{East Africa, Central Africa and the Horn of Africa.}

East Africa's position in the international political arena is, as has been mentioned above, exhaustively presented by Robert Pinkney (2001). Although they do not include the latest developments, there is still much to be gained from two classical works: Tanzania: The limits to development from above (Havnevik 1993) and Beyond capitalism vs. socialism in Kenya \& Tanzania (Barkan 1994). The important role played by Julius Nyerere in Tanzanian and in African politics more widely, is informatively discussed in two anthologies respectively edited by Colin Legum \& Geoffrey Mmari (1995) and David McDonald \& E.N. Sahle (2002). A critical appraisal of the role of donor assistance is provided in Lethal aid: The illusions of socialism and self-reliance in Tanzania (Rugumamu 1997). A book which at least partially balances what is an otherwise overtly pessimistic body of literature, 
is a penetrating analysis of a Tanzanian local community, which among other issues emphasises the community's capacity to survive and engender development, is Ecology, civil society and the informal economy in North West Tanzania (Smith 2001). In two books Kogi wa Wamwere combines autobiographical reflections with a critical outlook on Kenyan politics (1995, 2002).

Uganda's development is examined in a number of anthologies edited by Holger Bernt Hansen \& Michael Twaddle, the most recently published being Developing Uganda (1998). For a concise introduction to the series of country studies by Danida, see Knud Vilby (1998). As is related in the foregoing discussion, many studies have focused on mobilisation among women and women's role in Ugandan politics (Tripp 2000, Tripp \& Kwesiga 2002, Goetz \& Hassim 2003).

The conflict in Congo is examined in a highly perceptive study by Gérard Prunier in From genocide to continental war (2002). A well-written narrative is presented by the Danish journalist Peter Tygesen in Congo formoder jeg (2002). As is mentioned in the 'History'chapter of this publication, more recent events in the Congo are covered in detail by Georges Nzongola-Ntalaja (2002). Journalistic and insightful commentaries on Rwanda are provided by, for example, Philip Gourevitch (1999), Fergal Keane (1996) and Scott Peterson (2000). In addition to Gérard Prunier's study (see the 'History' chapter of this publication), the standard academic work on Rwanda is When victims become killers (Mamdani 2001). An anthropological perspective on the conflict is presented by Johan Pottier (2002). International aspects are at centre stage in a detailed collection of articles edited by Howard Adelman \& Astri Suhrke (1999), while the complicity of western countries is clearly illustrated in A people betrayed (Melvern 2000) and Conspiracy to murder (Melvern 2004).

The recently published new edition of Peter Woodward's classic work The Horn of Africa (2002) serves as an excellent introduction to a region deeply affected by conflict. Also published in a new edition is John Drysdale's Whatever happened to Somalia? (2001). In Resource conflict in the Horn of Africa, John Markakis (1998) looks more closely at fundamental conflicts over resources, while Islamism and its enemies in the Horn of Africa (de Waal 2004) is a collection of topical writings concerning the social and political manifestations of Islamism in a conflict-torn region. For those wishing to gain an insight into the tragic oppositions between Ethiopia and Eritrea, an invaluable book is Brothers at war (Negash \& Tronvoll 2000). Søren Walter Nielsen (2000) provides a brief introduction to Eritrea in the Danish language. Two topical and thorough anthologies concerning Ethiopia are Ethiopia since the DERG (Pausewang 2002) and Ethiopia: The challenge of democracy from below (Zewde \& Pausewang 2002). 


\section{West Africa}

The best point of departure for those seeking a better understanding of Nigeria, one of Africa's most influential countries, is This house has fallen: Nigeria in crisis (Maier 2000). A comprehensive introduction is also provided by Stephen Wright in Nigeria: Struggle for stability and status (1998). Also covering the same era, i.e. prior to the fall of the military dictatorship, is The crippled giant. Nigeria since independence (Osaghe 1998), as does Illusion of power: Nigeria in transition (Ihonvbere \& Shaw 1998). Ken Saro-Wiwa, the Nigerian author and human rights activist who was hanged by the military regime in 1995, provides an autobiographical account of the Ogoni people's struggle against the Shell oil company and the Nigerian dictatorship in A month and a day: A detention diary (1995). This struggle is also lucidly recounted and analysed in Where vultures feast: Shell, human rights and oil (Okonta \& Douglas 2003). A case study of the role played by the trade union movement during economic structural adjustment is provided in The Nigerian textile industry (Andrae \& Beckman 1998).

Topical analyses of states experiencing conflict and disintegration include The mask of anarchy. The destruction of Liberia and the religious dimension of an African civil war (Ellis 1999), Sierra Leone: Diamonds and the struggle for democracy (Hirsch 2001) and Somalia: Economy without state (Little 2003). Ghana is the focus of analysis in a brief overview published by Danida (Jespersen 1998) and in two thorough studies on the consequences of structural adjustment and economic reorientation to market liberalism: Ghana's adjustment experience (Hutchful 2002) and IMF AND World Bank sponsored structural adjustment programs in Africa (KonaduAgyemang 2001). An excellent analysis of the preconditions for, and the reality of democracy in Guinea-Bissau, is provided in Lars Rudebeck's On democracy's sustainability (2001). The majority of the more recent publications concerning the former French colonies in West Africa are naturally written in French, and are therefore not included in this review. By far the best overviews in English are Patrick Manning's Francophone subSaharan Africa 1880-1995 (see the 'History' chapter of this publication), and Victor T. Le Vine's Politics in Francophone Africa (2004). Introductions to three West African countries are included in Danida's series of handbooks, these are Benin (Breinholt 2000), Niger (Lund 1997) and Burkina Faso (Lund \& Marcussen 1996). Vivi-Ann Sjögren relates her impressions gained from her travels in Benin in Anteckningar från Benin (2001).

\section{The Middle East and North Africa}

The standard work on the politics of both the Middle East and North Africa, and which include both articles and studies on specific countries, is The government and politics of the Middle East and North Africa (Long and Reich 2002). A new overview work with the same focus is The politics of the Middle East and North Africa (Sorensen 2005). An analytical overview (but 
without chapters on specific countries) written by Roger J. Owen is entitled State, power and policy-making in the making of modern Middle East (2004). Two further popular textbooks are Contemporary politics in the Middle East (Milton-Edwards 2000) and Understanding the contemporary Middle East (Gerner \& Schwedler 2004). Nation, society and culture in North Africa (McDougall 2003) and North Africa in transition (Zoubir 1999) are two useful anthologies, while States and women's rights (Charrad 2001) is a penetrating study that discloses important disparities between women's social positions in Morocco, Tunisia and Algeria. In Dangerous alliances, Lise Garon (2003) discusses the potential for democratization in North Africa, with particular emphasis on the role of the media. (In a similar manner to the case of Francophone West Africa, much of the good academic literature on North Africa is in French).

As is discussed in the 'History' chapter in this publication, the key aspects in the development of Egypt have been brought up to the present day in Arthur Goldschmidt's standard work on Egypt. A contemporary analyses of the political system is presented in The politics of Egypt (Fahmy 2002). The economic crisis and the politics of reform (Bush 1999) is a thorough study of political and economic transition following structural adjustment during the 1990s, and particularly emphasises rural change. The same theme is the object of study in two valuable anthologies edited by Ray Bush (2002) and Nicholas Hopkins \& Kirsten Westergaard (1998), while industry and structural adjustment are the themes approached in Stabilization and adjustment in Egypt (Abdel-Khalek 2001). The rise of what is commonly called Islamism or Islamic 'fundamentalism' is discussed in Barry Rubin's Islamic fundamentalism in Egypt (2002), which has been periodically updated in new editions.

Developments in Algeria over the last number of years, especially the advance of Islamism, are concisely presented by Inga Brandell in Algeria: Demokratins och islamismens tid (1998). An informative narrative that is related in a more journalistic prose is Cathrine Løchstøers Algerie: Ved demokratiets grense (1995). Two detailed academic studies concerning the same theme are Battlefield Algeria (Roberts 2003) and Islam and democracy (Volpi 2002). An up to date and collected overview of economy and politics in Morocco is provided in both Morocco: Transformations and continuity (Gould 2002) and Morocco under King Hassan (Hughes 2001). A good introduction to Libya is Libya since independence (Vandewalle 1998). Tensions between economic liberalisation and political democratization in Tunisia are examined in Liberalization against democracy (King 2003). Douglas O. Johnson's standard textbook on the history of modern Sudan follows developments up to the present day (see the 'History' chapter in this publication), while the peace process initiated several years ago, and the role played by civil society in the process of democratization is discussed in The Phoenix state (Salam \& de Waal 2001). 


\section{References}

Abdel-Khalek, Gouda (2001) Stabilization and adjustment in Egypt. Reform or deindustrialization. London: Edward Elgar.

Abrahamsen, Rita (2000) Disciplining democracy. Development discourse and good governance in Africa. London: Zed Books.

Abrahamsson, Hans \& Anders Nilsson (1995) Mozambique - the troubled transition. From socialist construction to free market capitalism. London: Zed Books.

Addison, Tony, ed. (2003) From conflict to reconstruction in Africa. Oxford: Oxford University Press.

Adelman, Howard \& Astri Suhrke, eds (1999) The Rwanda crisis from Uganda to Zaire.The path of a genocide. New Brunswick: Transaction Publishers/Uppsala: Nordiska Afrikainstitutet.

Adepoju, Aderanti \& Christine Oppong, eds (1994) Gender, work \& population in sub-Saharan Africa. London: James Currey.

Adesida, Olugbenga \& Arunma O. Oteh, eds (2001) African voices - African visions. Uppsala: Nordiska Afrikainstitutet.

African Development Bank (2003) Globalization and Africa's development. African development report 2003. Oxford: Oxford University Press.

African Development Bank (2004) Africa in the global trading system. African development report 2004. Oxford: Oxford University Press.

Ajawin, Yoanes \& Alex de Waal, eds (2002) When peace comes. Civil society and development in Sudan. Lawrenceville, N.J.: The Red Sea Press.

Ayittey, George B.N. (2005). Africa unchained. The blueprint for Africa's future. London: Palgrave Macmillan.

Ake, Claude (1996) Democracy and development in Africa. Washington, D.C.: The Brooking Institution.

Ake, Claude (2000) The feasibility of democracy in Africa. Dakar: CODESRIA Books.

Alden, Chris (2001) Mozambique and the construction of the new African state. From negotiations to nation-building. London: Palgrave Macmillan.

Asmal, Kader et al. (1997) Reconciliation through truth. A reckoning of apartheid's criminal governance. Cape Town: David Philip/London: James Currey. 2 ed.

Baker, Bruce (2000) Escape from domination in Africa. Political disengagement \& its consequences. Trenton: Africa World Press/Oxford: James Currey.

Barkan, Joel D., ed. (1994) Beyond capitalism vs. socialism in Kenya \& Tanzania. Boulder/London: Lynne Rienner.

Barratt Brown, Michael (1995) Africa's choices. After thirty years of the World Bank. London: Penguin. 
Bauer, Gretchen \& Scott D. Taylor (2005) Politics in Southern Africa. State \& society in transition. Boulder/London: Lynne Rienner.

Bayart, Jean-François (1993) The state in Africa. The politics of the belly. Harlow: Longman.

Bayart, Jean-François et al. (1999) The criminalization of the state in Africa. Oxford: James Currey.

Beckman, Björn \& Lloyd Sachikonye, eds (2001) Labour regimes and liberalization. Harare: University of Zimbabwe Publications.

Bell, Terry \& Dumisa Buhle Ntsebeza (2003) Unfinished business. South Africa, apartheid and truth. London: Verso.

Belshaw, Deryke \& Ian Livingstone, eds (2002) Renewing development in subSaharan Africa. London: Routledge.

Berman, Bruce et al., eds (2004) Ethnicity \& democracy in Africa. Oxford: James Currey.

Bezdrob, Anne Marie du Preez (2003) Winnie Mandela. A life. Cape Town: Zebra Press.

Bond, Patrick \& Masimba Manyana (2002) Zimbabwe’s plunge. Exhausted nationalism, neoliberalism and the search for social justice. London: Merlin Press.

Bond, Patrick (2000) Elite transition. From apartheid to neoliberalism in South Africa. Scotsville: University of Natal Press/London: Pluto Press.

Bond, Patrick, ed. (2002) Fanon's warning. A civil society reader on the New Partnership for Africa's Development. Trenton: Africa World Press.

Bond, Patrick (2002) Unsustainable South Africa. Environment, development and social protest. Pietermaritzburg: University of Natal Press/London: Merlin.

Bond, Patrick (2003) Against global apartheid. South Africa meets the World Bank, IMF and international finance. London: Zed Books. 2. ed.

Bond, Patrick (2004) Talk left, walk right. South Africa's frustrated global reforms. Scottsville: University of Kwazulu-Natal Press/London: Merlin Press.

Bookin-Weiner, Jerome \& James A. Willner (1998) Morocco. The Arab West. Boulder/Oxford:Westview Press.

Boone, Catherine (2003) Political topographies of the African state. Territorial authority and institutional choice. Cambridge: Cambridge University Press.

Booth, David, ed. (2003) Fighting poverty in Africa. Are the PRSPs making a difference? London: Overseas Development Institute.

Brandell, Inga (1998) Algeriet. Demokratins och islamismens tid. Stockholm: Tranan.

Bratton, Michael \& Nicolas van de Walle (1997) Democratic experiments in Africa. Regime transitions in comparative perspective. Cambridge: Cambridge University Press. 
Breinholt, Tine (2001) Benin. En politisk og økonomisk oversigt. København: Danida.

Brown, William (2002) The European Union and Africa. The restructuring of North-South relations. London : I.B. Tauris.

Braathen, Einar et al., eds (2000) Ethnicity kills? The politics of war, peace and ethnicity in sub-Saharan Africa. London: Macmillan.

Bush, Ray (1999) The economic crisis and the politics of reform in Egypt. Boulder, Col./London:Westview Press.

Bush, Ray, ed. (2002) Counter-revolution in Egypt's countryside. Land and farmers in the era of economic reform. London: Zed Books.

Butler, Anthony (2004) Contemporary South Africa. Basingstoke: Palgrave Macmillan.

Bøås, Morten \& Karin Dokken (2002) Internasjonal politikk og utenrikspolitikk $i$ Afrika sør for Sahara. Oslo: Universitetsforlaget.

Campbell, Horace (2003) Reclaiming Zimbabwe. Cape Town: David Philip/Trenton: Africa World Press.

Carlsson, Jerker et al., eds (1997) Foreign aid in Africa. Learning from country experiences. Uppsala: Nordiska Afrikainstitutet.

Chabal, Patrick, ed. (1986) Political domination in Africa. Reflections on the limits of power. Cambridge: Cambridge University Press.

Chabal, Patrick (1992) Power in Africa. An essay in political interpretation.

Chabal, Patrick \& Jean-Pascal Daloz (1999) Africa works. Disorder as political instrument. Oxford: James Currey.

Chan, Stephen (2003) Robert Mugabe. A life of power and violence. London: I.B. Tauris.

Charrad, Mounira M. (2001) States and women's rights. The making of postcolonial Tunisia, Algeria, and Morocco. Berkeley: University of California Press.

Chazan, Naomi et al. (1999) Politics and society in contemporary Africa. Boulder/London: Lynne Rienner. 3. ed.

Cheru, Fantu (2002) African renaissance. Roadmaps to the challenge of globalization. London: Zed Books.

Christie, Frances \& Joseph Hanlon (2001) Mozambique \& the great flood of 2000. Oxford: James Currey.

Christie, Kenneth (2000) The South African Truth Commission. London: Palgrave Macmillan.

Clapham, Christopher (1996) Africa and the international system. The politics of state survival. Cambridge: Cambridge University Press.

Clapham, Christopher, ed. (1998) African guerillas. Oxford: James Currey.

Clark, Nancy L. \& William H. Worger (2003) South Africa. The rise and fall of apartheid. Harlow: Longman. 
Cornwall, Andrea, ed. (2005) Readings in gender in Africa. Oxford: James Currey.

Cowen, Michael \& Liisa Laakso, eds (2002) Multi-party elections in Africa. Oxford: James Currey.

Daniel, John et al., eds (1999) Voting for democracy. Watershed elections in contemporary anglophone Africa. Aldershot: Ashgate.

Darnolf, Staffan \& Liisa Laakso, eds (2003) Twenty years of independence in Zimbabwe. From liberation to authoritarianism. Basingstoke: Palgrave Macmillan.

Dashwood, Hevina S. (2000) Zimbabwe. The political economy of transformation. Toronto: University of Toronto Press.

De Vylder, Stefan et al. (2001) De minst utvecklade länderna och världshandeln. Stockholm: Sida.

De Waal, Alex (1997) Famine crimes. Politics \& the disaster relief industry in Africa. London: James Currey.

De Waal, Alex, ed. (2003) Demilitarizing the mind. African agenda for peace and security.Trenton: Africa World Press.

De Waal, Alex, ed. (2004) Islamism and its enemies in the Horn of Africa. London: C. Hurst \& Co.

Deegan, Heather (2001) The politics of the new South Africa. Apartheid and after. Harlow: Longman.

Desai, Ashwin (2002) We are the poors. Community struggles in post-apartheid Africa. NewYork: Monthly Review Press.

Deverajan, Shantayanan et al., eds (2001) Aid and reform in Africa. Lessons from ten case studies. Washington, D.C.: The World Bank.

Devereux, Stephen \& Simon Maxwell, eds (2001) Food security in sub-Saharan Africa. London: Intermediate Technology Development Group.

Diamond, Larry \& Marc F. Plattner, eds (1999) Democratization in Africa. Baltimore: The Johns Hopkins University Press.

Diener, Ingolf \& Olivier Grafe, eds (2001) Contemporary Namibia. The first landmarks of a post-apartheid society. Windhoek: Gamsberg.

Dollar, David et al., eds (2001) Aid and reform in Africa. Washington, D.C.: World Bank.

Drysdale, John (2001) Whatever happened to Somalia? London: HAAN Associates Publishing. 2. ed.

Ehnmark, Anders (1993) Resan till Kilimanjaro. Stockholm: Norstedt.

Ehnmark, Anders (1995) Resa i skuggan. Stockholm: Norstedt.

Ellis, Stephen, ed. (1996) Africa. People, politics \& institutions. London: James Currey.

Ellis, Stephen (1999) The mask of anarchy. The destruction of Liberia and the religious dimension of an African civil war. London: C. Hurst \& Co. 
Engberg-Pedersen, Poul et al., eds (1996) Limits of adjustment in Africa. The effects of economic liberalization, 1986-94. London: James Currey.

Engel, Ulf \& Gorm Rye Olsen, eds (2005) Africa and the North. Between globalization and marginalization. London: Routledge.

Englund, Harri, ed. (2002) A democracy of chameleons. Politics and culture in the new Malawi. Uppsala: Nordiska Afrikainstitutet.

Eriksen, Tore Linné (2002) Nelson Mandela. Et liv i kamp mot rasisme og undertrykking. Oslo: Omnipax.

Fahmy, Ninette S. (2002) The politics of Egypt. State-society relationship. London: Routledge Curzon.

Fellesrådet for Afrika, ed. (2000) Afrikanere om Afrika. Fellesrådets Afrika-årbok 2000-2001. Oslo: Fellesrådet for Afrika/Solidaritet Forlag.

Fellesrådet for Afrika, ed. (2002) Media i Afrika - Afrika i media. Fellesrådets Afrika-årbok 2002-2003. Oslo: Fellesrådet for Afrika/Solidaritet Forlag.

Fellesrådet for Afrika, ed. (2003) For en neve dollar. Handel med Afrikas framtid. Oslo: Fellesrådet for Afrika/Solidaritet Forlag.

French, Howard W. (2004) A continent for the taking. The tragedy and hope of Africa. New York: Knopf.

Furley, Oliver \& Roy May (2001) African interventionist states. Aldershot: Ashgate.

Garon, Lise (2003) Dangerous alliances. Civil society, the media and democratic transition in North Africa. London: Zed Books.

Geisler, Gisela (2004) Women and the remaking of politics in southern Africa. Negotiating autonomy, incorporation and representation. Uppsala: Nordiska Afrikainstitutet.

Gerner, Deborah \& Jillian Schwedler, eds (2004) Understanding the contemporary Middle East. Boulder/London: Lynne Rienner. 2. ed.

Gibbon, Peter, ed. (1993) Social change and economic reform in Africa. Uppsala: Nordiska Afrikainstitutet.

Gibbon, Peter et al. (1993) A blighted harvest. The World Bank \& African agriculture in the 1980s. London: James Currey.

Glaser, Daryl (2001) Politics and society in South Africa. London: SAGE Publications.

Glickman, Harvey, ed. (1995) Ethnic conflict and democratization in Africa. Atlanta: The African Studies Association Press.

Goetz, Anne Marie \& Shireen Hassim, eds (2003) No shortcuts to power. African women in politics and policy making. London: Zed Books.

Gordon, April A. (1996) Transforming capitalism and patriarchy. Gender and development in Africa. Boulder/London: Lynne Rienner.

Gordon, April A. \& Donald L. Gordon, eds (2002) Understanding contemporary Africa. Boulder/London: Lynne Rienner. 
Gould, St. John (2002) Morocco. Transformations and continuity. London: Routledge.

Gourevitch, Philip (1999) We wish to inform you that tomorrow we will be killed with our families. Stories from Rwanda. London: Picador.

Graybill, Lyn S. (2002) Truth and reconciliation in South Africa. Miracle or model? Boulder/London: Lynne Rienner.

Green, December (1999) Gender violence in Africa. African women's responses. New York: St. Martin's Press.

Guest, Robert (2004) The shackled continent. Power, corruption, and African lives. Washington, D.C.: Smithsoninan Books.

Hall, Margaret \& Tom Young (1997) Confronting Leviathan. Mozambique since independence. London: C. Hurst \& Co.

Hanlon, Joseph (1996) Peace without profit. How the I.M.F. blocks rebuilding in Mozambique. Oxford: James Currey.

Hansen, Holger Bernt \& Michael Twaddle, eds (1998) Developing Uganda. Oxford: James Currey.

Harrison, Graham (2002) Issues in the contemporary politics of sub-Saharan Africa. The dynamics of struggle and resistance. London: Palgrave Macmillan.

Harrison, Graham (2004) The World Bank and Africa. The construction of governance states. London: Routledge.

Havnevik, Kjell (1993) Tanzania. The limits to development from above. Uppsala: Nordiska Afrikainstitutet.

Havnevik, Kjell \& Brian van Arkadie, eds (1996) Domination or dialogue? Experiences and prospects for African development cooperation. Uppsala: Nordiska Afrikainstitutet.

Hay, Margaret Jean \& Sharon Stichter, eds (1995) African women south of the Sahara. Harlow: Longman. 2. ed.

Hayman, Rachel et al., eds (2003) The New Partnership for Africa's Development (NEPAD). Internal and external visions. Edinburgh: Centre for African Studies.

Haynes, Jeff (1996) Religion and politics in Africa. London: Zed Books.

Herbst, Jeffrey (2000) States and power in Africa. Comparative lessons in authority and control. Princeton: Princeton University Press.

Hermele, Kenneth (1996) Anpassas eller utvecklas. Skuldkrisen, Världsbanken och Sverige. Stockholm: Afrikagrupperna.

Himmelstrand, Ulf et al., eds (1994) African perspectives on development. Controversies, dilemmas and openings. London: James Currey.

Hirsch, John L. (2001) Sierra Leone. Diamonds and the struggle for democracy. Boulder/London: Lynne Rienner.

Hoeven, Rolph van der \& Fred van der Kraaj, eds (1994) Structural adjustment and beyond in sub-Saharan Africa. London: James Currey. 
Hodges, Tony (2004) Angola. Anatomy of an oil state. Oxford: James Currey. 2. ed. (1. ed., 2001: Angola from Afro-stalinism to petro-diamond capitalism.)

Holland, Martin (2002) The European Union and the Third World. Basingstoke: Palgrave.

Hopkins, Nicholas S. \& Kirsten Westergaard, eds (1998) Directions of change in rural Egypt. Cairo: The American University in Cairo Press.

Huband, Mark (2001) The skull beneath the skin. Africa after the cold war. Boulder/London: Westview Press. (Paperback 2003.)

Hughes, Stephen O. (2001) Morocco under King Hassan. Reading: Ithaca Press/Garnet Publishing.

Husain, Ishrat \& Rashid Faruquee, eds (1996) Adjustment in Africa. Lessons from country case studies. Washington, D.C.: The World Bank.

Hutchful, Eboe \& Abdoulaye Bathily, eds (1998) The military and militarism in Africa. Dakar: CODESRIA Books.

Hutchful, Eboe (2002) Ghana's adjustment experience. The paradox of reform. Oxford: James Currey.

Hydén, Göran et al., eds (2002) Media and democracy in Africa. Uppsala: Nordiska Afrikainstitutet.

Iheduru, Obioma M., ed. (2001) Contending issues in African development. Westport/London: Geenwood Press.

Ihonvbere, Julius O. (1996) Economic crisis, civil society and democratization. The case of Zambia. Trenton: Africa World Press.

Ihonvbere, Julius O. \& Timothy Shaw (1998) Illusions of power. Nigeria in transition. Trenton: Africa World Press.

Jacobs, Sean \& Richard Calland, eds (2003) Thabo Mbeki's world. The politics and ideology of the South African president. London: Zed Books.

Jespersen, Jesper (1998) Ghana. En økonomisk og politisk oversigt. København: Danida.

Joseph, Richard, ed. (1999) State, conflict, and democracy in Africa. Boulder/London: Lynne Rienner.

Juma, Monica Kathina \& Astri Suhrke, eds (2002) Eroding local capacity. International humanitarian action in Africa. Uppsala: Nordiska Afrikainstitutet.

Jönsson, Catharina \& Pia Laskar, eds (2000) Kvinnor i Namibia. Stockholm: Afrikagrupperna.

Kasfir, Nelson, ed. (1998) Civil society and democracy in Africa. Critical perspectives. London: Frank Cass.

Kayizzi-Mugerwa, Steve et al., eds (1998) Towards a new partnership with Africa. Challenges and opportunities. Uppsala: Nordiska Afrikainstitutet.

Keane, Fergal (1996) Season of blood. A Rwandan journey. London: Penguin.

King, Stephen J. (2003) Liberalization against democracy. The local politics of economic reform in Tunisia. Bloomington: Indiana University Press. 
Koigi wa Wamwere (1995) Drømmen om frihet. Oslo: Aschehoug.

Koigi wa Wamwere (2001) Etnisitetsbomben. Hvordan Afrika ødelegger seg selv. Oslo: Pax.

Koigi wa Wamwere (2002) I refuse to die. New York: Seven Stories Press.

Koigi wa Wamwere (2003) Negative ethnicity. From bias to genocide. New York: Seven Stories Press.

Konadu-Agyemang, Kwadwo, ed. (2001) IMF and World Bank sponsored structural adjustment programs in Africa. Ghana's experience 1983-1999. Aldershot: Ashgate.

Kristiansen, Tomm (1994) Mor Afrika. Oslo: Cappelen. (Paperback 1996.)

Kristiansen, Tomm (1995) I Mandelas land. En fortelling om frihet. Oslo: Cappelen.

Krog, Antjie (1998) Country of my skull. Cape Town: Random House.

Lancaster, Carol (1999) Aid to Africa. So much to do, so little done. Chicago/London: The University of Chicago Press.

Larney, Kathrine Toftkær (2001) Malawi. En politisk og økonomisk oversigt. København: Danida.

Le Vine, Victor T. (2004) Politics in Francophone Africa. Boulder/London: Lynne Rienner.

Lee, Margaret C. (2003) The political economy of regionalism in southern Africa. Boulder/London: Lynne Rienner.

Legum, Colin \& Geoffrey Mmari, eds (1995) Mwalimu. Influences of Nyerere. London: James Currey.

Legum, Colin (1999) Africa since independence. Bloomington: Indiana University Press.

Lemarchand, René (1996) Burundi. Ethnic conflict and genocide. Cambridge: Woodrow Wilson Center Press/Cambridge University Press. 2. ed.

Lewis, Peter, ed. (1998) Africa. Dilemmas of development and change. Boulder/Oxford: Westview Press.

Leys, Colin (1996) The rise \& fall of development theory. London: James Currey.

Little, Peter D. (2003) Somalia. Economy without state. Oxford: James Currey.

Lodge, Tom (2003) Politics in South Africa. From Mandela to Mbeki. Oxford: James Currey.

Long, David \& Bernard Reich, eds (2002) The government and politics of the Middle East and North Africa. Boulder/Oxford: Westview Press. 4. ed.

Lund, Christian (1997) Niger. En politisk og økonomisk oversigt. København: Danida.

Lund, Søren \& Henrik Secher Marcussen (1996) Burkina Faso. En politisk og økonomisk oversigt. København: Danida.

Lundahl, Mats, ed. (2001) From crisis to growth in Africa. London: Routledge. 
Løchstøer, Cathrine (1995) Algerie. Ved demokratiets grense. Oslo: Aschehoug.

Maier, Karl (2000) This house has fallen. Nigeria in crisis. London: Allen Lane/Penguin. (Paperback 2002.)

Mamdani, Mahmood \& Ernest Wamba-dia-Wamba, eds (1995) African studies in social movements and democracy. Dakar: CODESRIA Books.

Mamdani, Mahmood (1996) Citizen and subject. Contemporary Africa and the legacy of late colonialism. Princeton: Princeton University Press/London: James Currey.

Mamdani, Mahmood (2001) When victims become killers. Colonialism, nativism \& the genocide in Rwanda. Oxford: James Currey.

Mandela, Nelson (1994) Long walk to freedom. The autobiography of Nelson Mandela. London: Little, Brown. (Danish transl.: Vejen til frihed. København: Rosinante, 1994. Norwegian transl.: Veien til frihet. Oslo: Aschehoug, 1994. Swedish transl.: Den långa vägen till frihet. Stockholm: Rabén Prisma, 1994.)

Mandela, Nelson (2003) In his own words. From freedom to the future. London: Little, Brown.

Marais, Hein (2001) South Africa. Limits to change. The political economy of transformation. London: Zed Books. 2. ed..

Markakis, John (1998) Resource conflict in the Horn of Africa. London: Sage.

Martin, Phyllis A. \& Patrick O’Meara, eds (1995) Africa. Bloomington: Indiana University Press. 3. ed.

Mbaku, John M. \& Julius O. Ihonvbere (2003) The transition to democratic governance. Westport: Praeger

McDonald, David A. \& Eunice Njeri Sahle, eds (2002) The legacies of Julius Nyerere. Influences on development discourse and practice in Africa. Trenton: Africa World Press.

McDougall. James, ed. (2003) Nation, society and culture in North Africa. London: Frank Cass.

Melber, Henning, ed. (2000) Namibia. A decade of independence 1990-2000. Windhoek: The Namibian Economic Policy Research Unit.

Melber, Henning, ed. (2003a) Re-examining liberation in Namibia. Political cultures since independence. Uppsala: Nordiska Afrikainstitutet.

Melber, Henning, ed. (2003b) Limits to liberation in southern Africa. The unfinished business of democratic consolidation. Cape Town: HSRC Press.

Melin, Mia, ed. (1995) Democracy in Africa. On whose terms? Stockholm: Forum Syd.

Melvern, Linda R. (2000) A people betrayed. The role of the West in Rwanda's genocide. London: Zed Books.

Melvern, Linda (2004) Conspiracy to murder. Planning the Rwanda genocide. London: Verso Books. 
Mengisteab. Kidane \& B. Ikubolajeh Logan, eds (1995) Beyond economic liberalization in Africa. Structural adjustment and the alternatives. London: Zed Books.

Meredith, Martin (1997) Nelson Mandela. A biography. London: Hamish Hamilton. (Paperback Penguin, 1998.)

Meredith, Martin (1999) Coming to terms. South Africa's search for truth. New York: Public Affairs.

Meredith, Martin (2002) Mugabe. Power and plunder in Zimbabwe. Oxford: Public Affairs. (Also publ. in U.S.A.: Our votes, our guns. Robert Mugabe and the tragedy of Zimbabwe.)

Mikell, Gwendolyn, ed. (1997) African feminism. The politics of survival in subSaharan Africa. Philadelphia: Pennsylvania University Press.

Milton-Edwards, Beverly (2000) Contemporary politics in the Middle East. Oxford: Polity Press.

Mkandawire, Thandika \& Adebayo Olukoshi, eds (1995) Between liberalisation and oppression.The politics of structural adjustment in Africa. Dakar: CODESRIA Books.

Mkandawire, Thandika \& Charles Soludo (1999) Our continent, our future. African perspectives on structural adjustment. Dakar: CODESRIA Books/Trenton: Africa World Press.

Mkandawire, Thandika \& Charles Soludo, eds (2003) African voices on structural adjustment. Dakar: CODESRIA Books/Trenton: Africa World Press.

Mohan, Giles et al., eds (2000) Structural adjustment. Theory, practice and impacts. London: Routledge.

Mohan, Giles \& Tunde Zack-Williams, eds (2004) The politics of transition in Africa. Oxford: James Currey. (ROAPE African readers.)

Moore, John L. (2003) Zimbabwe's fight to the finish. The catalyst of the free market. London: Kegan Paul.

Moyo, Sam (1995) The land question in Zimbabwe. Harare: SAPES Books.

Moyo, Sam (2000) Land reform under structural adjustment in Zimbabwe. Uppsala: Nordiska Afrikainstitutet.

Mshomba, Richard E. (2000) Africa in the global economy. Boulder/London: Lynne Rienner Publisher.

Negash, Tekeste \& Lars Rudebeck, eds (1995) Dimensions of development with emphasis on Africa. Uppsala: Nordiska Afrikainstitutet.

Negash, Tekeste \& Kjetil Tronvoll (2000) Brothers at war. Making sense of the Eritrean-Ethiopian war. Oxford: James Currey.

Nielsen, Søren Walther (2000) Eritrea. En politisk og økonomisk oversigt. København: Danida.

Nnoli, Okwudiba, ed. (1998) Ethnic conflicts in Africa. Dakar: CODESRIA Books. 
Nyang'oro, Julius E., ed. (1996) Discourses on democracy. Africa in comparative perspective. Dar es Salaam: Dar es Salaam University Press.

Nyong'o, Peter Anyang et al., eds (2002) New Partnership for Africa's Development. NEPAD. A new path? Nairobi/Berlin: Heinrich Böll Foundation.

Nzongola-Ntalaja, Georges \& Margaret C. Lee, eds (1998) The state and democracy in Africa. Trenton: Africa World Press.

Ofcansky, Thomas P. (1999) Uganda. Tarnished pearl of Africa. Boulder/Oxford: Westview Press.

Okonta, Ike \& Oronto Douglas (2003) Where vultures feast. Shell, human rights, and oil in the Niger Delta. London: Verso.

Olukoshi, Adebayo O. \& Lennart Wohlgemuth, eds (1995) A road to development. Africa in the 21st century. Uppsala: Nordiska Afrikainstitutet.

Olukoshi, Adebayo O. \& Liisa Laakso, eds (1996) Challenges to the nation-state in Africa. Uppsala: Nordiska Afrikainstitutet.

Olukoshi, Adebayo O., ed. (1998) The politics of opposition in contemporary Africa. Uppsala: Nordiska Afrikainstitutet.

Osaghae, Eghosa, ed. (1994) Between state and civil society in Africa. Perspectives on development. Dakar: CODESRIA Books.

Osaghae, Eghosa E. (1998) The crippled giant. Nigeria since independence. Bloomington/Indianapolis: Indiana University Press.

Ottaway, Marina, ed. (1997) Democracy in Africa. The hard road ahead. Boulder/London: Lynne Rienner.

Owen, Roger (2004) State, power and policymaking in the making of modern Middle East. London: Routledge. 3. ed.

Palmberg, Mai (1994) Afrika. Stockholm: Natur och Kultur. (Länderböckerna.)

Palmberg, Mai \& Per Strand (1995) Sydafrika. En regnbågsnation föds. Uppsala: Nordiska Afrikainstitutet.

Palmberg, Mai, ed. (1999) National identity and democracy in Africa. Uppsala: Nordiska Afrikainstitutet.

Pankhurst, Donna (1996) A resolvable conflict? The politics of land in Namibia. Bradford: University of Bradford.

Parpart, Jane L. \& Kathleen A. Staudt, eds (1989) Women and the state in Africa. Boulder/London: Lynne Rienner.

Pausewang, Siegfried et al., eds (2002) Ethiopia since the DERG. A decade of democratic pretension and performance. London: Zed Books.

Peterson, Scott (2000) Me against my brother. At war in Somalia, Sudan and Rwanda. London: Routledge.

Pinkney, Robert (2001) The international politics of East Africa. Manchester: Manchester University Press.

Pitcher, M. Anne (2002) Transforming Mozambique. The politics of privatization, 1975-2000. Cambridge: Cambridge University Press. 
Posel, Deborah \& Graeme Simpson, eds (2002) Commissioning the past. The Truth and Reconciliation Commission. Johannesburg: Witwatersrand University Press.

Pottier, Johan (2002) Re-imagining Rwanda. Conflict, survival and disinformation in the late twentieth-century. Cambridge: Cambridge University Press.

Potts, Deborah \& Tanya Bowyer-Bower, eds (2003) Eastern and southern Africa. Development challenges in a volatile region. Harlow: Pearson Education.

Prunier, Gérard (2002) From genocide to continental war. The Congo conflict and the crisis of contemporary Africa. London: C. Hurst \& Co.

Raftopoulos, Brian \& Lloyd Sachikonye (2001) Striking back. The labour movement and the post-colonial state in Zimbabwe 1980-2000. Harare: Weaver Press.

Rakner, Lise (2003) Political and economic liberalisation in Zambia, 1991-2001. Uppsala: Nordiska Afrikainstitutet.

Reed, David (2001) Economic change, governance and natural resource wealth. The political economy of change in southern Africa. London: Earthscan.

Reigstad, Ingeborg Brenne (2002) Fri til å velge? En studie av hvordan afrikanske samfunnsforskere utfordrer vestlig liberal demokratidiskurs. [Also electronic] Oslo: Centre for Development and the Environment (SUM)/University of Oslo. http://www.digbib.uio.no/publ/statsvitenskap/2002/4162/4162.pdf.

Reno, William (1998) Warlord politics and African states. Boulder/London: Lynne Rienner.

Roberts, Hugh (2003) Battlefield Algeria, 1988-2002. Studies in a broken polity. London: Verso.

Romdane, Mahmoud Ben \& Sam Moyo, eds (2002) Peasant organizations and the democratic process in Africa. Dakar: CODESRIA Books.

Ross, Fiona C. (2003) Bearing witness. Women and the Truth and Reconciliation Commission in South Africa. London: Pluto Press.

Rubin, Barry (2002) Islamic fundamentalism in Egyptian politics. London: Palgrave Macmillan.

Rudebeck, Lars (2001) On democracy’s sustainability. Transition in Guinea-Bissau. Stockholm: Sida.

Rugumamu, Severine M. (1997) Lethal aid. The illusion of socialism and selfreliance in Tanzania. Trenton: Africa World Press.

Rye Olsen, Gorm, ed. (1994) Afrika - det ukuelige kontinent. København: Danmarks radio.

Saasa, Oliver with Jerker Carlsson (2002) Aid and poverty reduction in Zambia. Mission unaccomplished. Uppsala: Nordiska Afrikainstitutet.

Salam, A.H. Abdel \& Alex de Waal, eds (2001) The Phoenix state. Civil society and the future of Sudan. Trenton: Red Sea Press.

Salih, M.A. Mohamed \& John Markakis, eds (1998) Ethnicity and the state in eastern Africa. Uppsala: Nordiska Afrikainstitutet. 
Salih, M.A. Mohamed (2001) African democracies \& African politics. London: Pluto Press.

Salih, M.A. Mohamed, ed. (2003) African political parties. Evolution, institutionalisation and governance. London: Pluto Press.

Samatar, Abdi Ismail (1999) An African miracle. State and class leadership and colonial legacy in Botswana development. Portsmouth, NH: Heinemann.

Samatar, Abdi Ismail \& Ahmed I. Samatar, eds (2002) The African state. Portsmouth: Heinemann.

Sampson, Anthony (1999) Mandela. The authorised biography. London: HarperCollins. (Paperback 2000.) (Swedish transl.: Mandela. En biografi. Stockholm: Wahlström \& Widstrand, 2000.)

Sandbrook, Richard (2000) Closing the circle. Democratization and development in Africa. Toronto: Between the Lines/London: Zed Books.

SAPRIN - Structural Adjustment Participatory Review International Network (2004) Structural adjustment. The SAPRIN report. London: Zed Books.

Saro-Wiwa, Ken (1995) A month and a day. A detention diary. London: Penguin. (Norwegian transl.: Fengselsdagbok. Nigeria og Shell - krigen mot ogoniene. Oslo: Cappelen, 1996.)

Saul, John S. (2001) Millennial Africa. Capitalism, socialism, democracy. Trenton: Africa World Press.

Schatzberg, Michael G. (2001) Political legitimacy in Middle Africa. Father, family, food. Bloomington/Indianapolis: Indiana University Press.

Schraeder, Peter (2004) African politics and society. A mosaic in transformation. Belmont: Thomson/Wadsworth. 2. ed.

Schwab, Peter (2001) Africa. A continent self-destructs. London: Palgrave Macmillan. (Paperback 2003.)

Sichone, Owen \& Bornwell C. Chikulo, eds (1996) Democracy in Zambia. Challenges for the Third republic. Harare: SAPES Books.

Simon, David et al., eds (1995) Structurally adjusted Africa. Poverty, debt and basic needs. London: Pluto Press.

Simon, David, ed. (1998) South Africa in southern Africa. Reconfiguring the region. Oxford: James Currey.

Sisulu, Elinor (2003) Walter \& Albertina Sisulu. In our lifetime. London: Abacus.

Sjögren, Vivi-Ann (2001) Detta möte. Anteckningar från Benin. Esbo: Schildt.

Skard, Torild (2001) Mødrenes kontinent. Blant jentebruder, helbredere og barnesoldater i Vest- og Sentral-Afrika. Oslo: Pax forlag. (English transl.: Continent of mothers, continent of hope. Understanding and promoting development in Africa today. London: Zed Books, 2003.)

Smith, Charles David (2001) Ecology, civil society and the informal economy in North West Tanzania. Aldershot: Ashgate.

Smith, Malinda S., ed. (2003) Globalizing Africa. Trenton: Africa World Press. 
Sorenson, David S. (2005) The politics of the Middle East and North Africa. Harlow: Longman.

Soyinka, Wole (1996) The open sore of a continent. A personal narrative of the Nigerian crisis. New York/Oxford: Oxford University Press.

Sparks, Allister (1995) Tomorrow is another country. The inside story of South Africa's negotiated revolution. London: Heinemann. (Swedish transl.: I morgon är ett annat land. Stockholm: Norstedt, 1996.)

Sparks, Allister (2003) Beyond the miracle. The making of the new South Africa. London: Profile Books.

Stenseth, Nils Chr. et al., eds (1995) Afrika - natur, samfunn og bistand. Oslo: Ad Notam Gyldendal.

Strudsholm, Jesper (text) \& Klaus Holsting (photo) (1994) "Undskyld, hvor er den hvide kø?” 20 scener fra Sydafrikas overgang til demokrati. København: Forlaget Politisk Revy.

Suttner, Raymond (2003) Chris Hani. Portrait of a South African revolutionary. Melbourne: Ocean Press.

Söderbaum, Fredrik (2004) The political economy of regionalism. The case of southern Africa. London: Palgrave Macmillan.

Sørbø, Gunnar \& Peter Vale, eds (1997) Out of conflict. From war to peace in Africa. Uppsala: Nordiska Afrikainstitutet.

Tangri, Roger (1999) The politics of patronage in Africa. Parastatals, privatization \& private enterprise. Oxford: James Currey.

Taylor, Ian \& Paul Williams, eds (2004) Africa in international politics. External involvement on the continent. London: Routledge.

Thomas, Caroline \& Peter Wilkin, eds (1999) Globalization, human security, and the African experience. Boulder/London: Lynne Rienner.

Thomson, Alex (2004) An introduction to African politics. London: Routledge. 2. ed.

Tordoff, William (2002) Government and politics in Africa. London: Palgrave Macmillan. 4. ed.

Tripp, Aili Mari (2000) Women \& politics in Uganda. Oxford: James Currey.

Tripp, Aili Mari \& Joy C. Kwesiga, eds (2002) The women's movement in Uganda. History, challenges, and prospects. Kampala: Fountain Publishers.

Turshen, Meredith \& Clotilde Twagiramariya, eds (1998) What women do in wartime. Gender and conflict in Africa. London: Zed Books.

Tutu, Desmond (1994) The rainbow people of God. London: Doubleday. (Swedish transl.: Kampen för Sydafrikas befrielse 1976-1994. Örebro: Libris, 1995.)

Tutu, Desmond (1999) No future without forgiveness. London: Rider. (Danish transl.: Ingen fremtid uden tilgivelse. København: Rosinante, 2000. Norwegian transl.: Ingen fremtid uten tilgivelse. Oslo: Pax forlag, 2000. Swedish transl.: Ingen framtid utan förlåtelse. Stockholm: Norstedt, 2000.) 
Tvedten, Inge (1997) Angola. Struggle for peace and reconstruction. Boulder/Oxford: Westview Press.

Tygesen, Peter (2002) Congo - formoder jeg. Fortcellinger fra drømmeland. København: Centrum.

United Nations Conference on Trade and Development (1999) African development in a comparative perspective. London: James Currey.

United Nations Conference on Trade and Development (2002) Economic development in Africa. From adjustment to poverty reduction -what is new? [Elektronisk] Geneve: UNCTAD. http://www.unctad.org/en/docs//pogdsafricad 2.en.pdf.

United Nations Conference on Trade and Development (2004) Economic development in Africa. Trade performance and commodity dependence. [Electronic] Geneve: UNCTAD. http://www.unctad.org/en/docs/gdsafrica20031 en.pdf

United Nations Conference on Trade and Development (2004) Economic development in Africa. Debt sustainability - oasis or mirage? [Electronic] Geneve: UNCTAD. http://www.unctad.org/en/docs/gdsafrica20041 en.pdf

Vandewalle, Dirk (1998) Libya since independence. Oil and state-building. Ithaca, NY: Cornell University Press.

Van de Walle, Nicolas (2001) African economies and the politics of permanent crisis, 1979-1999. Cambridge: Cambridge University Press.

Van de Walle, Nicolas et al. (2004) Beyond structural adjustment. The institutional context of African development. London: Palgrave Macmillan.

Vilby, Knud (1994) Det sorte Afrika mellem håb og desperation. København: Munksgaard. (Norwegian transl.: Det svarte Afrika. Oslo: Cappelen, 1996.)

Villa-Vicencio, Charles \& Wilhelm Verwoerd, eds (2000) Looking back, reaching forward. Reflections on the Truth and Reconciliation Commission of South Africa. Cape Town: David Philip/London: Zed Books.

Villalón, Leonardo A. \& Phillip A. Huxtable, eds (1998) The African state at a critical juncture. Between disintegration \& reconfiguration. Boulder/London: Lynne Rienner.

Vilby, Knud (1997) Det sydlige Afrika i kort og tal. København: Mellemfolkeligt Samvirke.

Vilby, Knud (1999) Uganda. En politisk og økonomisk oversigt. København: Danida.

Volpi, Frederic (2002) Islam and democracy. The failure of dialogue in Algeria, 1988-2001. London: Pluto Press.

Wamwere, Koigi wa see Koigi wa Wamwere

White, Howard et al. (2001) African poverty at the millennium. Causes, complexities, and challenges. Washington, D.C.: World Bank.

Widner, Jennifer A., ed. (1994) Economic change and political liberalization in subSaharan Africa. Baltimore/London: The Johns Hopkins University Press. 
Wiseman, John A., ed. (1995) Democracy and political change in sub-Saharan Africa. London: Routledge.

Woodward, Peter (2002) The Horn of Africa. Politics and international relations. London: I.B. Tauris. 2. ed.

World Bank (1994) Adjustment in Africa. Reforms, results, and the road ahead. New York/Oxford: Oxford University Press.

World Bank (2000) Can Africa claim the 21st century?. Washington, D.C.: The World Bank.

Wright, Stephen (1998) Nigeria. Struggle for stability and status. Boulder/Oxford: Westview.

Wright, Stephen, ed. (1999) African foreign policies. Boulder/Oxford: Westview Press.

Wästberg, Per (1995) I Sydafrika. Resan mot friheten. Stockholm: Wahlström \& Widstrand.

Young, Tom, ed. (2003) Readings in African politics. Oxford: James Currey.

Zach-Williams, Tunde et al., eds (2002) Africa in crisis. New challenges and possibilities. London: Pluto Press.

Zartmann, I. William, ed. (1995) Collapsed states. The disintegration and restoration of legitimate authority. Boulder/London: Lynne Rienner.

Zeilig, Leo, ed. (2002) Class struggle and resistance in Africa. Gretton, Cheltenham: New Clarion Press.

Zeleza, Paul Tiyambe (2003) Rethinking Africa's globalization, vol. 1: The intellectual challenges. Trenton: Africa World Press.

Zewde, Bahru \& Siegfried Pausewang (2002) Ethiopia. The challenge of democracy from below. Uppsala: Nordiska Afrikainstitutet/Addis Abeba: Forum for Social Studies.

Zoubir, Yahia H. (1999) North Africa in transition. State, society, and economic transformation in the 1990s. Gainesville: University Press of Florida. 


\section{Geography}

\section{Christer Krokfors}

\section{Revised for the third edition by Peter Kinlund}

The geography of Africa is characterised by the interaction of uniformity and multiplicity. Uniformity and clarity in terms of macro general structures, and multiplicity, difference and even confusion at the micro level. This makes the continent's geography not only fascinating but also demanding when seeking geographic understanding. The task of teasing out specificities from more general patterns requires that one approaches the levels of the household and the individual. Conversely, in order to give the small-scale details some degree of universal applicability one must work on national, regional, continental and even global scales. This applies to both natural and social geographical phenomena.

With these considerations in mind, it can be said that the task of compiling a bibliographic overview of Africa's geography presents one with a number of possible approaches. One alternative is to compile a thematic bibliography where sub-sections are devoted to aspects pertaining to topography, climate, vegetation, demography, economy and politics. An alternative approach is to use regions and countries as a basis for thematic delineation. Both of these alternatives demand that one must decide whether the focus should concern, on the one hand, more encompassing factors, or, on the other hand, aspects concerning variety and difference at the micro level. Choices made at this stage will be reflected in the selection of literature to be included - monographs or case study based work. This thematic bibliography draws principally from literature of a more encompassing character, but a number of case studies that foreground local conditions have been incorporated in order to avoid a complete focus on the macro geography of Africa. This has had the unavoidable consequence that the bibliography is uneven in terms of coverage of different geographic themes and regions. It should also be pointed out that is not always immediately self-evident whether a specific work is geographic or not. For this reason this bibliography includes works which, in other contexts, could be categorised as having anthropological or historical foci. Dissertations from the geographical disciplines have in only a few cases been included. Dissertations from the Nordic countries are easily searched by using the Nordic Africa Institute's library catalogue NOAK. 


\section{General surveys}

It is well worth becoming familiar with a number of now classic reference works are well worth acquainting oneself with. One of these is without doubt Dudley Stamp's Africa. A study in tropical development which received considerable attention following it's publication in 1953. With hindsight, Stamp's work can be seen as a forerunner to the ecological studies of today. Two further definitive works were written in the contextof the initial period of de-colonisation in Africa: Kimble's (1960) Tropical Africa I-II, and Hance's (1964) The geography of modern Africa. Kimble's work resulted from discussions that took place at a number of international seminars during the late 1950s. The work is thematically organised. Part one - Land and livelihood - includes good overviews of natural geography, demographics and agriculture. Part two - Society and polity - is today of more historical interest. Two volumes edited by R. Mansell Prothero are also well worthy of note: A geography of Africa. Regional essays on fundamental characteristics, issues and problems (1973) and People and land in Africa south of the Sahara. Readings in social geography (1972).

A readable overview that includes a well balanced account of the background to the most important development processes in Africa is John M. Pritchard's (1979a) Africa. A study geography for advanced students. Instead of a more general overview, Pritchard chooses to examine a smaller number of themes in more detail. The presentation is thematic and primarily concerns itself with social geography, but natural geography and ecology are ever present in his synthesising analytical approach. The volume concludes with suggestions for more in-depth studies.

Another general work that can be recommended is A.T. Grove's now classic The changing geography of Africa (1993). The original edition of Grove's Africa published in 1967, included a thematic section and a regional section, but in later editions the regional section has given way to leave room for a deeper analysis of, amongst other aspects, ecology, diseases, pests, historical geography, demographics, development geography and crises.

Richard White's Africa in focus. A physical, human and economic geography (1998) is a straightforward, easily read but general study that is mainly written for upper-secondary school students.

An excellent volume with a strong regional focus is The changing geography of Africa and the Middle East, edited by Chapman and Baker (1992). Particularly informative is Joffé's chapter on North Africa which is one of the better written and more dynamic analyses of that region. An anthology with a pronounced regional geographic character and with a strong focus on questions pertaining to social geography that deserves mention here is Geography of sub-Saharan Africa, edited by Samuel Aryeetey-Attoh (2003). In contrast to the majority of other works presented in this bibliography, the authors of the texts included in this book come from Africa, mostly from West Africa. A further book with a firm grounding in regional 
geography is Robert Stock's textbook Africa south of the Sahara. A geographical interpretation (1995). The natural geographical content of the book is however very limited.

A volume that usefully represents French regional geography is Gourou's L'Afrique from 1970. Gourou strives towards a synthesis of natural geography, historical geography and social geography from a humanistic perspective. A comparable work in Swedish - although not primarily geographical - is Mai Palmberg's Afrika (1994) which largely deals with different identities and images of Africa.

A thematic social geographic work is Udo's The human geography of tropical Africa (1982). Following his concise introduction to Africa's natural environments, Udo examines, amongst other aspects, primary production, industrialisation, trade, and transportation. The book also includes a politicalgeography essay which examines the rise of modern African states and the influence of the slave trade on African development. The concluding chapter examines aspects relating to the struggle for national and international integration. A further volume grounded in political geography and which has a principal focus on Africa is Dixon and Hefferman's Colonialism and development in the contemporary world (1991). A very critical introduction to aspects that are more generally marshalled under the term 'rural development' is to be found in Siddle and Swindell's Rural change in tropical Africa. From colonies to nation states (1990). A central theme in this work is competition for resources.

A book that places special emphasis on unity and diversity within a thematic framework is Tropical Africa by Tony Binns (1994). Binns examines a spectrum of themes including: population distribution, the environment as a variable in development, rural and urban areas, and democratisation. The thematic presentation is augmented with detailed case studies from The Gambia, Kenya, Mali, Burkina Faso, Nigeria, Sierra Leone, Tanzania, Ghana and Zimbabwe. Another work that also serves as a useful introduction is Tropical African development. Geographical perspectives, edited by Gleave (1992).

A region of Africa that has understandably attracted considerable attention over a long period of time is southern Africa, and more particularly South Africa. A number of more general geographical books that have been published in recent years include: Fox and Rowntree (2000) The Geography of South Africa in a changing world; Lemon (1995) The Geography of change in South Africa; Lemon \& Rogerson (2002) Geography and economy in South Africa and its neighbours; Lester (1996) From colonisation to democracy. A new historical geography of South Africa; Lester et al. (2000) South Africa past, present and future. Gold at the end of the rainbow? 


\section{Introduction to natural geography}

A consummate introduction to the natural geography of Africa is The Physical geography of Africa, edited by Adams, Goudie and Orme (1996). A number of accessible textbooks that are also worthy of mention are Man's physical environment. An intermediate physical geography by the Nigerian geographers Faniran and Ojo (1980), and An introduction to the geography of the tropics by Adejuwon (1979), also from Nigeria. These are classically organised textbooks and, although their focus is not explicitly on Africa, they do include many examples from the continent.

An excellent introductory text to Africa's geomorphology is provided by Pritchard in his Landform and landscape in Africa (1979b). In addition to a traditional presentation of geomorphology from the perspective of endo- and exogenous processes, Pritchard also discusses landscape change that has been caused by factors such as deforestation, overgrazing, mining, and the alteration of water courses. A richly illustrated work concerning the geomorphology of endo- and exogenous processes is Landforms in Africa. An introduction to geomorphology by Buckle (1978).

\section{Climate}

A many-facetted work on climate is Jackson's (1989) Climate, water and agriculture in the tropics. Jackson is a specialist on East African climatology and hydrology. The links that are made with agriculture make this work of interest to those who are not strictly physical geographers. An important work which links the climate debate to the exploitation of grazing lands is Range ecology at disequilibrium, edited by Behnke, Scoones and Kerven (1993). Lauer and Frankenberg's Untersuchungen zur Humidität und Aridität in Afrika (1981) is a useful work for those who are interested in relations between land use and climate. With a point of departure in the relations between temperature, humidity and aridity, Africa is divided into so-called hygrothermal climatic regions which are summarised in the form of a very instructive map. The 'drought catastrophes' that have affected Africa have given rise to an extensive debate concerning long-term climatic change. A synthesising discussion is presented in Farmer and Wigley's Climatic trends for tropical Africa (1985). Another text that can be recommended in this area is Tyson's Climatic change and variability in southern Africa (1986). 


\section{Biogeography}

An accessible compilation of Africa's vegetation geography is White's The vegetation of Africa (1983). The text examines ecology, landuse and flora from a regional perspective. The volume also includes four vegetation maps on the scale of 1:5 000 000. A particularly fascinating work which links directly into the bio-diversity debate is Kingdon's Island Africa. The evolution of Africa's rare animals and plants (1990). This richly illustrated book portrays Africa's animal life from the perspective of the concept of 'continental islands' - isolated areas that have gained a particularly distinctive animal life over millions of years of evolution. Examples of these 'continental islands' are the Skeleton Coast in Namibia, the mountainous areas of Somalia, the delta of the River Niger, and the Ethiopian highlands. Two books that also explicitly provide information on biological diversity are The conservation atlas of tropical forests edited by Sayer et al. (1992) and The rainforests of West Africa. Ecology, threats, conservation by Martin (1991). A valuable insight into the manner in which local populations manage important wetland areas is presented in Indigenous management of wetlands. Experiences in Ethiopia by Dixon (2003). Published in the same series - SOAS Studies in Development Geography - is Global thinking and local action. Agriculture, tropical forest loss and conservation in southeast Nigeria by the Nigerian researcher Uwem Ite (2001).

\section{Environment, land and society}

Concerning the interplay between environment and society, Paul Harrison (1996) has written an introductory overview entitled The greening of Africa which, among other aspects, deals with agricultural development and the green revolution, questions concerning hunger, and the sustainable development of the continent's resources. Another book by the same author, The third revolution, expertly combines different views concerning population-environment relations and elucidates the connection with examples from, amongst other areas, Madagascar, The Ivory Coast, and Burkina Faso. A concise volume by James (1993) entitled Africa's ecology. Sustaining the biological and environmental diversity of the continent, deals with housing, commercial and subsistence farming, tourism and nature reserves in the various natural geographical zones of the continent. A special chapter deals with women's roles in the context of the sustainable utilization of Africa's resources. A gold mine of information for those who are interested in Africa's dryland regions is Human ecology in savanna environments by Harris (1980) which deals with human ecology and resource utilization among a number of other issues. Different perspectives on

desertification are collected in a thematic number of GeoJournal edited by 
Ibrahim (31:1, 1993). Particular emphasis is given to the roles of social and political factors in the desertification process. An important book which illuminates the desertification debate in a provocative manner is Thomas and Middleton's Desertification. Exploding the myth (1994).

A number of books that more specifically link environmental conditions with political developments are: Lewis and Berry (1988) African environments and resources; Falloux and Talbot (1993) Crisis and opportunity. Environment and development in Africa (southern Africa only); Hjort af Ornäs and M. Salih (1989) Ecology and politics. Environmental stress and security in Africa. The last mentioned of these books resulted from a Nordic Africa Institute research project entitled 'Human life in African arid lands'. Anderson and Grove's edited volume from 1987 entitled Conservation in Africa. People, policies and practice has become a modern classic. A further volume that deals with environmental protection but from a different perspective is Sustaining the soil. Indigenous soil and water conservation in Africa by Chris Reij et al. (1996) which includes many concrete examples highlighting local knowledge and innovation. A work that is also worthy of the term 'classic' is The lie of the land. Challenging received wisdom on the African environment edited by Leach and Mearns (1996). This is an important and compelling work which questions many of the current understandings pertaining to environmental conditions and resource utilization of local populations in Africa. In the same area of study one should also mention the Nordic Africa Institute's publication Producing nature and poverty in Africa edited by Broch-Due \& Schroeder (2000), and Politics, poverty and production in the West African Sahel, edited by Benjaminsen and Lund (2001). Another commendable book within the area of study more usually termed political ecology is Liberation ecologies. Environment, development, social movements edited by Richard Peet and Michael Watts (1996). This volume does not explicitly focus on Africa but it does include many case studies from the continent. A very accessible and recommendable book in this area of study is People and environment in Africa by Tony Binns (1995). It includes concise articles by authors who also feature in many of the above mentioned works. The book also contains texts by Tiffen who together with Mortimore and Gichuki (1994) co-authored another modern classic, More people, less erosion. Environmental recovery in Kenya. This book is a study of the Machakos region and illustrates, among other things, that population growth can lead to an improved environmental situation.

\section{Land and livelihood}

Many of the titles that have been mentioned above are also of relevance in this section. Here, it is important to mention an important classic work: Allan's The African husbandman (1977). Allan's presentation of a number of 
detailed studies provides a compelling insight into agricultural and food systems in different regions of the African continent. Paul Richards' book, Indigenous agricultural revolution. Ecology and food production in West Africa (1985) is not specifically geographical but has gained considerable recognition. Richards provides examples which illustrate the wealth of knowledge and capacity for innovation held by the African farmer. The prevailing picture of African agriculture is that of an extensive system characterised by low levels of productivity but Widgren \& Sutton's (2004) Islands of intensive agriculture in eastern Africa shows this to be a reified picture. A further work which provides important insights into the manner in which people organise resources is Mortimore \& Adams' Working the Sahel. Environment and society in northern Nigeria (1999). The same region is explored by Watts in his well-informed book Silent violence. Food, famine and peasantry in northern Nigeria (1983). Other works that deserve mention in this context are Moock (1986) Understanding Africa's rural households and farming systems, and Ellis (2000) Rural livelihoods and diversity in developing countries. An example of a more historically focused study is James McCann's Green land, brown land, black land. An environmental history of Africa, 1800-1990 (1999). The same author has also written a more detailed country based environmental history entitled People of the plow. An agricultural history of Ethiopia 1800-1990 (1995).

A work which examines people's adjustments to climatological, economic and social flux in arid areas is Adaptive strategies in African arid lands, edited by Bovin \& Manger (1990). The same research programme at the Nordic Africa Institute - 'Human Life in African Arid Lands' - also published When the grass is gone. Development intervention in African arid lands (Baxter, 1991).

Land rights and land reform are aspects that raise central geographical questions. A book which employs a wide perspective on issues concerning land rights in different regions of Africa is Evolving land rights, policy and tenure in Africa, edited by Toulmin and Quan (2000). Bassett and Crummey's Land in African agrarian systems (1993) is also a very readable work in this field of study. A work that focuses on land rights and women in Africa is Davison's Agriculture, women, and land. The African experience (1988). A good example of a book that focuses on a single country case study (Kenya) in this area of study is In land we trust. Environment, private property and constitutional change, edited by Juma \& Ojwang (1996). A further example is Land reform in Zimbabwe. Constraints and prospects, edited by Bowyer-Bower \& Stoneman (2000) published in the SOAS Studies in Development Geography series.

One of only a handful of Swedish books within this area is Jord och vatten i södra Afrika, edited by Hillevi Nilsson (1995). 


\section{Population and society}

An important contribution to the 'population question' and which was opportunely published for the 1994 UN conference on Population and Development, is the above mentioned book by Tiffen et al. (1994) with the thought provoking title More people, less erosion. Environmental recovery in Kenya. Prior to the population conference held in Cairo in 1994, Sida/Sarec and a number of international organisations collected material which was published in a three-volume work edited by Sen et al. (1994), Egerö \& Hammarskjöld (1994), and Kjellqvist (1994). A number of chapters in these volumes explore sexual and reproductive health from a geographical perspective in the context of local societal connections. Other recommended works in this area of study are Sex roles, population and development in West Africa edited by Christine Oppong (1987) and Gender, work \& population in sub-Saharan Africa edited by Aderanti Adepoju \& Christine Oppong (1994). Adepoju has also compiled Family, population and development in Africa (1997). Another recommended work within this subject area is Demographic change in sub-Saharan Africa, edited by Foote et al. (1993).

There was a similarly large number of publications within the fields of African geography and demography in the 1980s. An important incentive for this was the world fertility survey that was undertaken between 1973 and 1984 and which covered a total of 69 countries, 12 of which were African countries: Benin, The Ivory Coast, Ghana, Cameroon, Kenya, Lesotho, Morocco, Mauritania, Nigeria, Senegal, Northern Sudan, and Tunisia. The experiences and lessons learned from this survey have been compiled in Cleland and Scott's The world fertility survey. An assessment of its contribution (1987) which incorporates a vast array of basic factual material.

Concerning migration, the Nordic Africa Institute has published a detailed study of African migrations entitled The migration experience in Africa, edited by Baker and Aina (1995). A further important work in this field is International migration in and from Africa. Dimensions, challenges and prospects, edited by Aderanti Adepoju \& Thomas Hammar (1996). Another book that elucidates the complexities and diversity concerning people's mobility in Africa is Mobile Africa. Changing patterns of movements in Africa and beyond, compiled by de Bruijn et al. (2001). This book includes both general perspectives and case studies drawn from different regions of the continent.

A publication with a pronounced historical-geographic approach to population questions in Africa is Newman's The peopling of Africa. A geographic interpretation (1995). 


\section{Urbanisation}

Processes of urbanisation in Africa are considered from a global perspective in David Simon's Cities, capital and development. African cities in the world economy (1992). Urban growth is also examined in Rakodi's The urban challenge in Africa. Growth and management of its large cities (1997), and by Drakakis-Smith in Urban and regional change in southern Africa (1992). A more local perspective is to be found in Baker and Pedersen's The ruralurban interface in Africa. Expansion and adaptation (1992). Baker has also edited Rural-urban dynamics in francophone Africa (1997). While many studies on urbanisation concentrate on primary cities, an alternative focus is to be found in Small town Africa. Studies in rural-urban interaction, edited by Baker (1990). The various chapters in African cities in crisis. Managing rapid urban growth edited by Stren et al. (1989) are written from an urban planning perspective and take up case studies from Nigeria, The Ivory Coast, Zaire, Senegal, Tanzania and Sudan. Two thematic numbers of GeoJournal, both of them edited by H.-G. Bohle, deal with urban food provisioning: 'Vulnerability, hunger and famine' $(30: 2,1993)$ and 'Cities of hunger. Urban food systems in developing countries' (34:3, 1994). The majority of the examples are drawn from the African continent. A well-written case study on urban provisioning strategies is Lourenço-Lindell's doctoral thesis on Bissau, Walking the tightrope. Informal livelihoods and social networks in a West African city (2002). Also worthy of comment in this context is O'Connor's Poverty in Africa. A geographical approach (1991). Gender issues of urban processes are discussed in A place to live. Gender research on housing in Africa, edited by Ann Schlyter (1996). A fascinating historical perspective on urbanisation in Africa is presented in Anderson and Rathbone's Africa's urban past (2000).

It must be said that works which more specifically deal with urban planning in Africa are fairly few in number. One new publication that can be recommended is Ambe Njoh's Planning in contemporary Africa. The state, town planning, and society in Cameroon (2003). A work which discusses urban planning and power with a focus on questions concerning waste management in African cities is Managing the monster. Urban waste and governance in Africa, edited by Onibokun (1999).

\section{Economic life and employment}

A progressively decreasing proportion of Africa's population is employed in the agricultural sector. This is both a result of migration and the growing nonagrarian sector in rural areas. The book entitled Farewell to farms. Deagrarianisation and employment in Africa, edited by Bryceson and Jamal (1997), discusses the impact of this process in areas of welfare, the role of 
business, and national development. Geographical texts pertaining to industrialisation in Africa are surprisingly scarce. One volume that can be named, however, is Industrializing Africa. Development options and challenges for the $21^{\text {st }}$ century by Makonnen Alemayehu (2000). Another work, albeit with a pronounced economic focus, is Thomas A. Taku's Framework for industrialization in Africa (1999). An exciting account of the links between industrialisation, import substitution, agro-business, and various power structures in Nigeria is presented in The Wheat Trap by Andrae \& Beckman (1985).

Tourism is an area of interest for many geographers and a large body of work has been produced concerning many aspects of this rapidly expanding sector of the economy. Studies on tourism in Africa are, however, relatively scarce. One text that can be mentioned here is Tourism and development in Africa by Gamble (1992). An illustrative example of the case studies that have been conducted in this area is Akyeampong's Tourism and regional development in sub-Saharan Africa. A case study of Ghana's Central Region (1996).

\section{Development geography}

In the Nordic countries, development geography as a special area of research has been principally discussed in Norway and Finland. Hesselberg (1985) links up with the debate in his book The Third World in transition. The case of peasantry in Botswana. Hesselberg invests considerable effort in finding the best unit of analysis and concludes that in the context of conditions pertaining in Africa, the multi-active household constitutes the best base unit. The multi-active household is situated at the interface between selfsufficiency and the monetary economy, between the informal economy and the formal economy, and between an urban economy and a rural economy. Through his case study from Botswana, Hesselberg also demonstrates the dynamic and fruitful aspects of this analytical approach. Mabogunje in The development process. A spatial perspective (1989) largely anchors his analysis in examples drawn from the African continent, but he approaches the development problem from an entirely different angle than that employed by Hesselberg. Mabogunje mainly deals with development problems at an interstate regional level. In his world development is best achieved through rapid large-scale change. It can be said that the different analytical approaches employed by Hesselberg and Mabogunje complement each other.

A different approach to African development geography is to be found in Bell's Contemporary Africa. Development, culture and the state (1986). Bell makes what must be considered a successful attempt to write Africa's geography by combining political-economic structures with cultural values. His work is deeply influenced by the social theorist Anthony Giddens and his use of 'praxis' as a central motor in societal change. The majority of Bell's 
examples are drawn from southern Africa. A work which is a must for those interested in African 'developmental geography' is the above mentioned Silent violence. Food, famine, and peasantry in northern Nigeria by Watts (1983).

African development based in local institutions is a theme that has characterised many strategy oriented books published in the early 1990s. The geographical base, both in terms of environment and society, is the common denominator here. In Development from within. Survival in rural Africa (Taylor and Mackenzie, 1992) the authors focus their analysis on local African knowledge and initiative as an alternative to the models of development presented above. The empirical studies are from Zimbabwe, Ghana, Kenya and Tanzania.

In recent decades 'the African crisis' has increasingly become a standard turn of phrase as soon as the continent is mentioned. This has been perhaps most evident in the context of economic and political science literature, but also in geographical work. 'The poverty crisis' is examined in a concise and pedagogical fashion in O'Connor's Poverty in Africa. A geographical approach (1991). Officially recommended solutions to the 'crisis' are contrasted with locally based solutions in From feast to famine. Official cures and grassroots remedies to Africa's food crisis (Rau, 1991). A more recent work which includes geographical perspectives that can be recommended is Africa in crisis. New challenges and possibilities, edited by Zack-Williams, Frost and Thomson (2002).

As a final reference concerning studies of African geography in a wide sense of the word, we would like to mention Achebe et al. (1990) Beyond hunger in Africa. Conventional wisdom and an African vision. This is a book that challenges the all too frequent claims voiced by what may be best termed the prophets of crisis. Four Africanists, Chinua Achebe, Achola Pala Okeyo, Göran Hydén and Christopher Magadza, were asked to give their predictions for Africa in 2057. The result is four essays that present the realistic but as yet unrealised potential for development that exists among African populations and on the African continent.

\section{References}

Achebe, C. et al., eds (1990) Beyond hunger in Africa. Conventional wisdom and an African vision. London: James Currey.

Adams, W.M., A.S. Goudie \& A.R. Orme, eds (1996) The physical geography of Africa. Oxford: Oxford University Press.

Adejuwon, J. O. (1979) An introduction to the geography of the Tropics. Walton-onThames, Surrey: Nelson.

Adepoju, A., ed. (1993) The impact of structural adjustment on the population of Africa. London: James Currey. 
Adepoju, A., ed. (1997) Family, population and development in Africa. London: Zed Books.

Adepoju, A. \& C. Oppong, eds (1994) Gender, work \& population in sub-Saharan Africa. London: James Currey.

Adepoju, A. \& T. Hammar, eds (1996) International migration in and from Africa. Dimensions, challenges and prospects. Dakar: Population, Human Resources and Development in Africa (PHRDA)/Stockholm: Centre for Research in International Migration and Ethnic Relations (CEIFO).

Akyeampong, O.A. (1996) Tourism and regional development in sub-Saharan Africa. A case study of Ghana's Central Region. Stockholm: Kulturgeografiska institutionen, Stockholms universitet. (Meddelanden från Kulturgeografiska institutionen vid Stockholms universitet, 98.)

Alemayehu, M. (2000) Industrializing Africa. Development options and challenges for the 21st century. Trenton: Africa World Press.

Allan, W. (1967) The African husbandman. Westport: Greenwood Press, 1977. (First publ. London: Oliver \& Boyd, 1965.)

Anderson, D. \& R. Grove, eds (1987) Conservation in Africa. People, policies and practice. Cambridge: Cambridge University Press.

Anderson, D. \& R. Rathbone, eds (2000) Africa’s urban past. Oxford: James Currey.

Andræ, G. \& B. Beckman (1985). The wheat trap. London: Zed Books.

Aryeetey-Attoh, S., ed. (2003) Geography of sub-Saharan Africa. Upper Saddle River: Prentice Hall. 2. ed.

Baker, J. \&: T. A. Aina, eds (1995) The migration experience in Africa. Uppsala: Nordiska Afrikainstitutet.

Baker, J. \& P. O. Pedersen, eds (1992) The rural-urban interface in Africa. Expansion and adaptation. Uppsala: Nordiska Afrikainstitutet.

Baker, J., ed. (1990) Small town Africa. Studies in rural-urban interaction. Uppsala: Nordiska Afrikainstitutet.

Baker, J., ed. (1997) Rural-urban dynamics in francophone Africa. Uppsala: Nordiska Afrikainstitutet.

Bassett, T. J. \& D. E. Crummey, eds (1993) Land in African agrarian systems. Madison: University of Wisconsin Press.

Baxter, P. T., ed. (1991 ) When the grass is gone. Development intervention in African arid lands. Uppsala: Nordiska Afrikainstitutet.

Behnke, R. H., I. Scoones \& C. Kerven, eds (1993) Range ecology at disequilibrium. New models of natural variability and pastoral adaptation in African savannas. London: Overseas Development Institute.

Bell, M. (1986) Contemporary Africa. Development, culture and the state. Harlow: Longman.

Benjaminsen, T. \& C. Lund, eds (2001) Politics, poverty and production in the West African Sahel. Uppsala: Nordiska Afrikainstitutet. 
Binns, T. (1994) Tropical Africa. London: Routledge \& Kegan Paul.

Binns, T., ed. (1995) People and environment in Africa. Chichester: Wiley.

Bohle, H.-G., ed. (1993) "Vulnerability, hunger and famine”, GeoJournal, vol. 30, no.2.

Bohle, H.-G., ed. (1994) "Cities of hunger. Urban food systems in developing countries”, GeoJournal, vol. 34, no.3.

Bovin, M. \& L. Manger, eds (1990) Adaptive strategies in African arid lands. Uppsala: Nordiska Afrikainstitutet.

Bowyer-Bower, T. A. S. \& C. Stoneman (2000) Land reform in Zimbabwe. Constraints and prospects. Aldershot: Ashgate.

Broch-Due, V. \& R. A. Schroeder, eds (2000) Producing nature and poverty in Africa. Uppsala: Nordiska Afrikainstitutet.

de Bruijn, M., R. van Dijk \& D. Foeken, eds (2001) Mobile Africa. Changing patterns of movement in Africa and beyond. Leiden: Brill.

Bryceson, D. F. \& V. Jamal, eds (1997) Farewell to farms. De-agrarianisation and employment in Africa. Ashgate: Aldershot.

Buckle, C. (1978) Landforms in Africa. An introduction to geomorphology. Harlow: Longman.

Chant, S., ed. (1992) Gender and migration in developing countries. London: Belhaven Press.

Chapman, G. P. \& K. M. Baker, eds (1992) The changing geography of Africa and the Middle East. London: Routledge.

Cleland, J. \& C. Scott, eds (1987) The world fertility survey. An assessment of its contribution. Oxford : Published for ISI by Oxford University Press.

Damascene, N. J. (1990) Les fondements physiques, humains et économiques du développement du Rwanda. Ruhengeri: Editions Universitaires du Rwanda.

Darkoh, M. B. K., ed. (1992) African river basins and dryland crises. Uppsala: University, Research Programme on Environment and International Security/Addis Ababa: OSSREA.

Davison, J., ed. (1988) Agriculture, women, and land. The African experience. Boulder, Colo.: Westview Press.

Dixon, A. (2003) Indigenous management of wetlands. Experiences in Ethiopia. Aldershot: Ashgate.

Dixon, C. \& M. J. Heffernan, eds (1991) Colonialism and development in the contemporary world. London: Mansell Publishing Ltd.

Drakakis-Smith, D., ed. (1992) Urban and regional change in southern Africa. London: Routledge.

Egerö, B. \& M. Hammarskjöld, eds (1994) Understanding reproductive change. Kenya, Tamil Nadu, Punjab, Costa Rica. Lund: Lund University Press.

Ehlers, P. \& A. Witzke (1992) Somalia — bakgrund och framtid. Uppsala: Nordiska Afrikainstitutet. 
Ellis, F. (2000) Rural livelihoods and diversity in developing countries. Oxford: Oxford University Press.

Fairhead, J. \& M. Leach (1996) Misreading the African landscape. Cambridge: Cambridge University Press.

Falloux, F. \& L. M. Talbot (1993) Crisis and opportunity. Environment and development in Africa. London: Earthscan.

Faniran, A. \& O. Ojo (1980) Mans physical environment. An intermediate physical geography. London: Heinemann.

Farmer, G. \& T. M. L. Wigley (1985) Climatic trends for tropical Africa. A research report for the Overseas Development Administration. Norwich: ODA.

Foote, K. A., K. H. Hill \& L. G. Martin, eds (1993) Demographic change in subSaharan Africa. Washington, D.C.: National Academy Press.

Fox, R. \& K. Rowntree, eds (2000) The geography of South Africa in a changing world. Oxford: Oxford University Press.

Gamble, W. P. (1992) Tourism and development in Africa. London: Murray.

Gleave, M. B., ed. (1992) Tropical African development. Geographical perspectives. Harlow: Longman.

Gordon, A. A. \& D. L. Gordon, eds (2001) Understanding contemporary Africa. Boulder: Lynne Rienner.

Gourou, P. (1970) L'Afrique. Paris: Hachette.

Grove, A. T. (1993) The changing geography of Africa. Oxford: Oxford University Press. 2. ed.

Hance, W. A. (1960) The geography of modern Africa. New York: Columbia University Press. (New ed. 1975.)

Harris, D. R., ed. (1980) Human ecology in savanna environments. London: Academic Press.

Harrison, P. (1996) The greening of Africa. Breaking through in the battle for land and food. Nairobi: Academy Science Publishers. 2. ed. (1. ed. London: Earthscan, 1987.)

Harrison, P. (1992) The third revolution. Environment, population and a sustainable world. London: I. B. Tauris. (Papaerback 1993 with subtitle: Population, environment and a sustainable world.)

Hesselberg, J. (1985) The Third World in transition. The case of peasantry in Botswana. Uppsala: Nordiska Afrikainstitutet.

Hjort af Ornäs, A., ed. (1992) Security in African drylands. Research, development and policy. Uppsala: Uppsala University.

Hjort af Ornäs, A. \& M. A. Salih Mohamed, eds (1989) Ecology and politics. Environmental stress and security in Africa. Uppsala: Nordiska Afrikainstitutet.

Hutchison, R. A., ed. (1991) Fighting for survival. Insecurity, people and the environment in the Horn of Africa. Gland: International Union for Conservation of Nature and Natural Resources. 
Hydén, G., W. O. Okoth-Ogendo \& B. Olowu, eds (1999) African perspectives on governance. Trenton: Africa World Press.

Ibrahim F. N., ed. (1993) GeoJournal, vol. 31, no.1.

Ite, U.E. (2001) Global thinking and local action. Agriculture, tropical forest loss and conservation in southeast Nigeria. Aldershot: Ashgate.

Jackson, I. J. (1989) Climate, water and agriculture in the tropics. Harlow: Longman. 2. ed.

James, V. U. (1993) Africa's ecology. Sustaining the biological and environmental diversity of a continent. London: McFarland.

Juma, C. \& J. B. Ojwang, eds (1996) In land we trust. Environment, private property and constitutional change. Nairobi: Initiative Publishers/London: Zed Books.

Kimble, G. H. T. (1960) Tropical Africa, vol.1: Land and livelihood, vol. 2: Society and polity. New York: Twentieth Century Fund.

Kingdon, J. (1990) Island Africa. The evolution of Africa's rare animals and plants. London: Collins.

Kjellqvist, T., ed. (1994) The challenge of complexity. Third World perspectives on population research. Stockholm: SAREC documentation. (Conference report, 1994:1.)

Lauer, W. \& P. Frankenberg (1981) Untersuchungen zur Humidität und Aridität von Afrika. Das Konzept einer potentiellen Landschaftsverdunstung. Bonn: Dümmler. (Bonner Geographische Abhandlungen; 66.)

Leach, M \& R. Mearns, eds (1996) The lie of the land. Challenging received wisdom on the African environment. Oxford: James Currey.

Lemon, A., ed. (1995) The geography of change in South Africa. Chichester: J. Wiley.

Lemon, A. \& C. M. Rogerson, eds (2002) Geography and economy in South Africa and its neighbours. Hampshire: Ashgate.

Lester, A. (1996) From colonisation to democracy. A new historical geography of South Africa. London: I.B. Tauris.

Lester, A., E. Nel \& T. Binns (2000) South Africa. Past, present and future. Gold at the end of the rainbow. Harlow: Longman.

Lewis, L. A. \& L. Berry (1988) African environments and resources. London: Unwin Hyman.

Lourenço-Lindell, I. (2002) Walking the tight rope. Informal livelihoods and social networks in a West African city. Stockholm: Almqvist \& Wiksell International. (Stockholm studies in human geography, 9.)

Mabogunje, A. L. (1989) The development process. A spatial perspective. London: Unwin. 2. ed.

McCann, J. C. (1995) People of the plow. An agricultural history of Ethiopia 18001990. Madison: University of Wisconsin Press. 
McCann, J. C. (1999) Green land, brown land, black land. An environmental history of Africa, 1800-1990. Portsmouth: Heinemann.

Martin, C. (1991) The rainforests of West Africa. Ecology, threats, conservation. Basel: Birkhäuser.

Moock, J. L., ed. (1986) Understanding Africa's rural households and farming systems. Boulder: Westview Press.

Mountjoy, A. B. \& D. Hilling (1988) Africa.Geography and development. London: Hutchinson.

Mortimore, M. \& W. M. Adams (1999) Working the Sahel. Environment and society in Northern Nigeria. London: Routledge.

Newman, J. L. (1995) The peopling of Africa. A geographic interpretation. New Haven: Yale University Press.

Nilsson, H., ed. (1995) Jord och vatten i södra Afrika. Stockholm: Afrikagrupperna.

Njoh, A. J. (2003) Planning in contemporary Africa. The state, town planning and society in Cameroon. Aldershot: Ashgate.

O’Connor, A. M. (1991) Poverty in Africa. A geographical approach. London: Belhaven Press.

Onibokun, A. G., ed. (1999) Managing the monster. Urban waste and governance in Africa. Ottawa: International Development Research Centre.

Oppong, C., ed. (1987) Sex roles, population and development in West Africa. London: James Currey.

Palmberg, M. (1994) Afrika. Stockholm: Natur och Kultur.

Peet, R. \& M. Watts, eds (1996) Liberation ecologies. Environment, development, social movements. London: Routledge.

Pritchard, J. M. (1979) Africa. A study geography for advanced students. Harlow: Longman.

Pritchard, J. M. (1979) Landform and landscape in Africa. London: Arnold.

Prothero, R.M., ed. (1973) A geography of Africa. Regional essays on fundamental characteristics, issues and problems. London: Routledge. Rev. ed.

Prothero, R.M., ed. (1972) People and land in Africa south of the Sahara. Readings in social geography. New York: Oxford University Press.

Rakodi, C., ed. (1997) The urban challenge in Africa. Growth and management of its large cities. New York: United Nations University Press.

Rau, B. (1991) From feast to famine. Official cures and grassroots remedies to Africa's food crisis. London: Zed Books.

Reij, C., I. Scoones \& C. Toulmin, eds (1996) Sustaining the soil. Indigenous soil and water conservation in Africa. London: Earthscan.

Richards, P. (1985) Indigenous agricultural revolution. Ecology and food production in West Africa. London: Hutchinson.

Rufin, J-C. (2001) L'empire et les nouveaux barbares. Paris: J-C. Lattès. Rev. ed. 
Salih, M. A. M., ed. (2001) Local environmental change and society in Africa. Dordrecht: Kluwer Academic. 2. ed.

Samatar, A. I., ed. (1994) The Somali challenge. From catastrophe to renewal? Boulder: Lynne Rienner.

Sayer, J. A., C. S. Harcourt \& N. M. Collins, eds (1992) The conservation atlas of tropical forests. Africa. London: Macmillan.

Schlyter, A., ed. (1996) A place to live. Gender research on housing in Africa. Uppsala: Nordiska Afrikainstitutet.

Sen, G., A. Germain \& L. C. Chen, eds (1994) Population policies reconsidered. Health, empowerment, and rights. Boston: Harward University Press.

Senior, M. \& P. O. Okunrotifa (1983) A regional geography of Africa. Harlow: Longman.

Siddle, D. \& K. Swindell (1990) Rural change in tropical Africa. From colonies to nation-states. Oxford: Basil Blackwell.

Simon, D. (1992) Cities, capital, and development. African cities in the world economy. New York: Halstead Press.

Stamp L. D. \& W. T. W. Morgan (1953) Africa. A study in tropical development. London: John Wiley. (New ed. 1972.)

Stock, R. (1995) Africa south of the Sahara. A geographical interpretation. New York: Guildford Press.

Stren, R. E. \& R. R. White, eds (1989) African cities in crisis. Managing rapid urban growth. Boulder: Westview Press.

Taku, T. A. (1999) Framework for industrialization in Africa. Westport: Praeger.

Taylor, D. R. F. \& F. Mackenzie, eds (1992) Development from within. Survival in rural Africa. London: Routledge \& Kegan Paul.

Tiffen, M., M. Mortimore \& F. Gichuki (1994) More people, less erosion. Environmental recovery in Kenya. Chichester: John Wiley.

Thomas, D. S. G. \& N. J. Middleton (1994) Desertification. Exploding the myth. Chichester: Wiley.

Toulmin, C. \& J. Quan, eds (2000) Evolving land rights, policy and tenure in Africa. London: DFID/IIED/NRI.

Toulmin, C., P. L. Delville \& S. Traoré, eds (2002) The dynamics of resource tenure in West Africa. Oxford: James Currey.

Tyson, P. D. (1986) Climatic change and variability in southern Africa. Cape Town/Oxford: Oxford University Press.

Udo R. (1982) The human geography of tropical Africa. Ibadan/London: Heinemann Educational.

Watts, M. (1983) Silent violence. Food, famine, and peasantry in northern Nigeria. Berkley: University of California Press.

Weyland, P. (1993) Inside the Third World village. London: Routledge \& Kegan Paul. 
White, F. (1983) The vegetation of Africa. A descriptive memoir to accompany the UNESCO/AETFAT/UNSO vegetation map of Africa. Paris: UNESCO.

White, R. (1998) Africa in focus. A physical, human and economic geography. London: Macmillan. Rev. ed.

Widgren, M \& J.E.G. Sutton, eds (2004) Islands of intensive agriculture in eastern Africa. Oxford: James Currey.

Zack-Williams, T., D. Frost \& A. Thomson, eds (2002) Africa in crisis. New challenges and possibilities. London: Pluto Press. 


\title{
Culture and society
}

\author{
Knut G. Nustad ${ }^{1}$
}

Africa exhibits a multiplicity of different social forms and histories. From the so-called settler states, where European emigrants settled and influenced subsequent history, and where today's states have built upon colonial political institutions, to Ethiopia, which was never colonised. In other countries, such as Somalia, the state as an institution of political integration has disappeared. Such variations in state forms are also intimately associated with cultural variations. Culture can be understood in manifold ways, but the majority of anthropologists who work with the concept are in agreement that it builds on an abstraction of people's actions, values and conceptions of the world. It follows from this that culture cannot be deployed to explain state form, or be analysed apart from politics or economy. For a good introduction to the discipline of anthropology see Eriksen (1998b).

This chapter primarily sets out to explain how anthropologists have endeavoured to gain an understanding of Africa's cultural and societal variations. The literature that is introduced is not confined to the anthropological. I endeavour to provide a concise introduction to various avenues for approaching this field of study rather than to attempt any allinclusive review. The overview is for the most part historically organised, and shows how different approaches to the study of African societal forms and cultures have successively built upon each other by later approaches endeavouring to solve the failings of earlier approaches. In addition, the chapter takes up a number of important aspects relating to African societies that have been the focus of study among social scientists. Such a way of approaching this field has meant that I have limited the discussion to a number of particular approaches rather than to attempt to cover the entire spectrum of approaches.

\section{Overview literature}

There are many overview works about culture and societal forms in Africa. In Norwegian there is Fjern og naer, edited by Howell and Melhuus (1996), which includes contributions from all regions of the world. Contributions in this book which specifically concern Africa include: 'Afrikas Horn' (Dahl 1996); 'Det sörlige Afrika’ (Gulbrandsen 1996a); 'Öst-Afrika og det sörlige

\footnotetext{
${ }^{1}$ This chapter is based on Bernhard Helander's chapter entitled 'Anthropology' published in the 1995 edition of this book. Many thanks to Tore Linné Eriksen and Aud Talle for their comments and literature recommendations and to Kristina Rylander for her assistance with literature searches.
} 
Sentralafrika' (Simonsen and Talle 1996) and 'Vestafrika' (Pedersen 1996). This is a good introduction for those who are new to the region. Africa and the disciplines edited by Bates, Mudimbe and O’Barr (1993) provides a more penetrating analysis, as does Sally Falk Moore's Anthropology and Africa. Changing perspectives on a changing theme (1994). One of the best abridged volumes to have been published in recent years is Grinker and Steiner's (1997) edited collection of articles in Perspectives on Africa. A reader in culture, history and representation. The volume is a compilation of classic texts covering a wide spectrum of themes from the traditional 'tribal studies', to colonialism, gender, nationalism, debates about rationalities, as well as articles concerning the more recent interest in representation, i.e. the representations of Africa that social scientists produce through their accounts.

\section{Classic monographs}

There is still much to be learned from the now classic anthropological studies on African society that were produced from the end of the 1930s onwards, and gaining at least an insight into this literature is certainly recommended. The discipline of social anthropology developed in a more sociological direction at the same time as there was a reorientation of focus away from Melanesia and towards Africa. Instead of concerning themselves with long and detailed descriptions of all aspects of a studied society, anthropologists now began to study important aspects of specific social groups. EvansPritchard's Witchcraft, oracles and magic among the Azande from 1937, retains its position as a classic for the manner in which it shows how phenomena such as witchcraft and magic first become meaningful when they are described with reference to the context in which they occur, instead of being interpreted from the standpoint of the observer. Evans-Pritchard's The Nuer from 1940, showed how a large ethnic group such as the Nuer could function as an integrated political group without having a centralised state. For a follow up study of the Nuer see Hutchinson (1996). Further classic works that have examined the social organisation of African societies and which conducted comparative studies of different societies, include Radcliffe-Brown and Forde's African systems of kinship and marriage (1950), and the important work from 1940 by Fortes and Evans-Pritchard entitled African political systems, which presented a typology of African forms of governance based on the presence/absence of a state and segmented kinship systems. The study of aspects concerning law represents another classic field of anthropological inquiry, and a good point of departure is Sally Falk Moore's Law as Process (2000).

The majority of the studies dating from this period focused, nevertheless, on individual societies, and endeavoured to demonstrate how social structures were upheld over time (Fortes 1949, Schapera 1940, Abrahams 1967). This approach to was also to constitute the foundation for later studies of African 
societies and cultures. More recently, these studies have been criticised for their failure to capture the processes of change that were taking place at the time of their writing, particularly in terms of colonial rule. More recent studies that are based on the classic tradition but which also endeavour to incorporate change include Beidelman (1986) and Manger (1994). Holmqvist \& Talle's Barheidas fjärde hustru (1995) illustrates how one can gain an insight into a culture and a social formation by situating a family at the centre of the narrative (see also Holmqvist \& Talle 1978). Work on a follow-up to these studies is currently in progress. The series of classics published by James Currey can be recommended for those readers who are interested in this type of study.

\section{The Manchester School}

The so-called Manchester School broke with earlier approaches used for describing African societies. The Rhodes Livingstone Institute set out to study what they understood as African industrialisation on the Zambian Copperbelt (Gluckman 1961). In order to study a society undergoing rapid transformation it was considered necessary to develop new research methods. Modern African urban societies were to be studied precisely as modern societies, and not as traditional societies in the process of being destroyed by modernity. Gluckman, for example, (1958) [1949] $]^{2}$ took as his point of departure a social situation, in this particular case the opening of a bridge in Zululand, and saw social structure as arising from the interplay between workers (labourers), missionaries, and colonial personnel (civil servants). In this manner he incorporated the contemporary period into the analysis instead of looking for an original pre-colonial African culture. This method was subsequently to be used by Mitchell in The Kalela dance (1956) and was further developed as the so-called extended case study, where the analysis departed from a specific situation instead of endeavouring to capture society as an integrated whole (Epstein 1967, Mitchell 1970, Van Velsen 1967). Many advances in the study of African societies that are employed today take these studies as their point of departure, including the study of ethnicity as situated and negotiated identity (Mitchell 1974, Epstein 1978), in network analyses (Mitchell 1969, Kapferer 1972) and in the study of the contemporary political situation. For a more recent work that builds explicitly on this approach, see Hansen's Keeping House in Lusaka (1997). Ørnulf Gulbrandsen's Poverty in the midst of plenty (1996b) is another good example of the use of ethnography in the study of macro-economic processes, as is also Hansen's study of aid organizations, second-hand clothing and identity (2000). James Ferguson's Expectations of Modernity (1999) takes issue with the dichotomous conceptualisation of rural and urban Africa that

\footnotetext{
2 This essay was first published in Bantu Studies in 1940.
} 
he claims was prevalent in these studies, and at the same time provides a good overview of the literature. Rakner (2003) has written about political and economic reforms in Zambia between 1991 and 2001. More recent publications concerning urban Africa include Baker (1997) and Hansen \& Vaa (2004).

\section{Systems of thought and world views}

Both the classic monographers and the Manchester School were engaged with culture understood as systems of thought and conceptions of the world. Classic studies such as Middleton's study of Lugbara religion (1960) and Lienhardt's Divinity and experience (1961) about Dinka religion, were founded on a holistic approach to the study of religion in African societies, as was also the case with Evans-Pritchard's Nuer Religion (1956). Victor Turner, himself a member of the Manchester School, was engaged with how rituals could maintain continuity throughout periods of conflict and change. His Schism and continuity in an African society (1957) and The forest of symbols (1967) remain classics to this day. Mary Douglas has provided important contributions to the debate on conceptions of witchcraft (1970) and classification (1966). The study of rituals has been a common approach used to gain insights into perceptions of reality, and Turner's The ritual process (1969) and Bloch's From blessing to violence (1986) are important contributions in this field. A more recent contribution is by Bovin (2001). In recent years it has become common to try to avoid totalising accounts of culture by instead utilising life histories to relate perceptions of reality. Crapanzano's Tuhami, portrait of a Moroccan (1980) is one such attempt in this vein. Adam Ashfort has recently used the same approach in his account of witchcraft, where he analyses a person's experience of being bewitched (2000). A good anthology on witchcraft and magic is Moore \& Sanders' Magical interpretations, material realities (2001). The Comaroff's have edited a volume that shows the relevance of rituals and power in contemporary Africa (1993). Maia Green (2003) raises a central theme within the study of religion in her study of the manner in which missions melded with other belief systems to generate new world views. An analogous study in the context of Ghana is by Greene (2002). The ways in which people cope with difficult and uncertain environments are well described by Whyte (1997).

African religion is an extensive field of study, but two books that provide a starting point from which to begin to traverse this field are Mbiti's Introduction to African religions (1991) and Ray's African religions. Symbol, ritual and community (2000). Bierschenk \& Stauth (2002) have edited an introductory work on Islam in Africa. African philosophy is another extensive field of study. For a good introduction see the anthology African philosophy (Brown 2004), Coetzee's The African philosophy reader (2003), 
and Wiredu's A companion to African philosophy (2004). Other useful introductions to this field are by Mbiti (1990), Bell (2002), Eze (1998), Hallen (2002), and Mosley (1995).

\section{Economy and politics}

The study of economy in African societies include the early studies such as A.I. Richards' Land, labour and diet in Northern Rhodesia (1939), and studies of African economic systems such as Bohannan \& Bohannan's Tiv Economy (1968). Bohannan \& Dalton's Markets in Africa (1962) is a good anthology of classic studies of market systems. Anthropologists later turned their attention to labour migration (Murray 1981) and process of economic change (Hill 1998, Shipton 1989). Hart's study of economic strategies in Accra (1973) gave rise to the concept of the informal economy (see also Hart 1985, 1992). Guyer (1995) provides a good overview of how understandings of economy and money are culturally situated, and how different economic systems alter when they entangle with each other. Associational life in African cities edited by Tostensen et al. (2001) is a good anthology of articles concerning popular organisation and which broadens the concept of informality to also encompass political organisation.

HIV and AIDS are in the process of assuming catastrophic proportions in many African countries. Useful anthologies in this field include HIV and AIDS in Africa by Kalipeni et al. (2004) and Irwin et al. (2003). For a short introduction see Usdin's The no nonsense guide to HIV / AIDS (2003). A good overview of the situation in Tanzania, including the causal factors for the spread of the virus among young people, is provided by Klepp et al. (1995). Much of this literature examines the efforts that have been made to prevent the spread of HIV and AIDS (Campbell 2003, Baylies \& Bujra 2000), and the social problems caused by the epidemic (Guest 2003, Jaffrey 2002).

Aud Talle's Om kvinneleg omskjaering (2003) is an exceptionally lucid commentary on the problematics surrounding the subject of circumcision. While the book chiefly approaches the problems that arise when this practice is exported, it also emphasises the importance of situating the phenomenon of circumcision within a cultural context. Arnfred (2004) has edited an anthology that, in addition to circumcision, takes up discourses concerning sexuality in Africa.

\section{Colonialism and nationalism}

While the Manchester School initiated the focus on the colonial reality in which they found themselves, a large number of other studies have been 
concerned with colonialism more generally. Walter Rodney's How Europe underdeveloped Africa (1972) is a classic in this field. Terence Ranger's chapter entitled 'The invention of tradition in colonial Africa' (1983) shows how Europeans, in their efforts to locate African institutions upon which they could build colonial rule, essentially invented an African tradition to serve the aims of colonial power. Crais' account of how British colonial power gained a foothold in South Africa in The politics of evil (2002), is a shining example of how history and ethnography can be employed to account for the expansion of colonial state control. Mamdani's Citizen and Subject. Contemporary Africa and the legacy of late colonialism (1996) similarly shows how so-called indirect rule, a form of rule employed in some territories by colonial power, was to be of profound consequence for independent states. Moore \& Vaughan have documented changing agricultural practice in Zambia over a period of one hundred years (1994).

Many studies have also described the growth of nationalism and resistance movements. Fanon's The wretched of the earth (1965) is a classic text, as is Berman's study of the Mau Mau uprising (1991). Lan’s Guns \& rain. Guerrillas \& spirit mediums in Zimbabwe (1985) illustrated how Marxist guerrillas in Zimbabwe gained support among the local population through their understanding of land and time honoured traditions. Eriksen's Common denominators (1998a) is a more recent study that examines identity, ethnicity and nationalism in Mauritius. An important work of note here is Ifi Amadiume's study of class and international aid organizations (1997, 2000). Geisler (2004) has written a history of women's anti-colonial struggle in Southern Africa.

\section{Africa and international politics}

Considerable attention has been focused on the African crisis and its causes. While books such as Hart's The political economy of West African agriculture (1982) deal with how the interplay between West Africa and the rest of the world has given rise to today's difficult situation, other books such as Bayart's The state in Africa. The politics of the belly (1993) have focused on how African states have been formed by their orientation towards, dependency upon, and exploitation of the international system and development assistance (see also Bayart et al. 1999). In the same vein, Chabal \& Daloz have argued in Africa works. Disorder as a political instrument (1999) that African states must be understood on their own terms. In a similar fashion, Monga (1998) argues that political activism cannot be analysed outside of local context.

Famine has also been the focus of a considerable body of research (De Waal 1989, Shipton 1990). De Waal (1997) argues that the international aid system is hindering the development of political institutions capable of averting future famine catastrophes. Ferguson's The anti-politics machine. 
'Development', depoliticization, and bureaucratic power in Lesotho (1990) has been the progenitor of a large number of books that draw on Michel Foucault to demonstrate how an understanding of the African crisis as a problem of development has led to the political causes of the problem to be overlooked. Earlier critiques of development assistance include Hill's Development economics on trial. The anthropological case for a prosecution (1986). Peter's Dividing the commons (1994) is an excellent study from Botswana. In their edited anthology Anderson \& Broch-Due (1999) show that the problem of poverty among pastoralists is considerably more complex than international assistance organisations believe. Saugestad's The inconvenient indigenous (2001) is an example of a successful integrative analysis of the relationship between the autochthonous population of Botswana and the international system.

The situation of autochthonous populations is a major field of study. A recommended point of entry is Lee \& Daly's edited anthology from 1999. Good individual studies include Gordon \& Sholto-Douglas (1999), Lee (2003), and Barnard (1994). Shostak's (1981) book which focuses on the life of Nisa, a !kung woman, attracted considerable interest upon its publication. She has also carried out a follow-up study (Shostak 2000).

\section{Representation}

Many Africanist social scientists have more recently concerned themselves with the manner in which anthropologists, missionaries and others have represented Africa. This has elevated the question of representation to a central position in the field of African studies. Jean and John Comaroff have, in a large number of studies, illustrated how missionaries working among the Tswana were complicit in the creation of Africans' perceptions of reality such that the latter could operate within the colonial system of administration, while at the same time also introducing the very ideas that constituted the breeding ground for resistance and liberation movements (Comaroff \& Comaroff 1986, 1988, 1991, 1997). For a similar but alternative contribution from Kilimanjaro, see Hasu (1999). Mudimbe's The idea of Africa (1994) and his earlier work The invention of Africa (1988), are important contributions here. Mudimbe has also edited a volume that provides an excellent introduction to his own perspective (Mudimbe 1997). Rigby (1996) shows how many North American and European representations of Africa have been characterised by a racial predisposition in their very advocation of equality. Eriksson Baaz \& Palmberg (2001) have edited a collection of articles about how African identities have been represented in the realms of tourism, film, art etc. The manner in which Europeans bestow attributes of athleticism upon the Tutsi is engagingly related by Bale (2002). Also worthy of mention here is Palmberg's (2001) edited anthology about representations of Africa. Palmberg \& Kirkegaard (2002) have also edited a collection of 
articles that focus on identity and music in contemporary Africa. A more accessible read is Benjaminsen \& Berges Timbuktu. Myter, mennesker, miljo (2002) which discusses European representations.

\section{References}

Abrahams, R. G. (1967) The peoples of Greater Unyamwezi, Tanzania: Nyamwezi, Sukuma, Sumbwa, Kimbu, Konongo. London: International African Institute.

Amadiume, I. (2000) Daughters of the goddess, daughters of imperialism. African women struggle for culture, power and democracy. London: Zed Books.

Amadiume, I. (1997) Re-inventing Africa. Matriarchy, religion and culture. London: Zed Books.

Anderson, D. M \& V.Broch-Due (1999) The poor are not us. Poverty and pastoralism in eastern Africa. Oxford: James Currey.

Arnfred, S., ed. (2003) Re-thinking sexualities in Africa. Uppsala: Nordiska Afrikainstitutet.

Ashforth, A. (2000) Madumo. A man bewitched. Chicago: University of Chicago Press.

Baker, J., ed. (1997) Rural-urban dynamics in Francophone Africa. Uppsala: Nordiska Afrikainstitutet.

Bale, J. (2002) Imagined olympians. Body culture and colonial representation in Rwanda. Minneapolis: University of Minnesota Press.

Barnard, A. (1994) Kalahari Bushmen. Oxford: Raintree Publishers.

Bates, R. H., V. Y. Mudimbe \& J. O'Barr (1993) Africa and the disciplines. Chicago: University of Chicago Press.

Bayart, J.-F. (1993) The state in Africa. The politics of the belly. London: Longman.

Bayart, J.-F., S. Ellis \& B. Hibou (1999) The criminalization of the state in Africa. Oxford: James Currey.

Baylies, C. \& J. M. Bujra, eds (2000) Aids, sexuality and gender in Africa. Collective strategies and struggles in Tanzania and Zambia. London: Routledge.

Beidelman, T. O. (1986) Moral imagination in Kaguru modes of thought. Bloomington: Indiana University Press. (New ed. Washington, D.C.: Smithsonian Institution Press, 1993.)

Bell, R. H. (2002) Understanding African philosophy. A cross-cultural approach to classical and contemporary issues in Africa. London: Routledge.

Benjaminsen, T. A., G. Berge \& R. Eilertsen (2000) Timbuktu. Myter, mennesker, miljø. Oslo: Spartakus.

Berman, B. J. (1991) "Nationalism, ethnicity, and modernity. The paradox of Mau Mau", Canadian Journal of African Studies, vol. 25, no. 2, pp. 181-206. 
Bierschenk, T. \& G. Stauth, eds (2002) Islam in Africa Hamburg: Lit Verlag.

Bloch, M. (1986) From blessing to violence. History and ideology in the circumcision ritual of the Merina of Madagascar. Cambridge: Cambridge University Press.

Bohannan, P. \& L. Bohannan (1968) Tiv economy. Harlow: Longman.

Bohannan, P. \& G. Dalton, eds (1962) Markets in Africa. Evanston: Northwestern University Press.

Bovin, M. (2001) Nomads who cultivate beauty. Wodaabe dances and visual arts in Niger. Uppsala: Nordiska Afrikainstitutet.

Brown, L. M. (2004) African philosophy. New and traditional perspectives. Oxford: Oxford University Press.

Campbell, C. (2003) "Letting them die". Why HIV/Aids intervention programmes fail. Oxford: James Currey.

Chabal, P. \& J.-P. Daloz (1999) Africa works. Disorder as political instrument. Oxford: James Currey.

Coetzee, P. H. \& A. P. J Roux, eds (2003) African philosophy reader. London: Routledge. 2. ed.

Comaroff, J. \& J. Comaroff (1986) "Christianity and colonialism in South Africa", American Ethnologist, vol. 13, no. 1, pp. 1-22.

Comaroff, J. \& J. Comaroff (1988) "Through the looking-glass. Colonial encounters of the first kind", Journal of Historical Sociology, vol. 1, no. 1, pp. 6-32.

Comaroff, J. \& J. Comaroff (1991) Of revelation and revolution, vol. 1: Christianity, colonialism and consciousness in South Africa. Chicago: University of Chicago Press.

Comaroff, J. \& J. Comaroff, eds (1993) Modernity and its malcontents. Ritual and power in postcolonial Africa. Chicago: University of Chicago Press.

Comaroff, J. \& J. Comaroff (1997) Of revelation and revolution, vol. 2: The dialectics of modernity on a South African frontier. Chicago: University of Chicago Press.

Crais, C. (2002) The politics of evil. Magic, state power, and the political imagination in South Africa. Cambridge: Cambridge University Press.

Crapanzano, V. (1980) Tuhami. Portrait of a Moroccan. Chicago: University of Chicago Press.

Dahl, G. (2001) "Afrikas Horn" in Fjern og næer. Sosialantropologiske perspektiver på verdens samfunn og kulturer, S. Howell \& M. Melhuus, eds, Oslo: Gyldendal Akademisk, pp. 105-126.

De Waal, A. (1997) Famine crimes. Politics \& the disaster relief industry in Africa. Oxford: James Currey.

De Waal, A. (1989) Famine that kills. Darfur, Sudan, 1984-1985. Oxford: Clarendon Press. 
Douglas, M. (1966) Purity and danger. An analysis of concepts of pollution and taboo. London: Routledge \& Kegan Paul. (New ed. New York: Routledge, 2002. Norwegian transl.: Rent og urent. Oslo: Pax, 1997. Swedish transl.: Renhet och fara. Nora: Nya Doxa, 1997.)

Douglas, M., ed. (1970) Witchcraft. Confessions \& accusations. London: Tavistock Publications.

Epstein, A. L. (1967) "The case method in the field of law" in The craft of social anthropology, A. L. Epstein, ed., Tavistock Publications, London, pp. 205-230. (New ed. Oxford: Pergamon Press, 1979.)

Epstein, A. L. (1978) Ethos and identity. Three studies in ethnicity. London: Tavistock Publications.

Eriksen, T. H. (1998a) Common denominators. Ethnicity, nation-building and compromise in Mauritius. Oxford: Berg.

Eriksen, T. H. (1998b) Små steder - store spørsmål. En innføring i sosialantropologi Oslo: Universitetsforlaget. 2. ed. (Swedish ed.: Små platser stora frågor. Nora: Nya Doxa, 2000.)

Eriksson Baaz, M.. \& M. Palmberg, eds (2001) Same and other. Negotiating African identity in cultural production. Uppsala: Nordiska Afrikainstitutet.

Evans-Pritchard, E. E. (1956) Nuer religion. Oxford: Clarendon Press. (New ed. New York: Oxford University Press, 1974.)

Evans-Pritchard, E. E. (1937) Witchcraft, oracles, and magic among the Azande. Oxford: Clarendon Press. (New ed. 1977.)

Evans-Pritchard, E. E. (1940) The Nuer. A description of the modes of livelihood and political institutions of a Nilotic people. Oxford: Clarendon Press. (New ed. New York: Oxford University Press, 1987.)

Eze, E.C., ed. (1998) African philosophy. An anthology. Oxford: Blackwell.

Fanon, F. (1965) The wretched of the earth. New York: Grove Press. (Paperback Harmondsworth: Penguin, 2001.)

Ferguson, J. (1990) The anti-politics machine. "Development", depoliticization, and bureaucratic power in Lesotho. Cambridge: Cambridge University Press.

Ferguson, J. (1999) Expectations of modernity. Myths and meanings of urban life on the Zambian Copperbelt. Berkeley: University of California Press.

Fortes, M. \& E. E. Evans-Pritchard, eds (1940) African political systems. London: Oxford University Press for the International African Institute. (New ed. London: KPI in assoc. with International African Institute, 1987.)

Fortes, M. (1949) The web of kinship among the Tallensi. The second part of an analysis of the social structure of a Trans-Volta tribe. Oosterhout:

Anthropological Publications. (New ed. 1967.)

Geisler, G. (2004) Women and the remaking of politics in southern Africa. Negotiating autonomy, incorporation and representation. Uppsala: Nordiska Afrikainstitutet. 
Gluckman, M. (1958) Analysis of a social situation in modern Zululand. Manchester: Manchester University Press.

Gluckman, M. (1961) "Anthropological problems arising from the African industrial revolution" in Social change in modern Africa. Studies presented and discussed at the first international African seminar, Makerere College, Kampala, January 1959, A. Southall, ed., London: Oxford University Press, pp. 67-82.

Gordon, R. J. \& Sholto-Douglas, S. (1999) The Bushman myth. Making of a Namibian underclass. Boulder: Westview Press. 2. ed.

Green, M. (2003) Priests, witches and power. Popular christianity after mission in southern Tanzania. Cambridge: Cambridge University Press.

Greene, S. E. (2002) Sacred sites and the colonial encounter. A history of meaning and memory in Ghana. Bloomington: Indiana University Press.

Grinker, R. R. \& Steiner, C. B., eds (1997) Perspectives on Africa. A reader in culture, history, and representation. Oxford: Blackwell.

Guest, E. (2003) Children of AIDS. Africa's orphan crisis. London: Pluto.

Gulbrandsen, Ø. (2001) "Det sørlige Afrika" in Fjern og nær. Sosialantropologiske perspektiver på verdens samfunn og kulturer, S. Howell \& M. Melhuus, eds, Oslo: Gyldendal Akademisk, pp. 127-154.

Gulbrandsen, Ø. (1996) Poverty in the midst of plenty. Socio-economic marginalization, ecological deterioration and political stability in Tswana society. Bergen: Norse publications.

Guyer, J.I., ed. (1995) Money matters. Instability, values and social payments in the modern history of West African communities. Portsmouth: Heinemann.

Hallen, B. (2002) A short history of African philosophy. Bloomington: Indiana University Press.

Hansen, K. T. (1997) Keeping house in Lusaka. New York: Columbia University Press.

Hansen, K. T. (2000) Salaula. The world of secondhand clothing and Zambia. Chicago: University of Chicago Press.

Hansen, K. T. \& Vaa, M. (2004) Reconsidering informality. Perspectives from urban Africa. Uppsala: Nordiska Afrikainstitutet.

Hasu, P. (1999) Desire and death. History through ritual practice in Kilimanjaro. Helsinki: Finnish Anthropological Society. (Transactions of the Finnish Anthropological Society, 42.)

Hart, K. (1973) "Informal income opportunities and urban employment in Ghana", Journal of Modern African Studies, vol. 11, no. 1, pp. 61-89.

Hart, K. (1982) The political economy of West African agriculture. Cambridge: Cambridge University Press.

Hart, K. (1985) "The informal economy", Cambridge Anthropology, vol. 10, no. 2, pp. 54-58. 
Hart, K. (1992) "Market and state after the cold war. The informal economy reconsidered" in Contesting markets. Analyses of ideology, discourse and practice, R. Dilley, ed., Edinburgh: Edinburgh University Press.

Hill, P. (1998) The migrant cocoa-farmers of Southern Ghana. A study in rural capitalism. Oxford: James Currey.

Hill, P. (1986) Development economics on trial. The anthropological case for a prosecution. Cambridge: Cambridge University Press.

Holmqvist, S. \& Talle, A. (1995) Barheidas fjärde hustru. Stockholm: Carlsson.

Holmqvist, S. \& Talle, A. (1978) Barheidas tre hustrur. Stockholm: LiberFörlag.

Howell, S. \& Melhuus, M. (2001) Fjern og næer. Sosialantropologiske perspektiver på verdens samfunn og kulturer. Oslo: Gyldendal Akademisk.

Hutchinson, S. E. (1996) Nuer dilemmas. Coping with money, war and the state. Berkeley: University of California Press.

Irwin, A., J. Millen \& D. Fallows (2003) Global AIDS - myths and facts. Tools for fighting the AIDS pandemic. Cambridge, Mass.: South End Press.

Jaffrey, Z. (2002) The new apartheid. AIDS in South Africa.London: Verso.

Kalipeni, E. et al. (2004) HIV and AIDS in Africa. Beyond epidemiology. Oxford: Blackwell.

Kapferer, B. (1972) Strategy and transaction in an African factory. African workers and Indian management in a Zambian town. Manchester: Manchester University Press.

Klepp, K.-I., P. M. Biswalo \& A. Talle, eds (1995) Young people at risk. Fighting AIDS in northern Tanzania. Oslo: Scandinavian University Press.

Lan, D. (1985) Guns \& rain. Guerillas \& spirit mediums in Zimbabwe. London: James Currey.

Lee, R. B. (2003) The Dobe Ju/'hoansi. Belmont: Wadsworth Thomson Learning. 3. ed.

Lee, R. B. \& Daly, R., eds (1999) The Cambridge encyclopedia of hunters and gatherers. Cambridge: Cambridge UP.

Lienhardt, R. G. (1961) Divinity and experience. The religion of the Dinka. Oxford: Clarendon Press. (New ed. 1988.)

Malkki, L. H. (1995) Purity and exile. Violence, memory and national cosmology among Hutu refugees in Tanzania. Chicago: University of Chicago Press.

Mamdani, M. (1996) Citizen and subject. Contemporary Africa and the legacy of late colonialism. Princeton: Princeton University Press.

Manger, L. O. (1994) From the mountains to the plains. Uppsala: Nordiska Afrikainstitutet.

Mbiti, J. S. (1990) African religions \& philosophy. Oxford: Heinemann 2. ed.

Mbiti, J. S. (1991) Introduction to African religion. Oxford: Heinemann 2. ed. 
Middleton, J. (1960) Lugbara religion. Ritual and authority among an East African people. London: International African Institute/Oxford University Press. (New ed. 1971.)

Mitchell, J. C. (1956) The Kalela dance. Aspects of social relationships among urban Africans in Northern Rhodesia. Manchester: Manchester University Press.

Mitchell, J. C., ed. (1969) Social networks in urban situations. Manchester: Manchester University Press.

Mitchell, J. C. (1970) "Tribe and social change in South Central Africa. A situational approach", Journal of Asian and African Studies, vol. 5, no. 1-2, pp. 83-101.

Mitchell, J. C. (1974) "Perceptions of ethnicity and ethnic behaviour. An empirical exploration" in Urban ethnicity, A. Cohen, ed., Tavistock Publications, London.

Monga, C. (1998) The anthropology of anger. Civil society and democracy in Africa. Boulder: Lynne Rienner

Moore, H. L. \& T. Sanders (2001) Magical interpretations, material realities. Modernity, witchcraft and the occult in postcolonial Africa. London: Routledge.

Moore, H. L.. \& M. Vaughan (1994) Cutting down trees. Gender, nutrition, and agricultural change in the Northern Province of Zambia. Portsmouth: Heinemann.

Moore, S. F. (1994) Anthropology and Africa. Changing perspectives on a changing scene. Charlottesville: University Press of Virginia.

Moore, S. F. (2000) Law as process. An anthropological approach. Hamburg: LIT Verlag. 2. ed.

Mosley, A. G. (1995) African philosophy. Selected readings. Englewood Cliffs: Prentice Hall.

Mudimbe, V. Y., ed. (1997) Nations, identities, cultures. Durham: Duke University Press.

Mudimbe, V. Y. (1988) The invention of Africa. Gnosis, philosophy, and the order of knowledge. Bloomington: Indiana University Press.

Mudimbe, V. Y. (1994) The idea of Africa. Bloomington: Indiana University Press.

Murray, C. (1981) Families divided. The impact of migrant labour in Lesotho. Cambridge: Cambridge University Press.

Palmberg, M., ed. (2001) Encounter images in the meetings between Africa and Europe. Uppsala: Nordiska Afrikainstitutet.

Palmberg, M. \& A. Kirkegaard, eds (2002) Playing with identities in contemporary music in Africa. Uppsala: Nordiska Afrikainstitutet.

Pedersen, J. (2001) "Vest-Afrika" in Fjern og nær. Sosialantropologiske perspektiver på verdens samfunn og kulturer, S. Howell \& M. Melhuus, eds, Oslo: Gyldendal Akademisk, pp. 181-202.

Peters, P. E. (1994) Dividing the commons. Politics, policy and culture in Botswana. Charlottesville: University of Virginia Press. 
Radcliffe-Brown, A. R. \& D. Forde (1950) African systems of kinship and marriage. International African Institute/Oxford University Press, London. (New ed. London: KIP in assoc. with International African Institute, 1987.)

Rakner, L. (2003) Political and economic liberalisation in Zambia 1991 - 2001. Uppsala: Nordiska Afrikainstitutet.

Ranger, T. (1983) "The invention of tradition in colonial Africa" in The invention of tradition, E. Hobsbawm \& T. Ranger, eds, Cambridge: Cambridge University Press. (New ed. 1992.)

Ray, B.C. (2000) African religions. Symbol, ritual, and community. Upper Saddle River: Prentice Hall. 2. ed.

Richards, A. I. (1939) Land, labour and diet in Northern Rhodesia. An economic study of the Bemba tribe. London: International African Institute/Oxford University Press.

Rigby, P. (1996) African images. Racism and the end of anthropology. Oxford: Berg.

Rodney, W. (1972) How Europe underdeveloped Africa. London: BogleL'Ouverture. (New ed . 1988.)

Saugestad, S. (2001) The inconvenient indigenous. Remote area development in Botswana, donor assistance, and the first people of the Kalahari. Uppsala: Nordiska Afrikainstitutet.

Schapera, I. (1940) Married life in an African tribe. London: Faber \& Faber. (New ed. 1971.)

Shipton, P. (1990) "African famines and food security. Anthropological perspectives", Annual Review of Anthropology, vol. 19.

Shipton, P. (1989) Bitter money. Cultural economy and some African meanings of forbidden commodities. Washington, D. C.: American Anthropological Association.

Shostak, M. (1981) Nisa. Cambridge, Mass.: Harvard University Press. (New ed. London: Earthscan, 1990.)

Shostak, M. (2000) Return to Nisa. Cambridge, Mass.: Harvard University Press.

Simonsen, J. K. \& Talle, A. (2001) "Øst-Afrika og det sørlige Sentral-Afrika" in Fjern og nær. Sosialantropologiske perspektiver på verdens samfunn og kulturer, S. Howell \& M. Melhuus, eds, Oslo: Gyldendal Akademisk, pp. 155-180.

Talle, A. (2003) Om kvinneleg omskjæring. Debatt og erfaring. Oslo: Det Norske Samlaget.

Tostensen, A., I. Tvedten \& M. Vaa, eds (2001) Associational life in African cities. Uppsala: Nordiska Afrikainstitutet.

Turner, V. (1957) Schism and continuity in an African society. A study of Ndembu village life. Manchester: Manchester University Press on behalf of the Institute for African Studies, University of Zambia. (New ed. Oxford: Berg, 1996.)

Turner, V. (1967) The forest of symbols. Aspects of Ndembu ritual.Ithaka: Cornell University Press. 
Turner, V. (1969) The ritual process. Structure and anti-structure.The Lewis Henry Morgan Lectures - 1966, presented at the University of Rochester. London: Routledge \& Kegan Paul New ed. 1995 New York : Aldine de Gruyter

Usdin, S. (2003) The no nonsense guide to HIV / Aids.London: Verso Books.

Van Velsen, J. (1967) "The extended-case method and situational analysis" in The craft of social anthropology, A. L. Epstein, ed., London: Tavistock Publications, pp. 129-149. (New ed. Oxford: Pergamon Press, 1979.)

Whyte, S. R. (1997) Questioning misfortune. The pragmatics of uncertainty in eastern Uganda. Cambridge: Cambridge University Press.

Wiredu, K., ed. (2004) A companion to African philosophy. Malden, Mass.: Blackwell. 


\section{Schools and education}

\section{Ingemar Gustafsson}

In the following presentation Africa denotes sub-Saharan Africa. A short article that sets out to present different points of entry for research into such an extensive topic must, even with this defined scope, seek to explicate common characteristics and questions. What it can not do is cover the diversity in the literature concerning specific countries.

Certain themes and perspectives reoccur in the debate concerning education and school reform and the role of development co-operation. These are similarly mirrored in the existing analytical literature. A large proportion of this material has been generated in conjunction with development cooperation and is situated at the interface of research, evaluation, and investigatory study. All three types of material do, however, constitute important sources of knowledge for those wishing to learn more about education in Africa, its history, problems, and reform efforts. With this background in mind, it is, as a rule, easier to find source material that employs a systems approach to education (i.e. sources that analyse more encompassing policy interventions, structures and priorities) than is the case for material that prioritises the perspective of the individual pupil, teacher or family.

\section{The colonial legacy}

This analytical perspective toward the material is partly to be understood against the background of colonial history and the tensions relating to the introduction and further dissemination of formal systems of education in Africa. Questions recur in many contexts concerning the tensions between the European system of education and the indigenous forms of education that had evolved in African societies. The colonial system of education mirrored the priorities and ideologies of colonial power and the church, and was one element of an international movement. The pre-colonial forms of education in African societies, on the other hand, mirrored the cultural and linguistic diversity of the African continent.

Like all societies, African societies had developed their own methods for passing knowledge, experiences and values from one generation to the next. In its European guise, however, the school constituted a departure in its distinction between the inherited and the external. The aims and the role of education have been understood in some analyses as a question of the traditional vis à vis the modern, and in others as a question of the cultural and 
political dominance of a dominating power that utilised education as a technique of control (Carnoy 1977).

Irrespective of the specific interpretative approach being used, it can be said that even prior to independence the formal system of education was already linked in various ways to the metropole through the examination system, curricula content, and books. The European system and the university were gradually opened up for a small growing African elite (King 1971, Jones 1925, University of Oslo 1993- ).

The historical perspective also encompasses studies that have sought to elucidate the tensions surrounding the existence of the two systems of education that evolved during the colonial era. This polarisation was especially apparent in the context of the post-1920 British colonial world and gave rise to what remains an ongoing debate (Murray 1967, Foster 1965a, Foster 1965b, Gustafsson 1987). On the one hand there was a system of education for a small state sector manned by colonial civil servants that was gradually opened up to a small African elite, and, on the other hand, a private system of education for the vast majority. The latter was run by various churches and employed a model based on the anticipated needs of what was conceived of as being a fairly static African peasant society.

\section{Liberation movements as milieus for pedagogic innovation}

Liberation movements in southern Africa often also constituted milieus for experimental pedagogic reform. The education that was made available to members and refugees was also to form the foundation of new national systems of education. This was equally the case for Amilcar Cabral's PAIGC in Guinea-Bissau as it was for ZANU's camps located in Mozambique. The existing teacher training education in Namibia is the result of an experiment that was initiated in SWAPO's Kwanzu Zul camp in Angola prior to Namibian independence (Dahlström 2002). This is an interesting field of research and while some research has been carried out, much remains to be done. Indeed, the period immediately following independence can be said to have been one of innovative experimentation in many countries and the influence of this on inherited systems of education constitutes an interesting research question in its own right.

\section{Nation building and economic development}

The reform efforts implemented since independence have, as a rule, concerned two guiding principles. The first has been that education should contribute to the building of a new nation-state. The second has been that 
education should contribute to economic development, i.e. be an instrument in the modernisation of economic life.

National agendas for reform have both concerned coming to terms with the colonial legacy and establishing modern systems of education founded on home-gown national curricula, teacher training courses, and educational teaching material. This also paved the way for the inception of political initiatives by independent states to provide comprehensive education for all. An interesting example here concerns the Nyerere era in Tanzania during the 1970s, when efforts were made to provide all adults and children with comprehensive education. The period immediately following independence can be more generally characterised as having been one of re-appraisal and experimentation. Zimbabwe underwent such a period of reform at the beginning of the 1980s and this included the introduction of new teacher training programmes, new textbooks and teaching aids in natural science subjects, and efforts to combine theory and practice by introducing practical work into the curriculum. In South Africa, the education system has been entirely reconfigured and democratised through the introduction of new policy, legislation and organisation. As has been discussed above, elements of the reform efforts have drawn inspiration from the experiences gained in the anti-apartheid struggle, but also derive from the ideological stance of the new government.

These developments are reflected in the pedagogic research that has been conducted on aspects relating to teacher training, the development of curricula, and, to a lesser extent, on aspects pertaining to adult education and vocational training for younger adults (King 1977 and 1996). In the case of many countries during this period, the planning process has proceeded with the needs of the economy and the employment market firmly to the fore. The problem has been seen in terms of adjusting both the size and the direction of the educational system to meet these requirements. This also had the consequence that the economics of education became a growing discipline at this time, not least in studies carried out by the World Bank. In can also be added that during the 1960s and 70s, this situation was just as relevant at the international level as it was for Africa (Psacharopoulos \& Woodhall 1985).

\section{Crises and globalisation}

The 1980s and 1990s were to be a period marked by economic crises and increasing globalisation. The growing international discourse on education and globalisation once again placed education in Africa in an international context (Samoff 1993 and 1994). Democratisation and conflict in many African countries have been interpreted as denoting a tension between the local and the global perspectives and with a weakened state situated between these two poles (World Bank 1988, Brock-Utne 1995, Carnoy 1999). 
The language question was to return to the debate with renewed vigour, as did questions concerning the education's basic values and role in establishing norms (IDRC 1997).

The possibility and potential for reform in Africa, as well as its place in an international perspective, have also again become important questions. Of central importance here is the possibility for all children in Africa to be provided with education, as well as the crisis affecting higher education. Another vital question concerns the state of education in countries that are currently experiencing crises or which are endeavouring to build up their education systems in the aftermath of armed conflict. Rwanda and Burundi are apt examples in this regard (UNESCO 2002).

Questions relating to the manner in which education should be financed and the role of the state are again important. In the period immediately following independence, the point of departure in the process of nation building was that the state should both run and finance education systems. In the wake of crises and structural adjustment, however, tuition fees and private sector alternatives have been widely introduced. Teachers have sought alternative means of provisioning and paid private tuition has expanded significantly. In certain countries parents have turned their backs on the public education system and have instead set up or turned to private alternatives. There has also been an upswing in the prevalence of Koran schools in many countries.

Crises have also affected university education. This has concerned not only the availability of resources, but also the autonomy and function of universities. In the period following independence, the point of departure for national governments was that the primary function of universities should be to contribute to the (consolidation of the) new national state. Today, new questions have arisen concerning the autonomy of higher education and research (Association of African Universities \& World Bank 1997, NORRAG 2001, Atchoarena \& Esquieu 2002).

Questions relating to the consequences of the HIV/AIDS epidemic are assuming a level of importance that is yet to be mirrored in education related research. A certain amount of material is however available (UNAIDS 2002).

\section{Education of women}

International political initiatives for gender equality have also been reflected in the debate concerning education in Africa. Perhaps the most important regional initiative was instigated at the beginning of the 1990s by a group of female Ministers of Education and researchers. A working group was established within the framework of the Association for the Development of Education in Africa and several years later an independent foundation called the Forum of African Women Educationalists (FAWE) was established. This foundation, which now has national chapters in more than 30 African 
countries, represents a rich source of knowledge on matters concerning the lack of equal rights for boys and girls, and on what can be achieved by influencing public opinion and starting strategic initiatives (FAWE 2001).

\section{The role of development co-operation}

The role and potential of development co-operation is a recurring theme in material and literature dating from the period of independence up to the present day. Aspirations and interventions aimed at reform are intimately related to external assistance. What contributions can external assistance provide? What roles can, and will, the various actors have? What role has been played by the World Bank? These are important questions that have been examined in books, articles and reports (King \& Buchert 1999).

A network of African Ministers of Education and development assistance agencies was established at the end of the 1980s as a forum for conducting dialogue about educational reform in Africa. It was originally called Donors to African Education (DAE) but is now called the Association for the Development of Education in Africa (ADEA). A number of working groups were established, one of which focuses on female participation in teaching (FAWE 2001). Interesting material concerning this and a range of other questions is to be found within the framework of ADEA. ADEA has also carried out an inventory and an analysis of the so-called sectoral studies (230 in all) of education systems in various countries, which were commissioned by a range of donor organisations during the 1980s and the beginning of the 1990s. Analyses of African experiences of reform initiatives are also available (ADEA 2001). One working group has concerned itself with questions concerning the roles of higher education and universities. This group now has its base in The Association of African Universities (AAU).

Much of the work that has been carried out has been written by external researchers or by international agencies. There is, however, a burgeoning research tradition in a number of African countries concerning the field of education, and one which is often linked to processes of national reform. As a prime example in this context, one can mention the Education Policy Units that came into existence at four South African universities at the beginning of the 1990s. Their findings subsequently formed the basis for the democratisation of the education system following apartheid (see, for example, Chakane 2002).

\section{Concluding remarks}

The above discussion has shown how a wide spectrum of disciplines has provided important approaches and points of departure for understanding education in Africa. The historical perspective is important and is to be found as a component of missionary and colonial history. Education as culture and 
as influencing culture is a central theme in the social anthropological tradition. Studies that examine education as a technique of European cultural and language domination also exist, and these often draw inspiration from the dependency school's theoretical framework. Research on language and on matters pertaining to language concern pedagogy, but is just as often discussed as a tension between the traditional and the growing modern society, between the demands of the unitary state and the cultural and linguistic diversity of traditional societies.

Questions concerning the economics of education and educational funding have risen to prominence, both as a result of the expansion of education systems after independence and in the context of economic crises.

Pedagogical research has also been conducted on questions relating to course curricula, textbooks and teaching aids, and teacher training. A basis of knowledge has been built up during recent years relating to the reasons why pupils and students terminate their schooling or have to repeat certain grades, and about what can be done to achieve equality between boys and girls.

It can also be pointed out that during the 1980s and at the beginning of the 1990s, Sida co-operated with a number of education researchers in Sweden with the goal of developing research and analytical capacity in both Guinea-Bissau and Mozambique. This support was directed to stimulate research into the pedagogical process surrounding questions such as parents' expectations of education, and the gap between existing course curricula, the contents of textbooks and the frames of reference and understanding among pupils and students. This research co-operation was initiated in order to at least partially redress the otherwise sweeping regional and national systems perspective that continues to dominate in the material (Daun 1992, Ahlenhed et al.1991, Palme 1993).

\section{References}

ADEA (2001) What works and what's new in education. Africa speaks. Paris: Association for the Development of Education in Africa.

Ahlenhed, B. et al (1991) Career in lower primary education in Guinea-Bissau. Stockholm: Sida. (Education Division documents, 54.)

Association of African Universities and the World Bank (1997) Revitalizing universities in Africa. Strategy and guidelines. Washington, D.C.: World Bank.

Atchoarena, D. \& P. Esquieu (2002) Private technical and vocational education in sub-Saharan Africa. Paris: IIEP.

Brock-Utne, B. ed. (1995) States or markets? Neo-liberalism in the educational policies of sub-Saharan Africa. Oslo: University of Oslo, Institute for Educational Research. 
Carnoy, M. (1977) Education as cultural imperialism. New York/London: Longman.

Carnoy, M. (1999) Globalization and educational reform. What planners need to know. Paris: IIEP. (Fundamentals of educational planning, 63.)

Chakane, M. (2002) "Restructuring higher education systems in South Africa. Voices of students missing in the debates", Quarterly Review of Education \& Training in South Africa, vol. 9, no. 3, pp. 1-28.

Dahlström, L. (2002) Post-apartheid teacher education reform in Namibia. The struggle between common sense and good sense. Umeå: Umeå university, Department of Education.

Daun, H. (1992) Childhood learning and adult life. The functions of indigenous, Islamic and western education in an African context. Stockholm: Institute of International Education. (Studies in comparative and international education, 24.)

FAWE (2001) Annual Report. Nairobi: Forum of African Women Educationalists.

Foster, P. (1965a) Education and social change in Ghana. Chicago: Chicago University Press.

Foster, P. (1965b) "The vocational school fallacy” in C.A. Andersson \& M.J. Bowman, eds Education and economic development. Chicago: Aldine Publishing.

Gustafsson, I. (1987) Schools and the transformation of work. A comparative study of four productive work programmes in southern Africa. Stockholm: Institute of International Education. (Studies in comparative and international education, 10.)

IDRC (1997) Languages of instruction. Policy implications for education in Africa. Ottawa: International Development Research Centre.

Jones, T. J. (1925) Education in East Africa. A study of East, Central and South Africa by the Second African Education Commission. New York: Phelps Stokes Fund.

King, K. (1971) Pan-Africanism and education. A study of race, philantropy and education in the southern states of America and East Africa. Oxford: Clarendon Press.

King, K. (1977) The African artisan. Education and the informal sector in Kenya. London: Heinemann Educational.

King, K. (1996) Jua Kali Kenya. Change and development in an informal economy. London: James Currey.

King, K. \& Buchert, L. (1999) Changing international aid to education. Global patterns and national contexts. Paris: UNESCO.

Murray, V. (1967) The school in the bush. A critical study of the theory and practice of native education in Africa. London: Frank Cass.

NORRAG (2001) NORRAG news, vols. 28 and 29. Edinburgh: Centre for African Studies.

Palme, M. (1993) The meaning of school repetition and drop-out in the the Mozambican primary school. Sockholm: Sida. (Education Division documents, 60.) 
Psacharopoulos, G. \& M. Woodhall (1985) Education for development. An analysis of investment choices. New York: Oxford University Press.

Samoff. J. (1993) “The reconstruction of schooling in Africa”, Comparative Education Review, vol. 37, no. 2, pp. 181-222.

Samoff, J. ed. (1994) Coping with crisis. Austerity, adjustment and human resources. London: Cassel/Paris: UNESCO.

UNAIDS Interagency Task Team on Education (2002) HIV/Aids \& education. Paris: IIEP.

UNESCO (2002) Education for all. Is the world on track? Paris: UNESCO.

University of Oslo (1993-) Education in Africa. Oslo: University of Oslo, Institute for Educational Research.

World Bank (1988) Education in sub-Saharan Africa. Policies for adjustment, revitalization, and expansion. Washington, D.C.: World Bank. 


\section{About the authors}

Tore Linné Eriksen, historian, Associate Professor at Oslo University College.

Ingemar Gustafsson, advisor, Sida.

Katarina Hjortsäter, librarian at the Nordic Africa Institute.

Birgitte Jansen, librarian at the Nordic Africa Institute.

Peter Kinlund, cultural anthropologist, Senior Lecturer at Stockholm University.

Christer Krokfors, cultural anthropologist, Lecturer at Uppsala University.

António Lourenço, librarian at the Nordic Africa Institute.

Åsa Lund Moberg, librarian at the Nordic Africa Institute.

Knut G. Nustad, social anthropologist, Associate Professor at the University of Oslo.

Kristina Rylander, librarian at the Nordic Africa Institute. 